Doktori (Ph.D.) értekezés

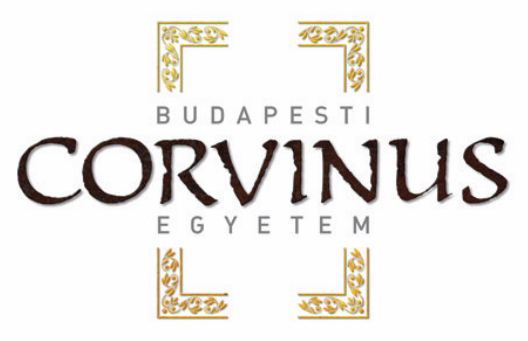

\title{
A SZŐLŐ MOLEKULÁRIS NEMESÍTÉSE HASZNOS GÉNKONSTRUKCIÓK FELHASZNÁLÁSÁVAL
}

\section{Zok Anikó}

Kertészettudományi Doktori Iskola

Budapesti Corvinus Egyetem

Genetika és Növénynemesítés Tanszék

Budapest

2013 


\author{
A doktori iskola \\ megnevezése: Kertészettudományi Doktori Iskola \\ tudományága: Növénytermesztési és kertészeti tudományok \\ vezetője: $\quad$ Dr. Tóth Magdolna \\ egyetemi tanár, DSc \\ BCE, Kertészettudományi Kar, \\ Gyümölcstermő Növények Tanszék \\ Témavezetők: Dr. Pedryc Andrzej \\ egyetemi tanár, DSc \\ Dr. Oláh Róbert \\ egyetemi docens, $\mathrm{PhD}$ \\ BCE, Kertészettudományi Kar \\ Genetika és Növénynemesítés Tanszék
}

A jelölt a Budapesti Corvinus Egyetem Doktori Szabályzatában elöírt valamennyi feltételnek eleget tett, az értekezés mühelyvitájában elhangzott észrevételeket és javaslatokat az értekezés átdolgozásakor figyelembe vette, ezért az értekezés nyilvános vitára bocsátható.

Dr. Tóth Magdolna

Dr. Pedryc Andrzej

Dr. Oláh Róbert

A doktori iskola-vezető jóváhagyása

A témavezetők jóváhagyása 
A Budapesti Corvinus Egyetem Élettudományi Területi Doktori Tanácsának 2012.12.04.-i határozatában a nyilvános vita lefolytatására az alábbi bíráló Bizottságot jelölte ki:

\title{
BÍRÁLÓ BIZOTTSÁG:
}

Elnöke

Palkovics László, DSc

\author{
Tagjai \\ Kozma Pál, CSc \\ Kocsis László, DSc \\ Korbuly János, PhD \\ Deák Tamás, PhD
}

Opponensek

Mészáros Annamária, PhD

Bisztray György, PhD

Titkár

Deák Tamás, PhD 


\section{Tartalomjegyzék}

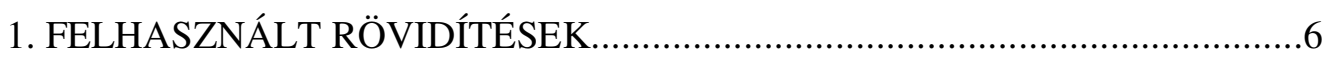

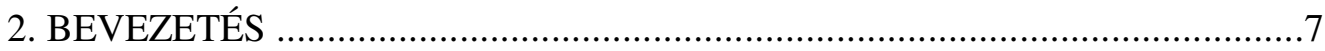

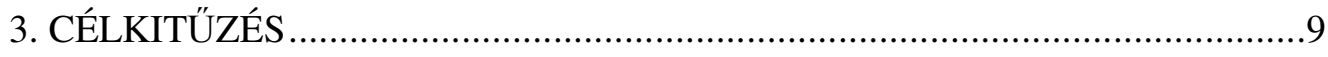

4. IRODALMI ÁTTEKINTÉS ….............................................................

4.1. A regenerációs módszerek történeti áttekintése .......................................11

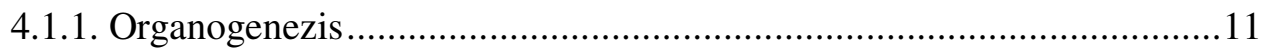

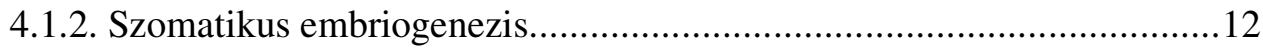

4.2. A szőlőregenerációs kísérletek eredményei...............................................13

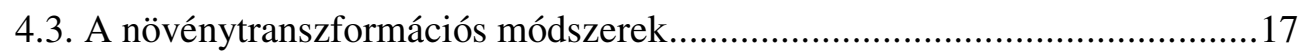

4.4. Az Agrobacterium mint transzformációs vektor .......................................20

4.5. A szőlő genetikai transzformációjának eredményei....................................24

4.6. A növényi stressztürőképesség fokozásának lehetőségei ...........................26

4.7. Agrobacterium rezisztens transzgénikus növények...................................30

4.8. Az in vitro körülmények és az akklimatizáció hatékonysága közötti

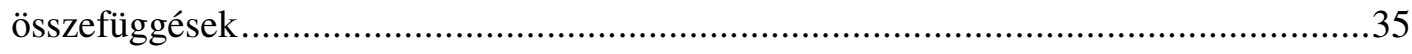

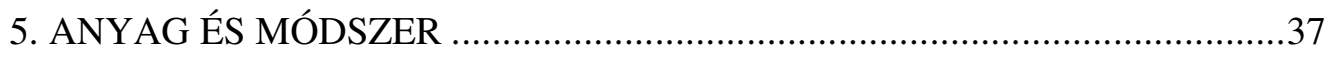

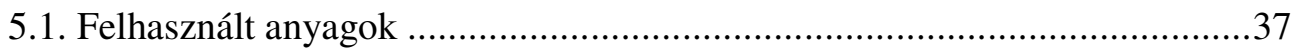

5.1.1. Felhasznált növények ............................................................... 37

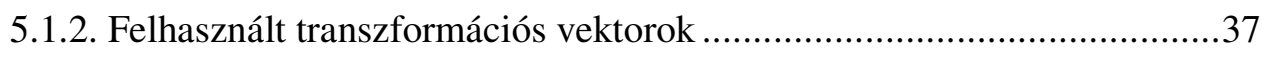

5.1.3. A transzformációs vektorok ismertetése..............................................37

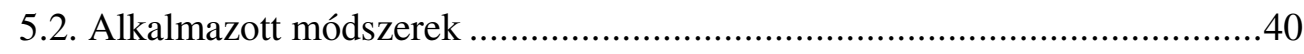

5.2.1. Embriogén kallusz indukció ........................................................40

5.2.2. Az embriogén kallusz felszaporítása ..............................................43

5.2.3. Szomatikus embrió indukció és növényregeneráció .............................44

5.2.3.1. A növényregenerációs kísérletek optimalizálása .............................44

5.2.4. Szőlő direkt organogenezis .............................................................44

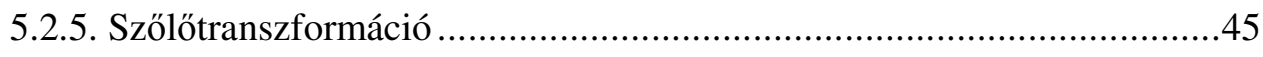

5.2.5.1. Embrió fejlődés indukálása és agrobaktériumos kezelés .................45

5.2.5.2. Az Agrobacterium elölése .........................................................46 
5.2.5.3. Növényregeneráció szelekciós táptalajon 46

5.2.5.4. A szőlőtranszformáció az MsFerr, iaaM és virE1 gének felhasználásával .46

5.2.5.5. A transzformációs kísérletek optimalizálása .................................47

5.2.6. Akklimatizációs kísérletek..................................................................48

5.2.7. A beépített DNS jelenlétének ellenőrzése PCR analízissel ...................50

5.2.8. A transzformánsok oxidatív stressztürő képességének vizsgálata ...........52

5.2.9. Agrobacterium rezisztencia vizsgálatok ............................................54

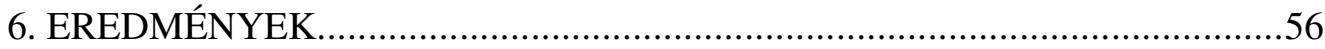

6.1. Embriogén kallusz indukálása portokon................................................56

6.2. Embriogén kallusz felszaporítása ..........................................................58

6.3. Növényregeneráció embriogén kalluszból...............................................60

6.3.1. A növényregeneráció hatékonyságának optimalizálása .......................60

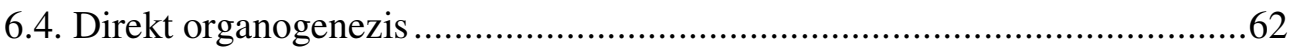

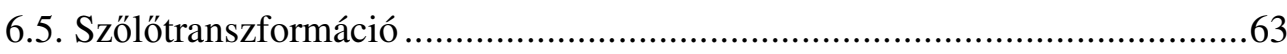

6.5.1. A transzformációs kísérletek optimalizálása ....................................65

6.6. Az akklimatizációs kísérletek eredményei.................................................67

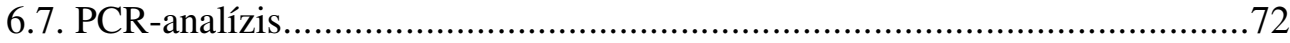

6.8. A transzformánsok oxidatív stressztürö képességének tesztelése..................75

6.9. Agrobacterium rezisztencia vizsgálatok ..................................................78

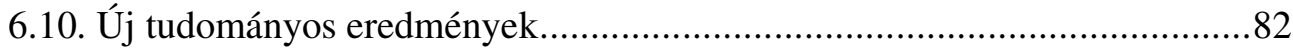

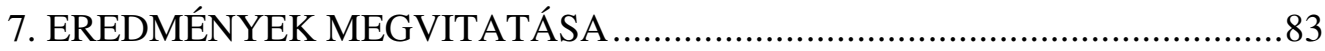

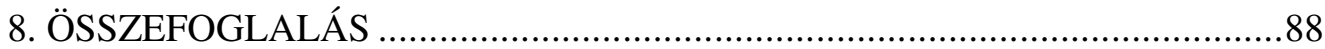

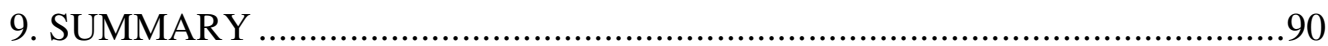

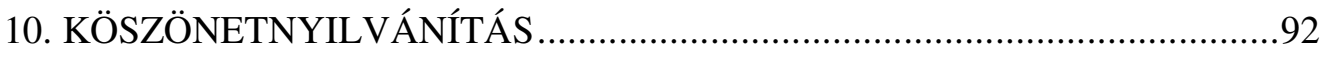

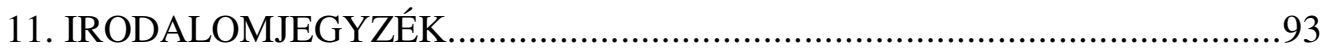




\section{FELHASZNÁLT RÖVIDÍTÉSEK}

$\begin{array}{ll}2,4-D & \text { 2,4-diklórfenoxi-ecetsav } \\ \text { BA } & \text { benzil-adenin } \\ \text { CaMV } & \text { karfiol mozaik vírus } \\ \text { CP } & \text { Cheé és Pool (1987) által leírt táptalaj } \\ \text { DTE } & \text { dithioerythritol } \\ \text { GA } & \text { gibberrelinsav } \\ \text { gus } & \text { B-glükoronidáz gén } \\ \text { IAA } & \text { indol-3-ecetsav } \\ \text { iaaH } & \text { indol-3-acetamid hidroláz gén } \\ \text { iaaM } & \text { triptofán-monooxigenáz gén } \\ \text { ipt } & \text { AMP-izopentenil transzferáz gén } \\ \text { MS } & \text { Murashige és Skoog (1962) alap táptalaj } \\ \text { MsFerr } & \text { lucerna (Medicago sativa) ferritin gén } \\ \text { NN } & \text { Nitsch és Nitsch (1969) által leírt táptalaj } \\ \text { NOA } & \text { naftoxi-ecetsav } \\ \text { nos } & \text { nopalin-szintáz gén } \\ n p t I I & \text { neomycin-foszfo-transzferáz gén } \\ \text { PTGS } & \text { poszttranszkripcionális génelhallgattatás } \\ \text { TDZ } & \text { thidiazuron \{1-phenyl-3-(1,2,3-thidiazol-5-yl)-urea }\}\end{array}$




\section{BEVEZETÉS}

A szőlő világszerte jelentős gazdasági növény, mind maga a gyümölcs, mind pedig a borfogyasztás szempontjából. Becslések szerint Európában 4 millió hektáron folyik szőlőtermesztés, a megtermelt mennyiség pedig 2009-ben elérte a 27 millió tonnát (FAO statistics, http://faostat.fao.org). A szőlő a mezőgazdaság erősen környezetszennyező kultúrái közé tartozik a felhasznált növényvédöszerek mennyisége miatt. A 19. század második felében az Amerikából Európába bekerült lisztharmat és peronoszpóra ma is a legnagyobb fenyegetést jelenti a világ szőlötermesztésére, amely megköveteli a fungicidek folyamatos használatát. Az anyagi ráfordítás, a környezeti terhelés és ezzel együtt egészségünk védelme érdekében is a rezisztens fajták termesztése jelenthet egy kedvezőbb megoldást a szőlő növényvédelmében. A gombabetegségeken kívül jelentős károkat okozó Agrobacterium vitis, illetve a szőlő vírusos betegségei ellen pedig nincs is hatékony növényvédelmi kezelés. A szőlőülttetvényekben levő tőkék a különböző gomba-, baktérium-, és vírusfertőzéseken kívül számos abiotikus környezeti stresszhatásnak vannak kitéve; ilyenek a magas fényintenzitás, ultraibolya B sugárzás, magas fémion koncentráció, magas vagy alacsony hömérséklet, vízhiány, víztöbblet és sebzés. A különböző stresszhatások jelentősen befolyásolják a növények növekedését, produktivitását; és különböző morfológiai, fizológiai, biokémiai és molekuláris változásokat eredményezhetnek.

A súlyosbodó környezeti problémák következtében egyre nagyobb teret nyertek a stresszélettani kutatások, melyek során fény derült arra is, hogy számos, meglehetősen különböző életfolyamatokat befolyásoló stressztényező hatása közös folyamatokra vezethető vissza. Ilyen általános stresszreakció az oxigénanyagcsere zavara következtében kialakuló különböző mértékben redukálódott aktív oxigénformák sejten belüli felhalmozódása, melyek károsító hatása olykor jelentősebb, mint az adott abiogén stressztényező egyéb hatásai.

A Budapesti Corvinus Egyetem Genetika és Növénynemesítés Tanszékén több mint harminc éve kezdődött meg a biotikus és abiotikus stresszel szemben ellenálló rezisztens szőlőfajták keresztezéses nemesítése. Az előállított fajták (pl. 'Kunleány’, 'Kunbarát') a magyar szőlőtermesztésben jelentős szerepet játszottak, míg az új bor-, és csemegeszőlő fajtákat és fajtajelölteket jelenleg értékeli a piac (pl. 'Orpheus', 'Taurus'). Napjainkban egyre nagyobb figyelem irányul a molekuláris nemesítési módszerekre, a vélemények 
pedig a növénynemesítés e lehetőségeiről megoszlanak. A társadalom megfelelö tájékoztatásával és a kutatómunka felelősségteljes végzésével az aggályok eloszlathatók. Erre azért is szükség van, mert a hagyományos keresztezéses nemesítési eljárásokhoz képest kevésbé időigényes technológiákkal állíthatók elő olyan új genotípusok, amelyek akár csak egyetlen tulajdonságban különböznek a kiindulási fajtától. A szőlő esetében különös figyelmet érdemel ez a nemesítési módszer, mivel a hagyományos nemesítési munka során egy új szőlőfajta piacra kerülése akár húsz évet is igénybe vehet. Figyelembe kell venni azt is, hogy egy új szőlőfajtának, akármilyen értékes tulajdonságokkal rendelkezzen is hagyományos társaihoz képest, kevés esélye lenne az elterjedésre a borfogyasztást meghatározó konzervativizmus, valamint a világfajták piacmeghatározó szerepe miatt. Ezért inkább az tüzhető ki célul, hogy az alapfajtától csak egyetlen tulajdonságban különböző fajtaváltozatokat hozzunk létre, amelyek jól alkalmazkodnak a különféle termesztési helyekhez, körülményekhez.

Az 1863-ban Amerikából behurcolt filoxérának köszönhetően vált szükségessé és terjedt el az oltás gyakorlata a szőlőtermesztésben. Az oltványelőállítás során felhasznált alanyok fokozottan ki vannak téve a különböző abiotikus stresszhatásoknak az árutermelő ültetvényekben, ezért az alanyfajták genetikai módosítása egy megfelelő alternatíva lehet az oxitatív stressz rezisztencianemesítésben. Az alanyhatásnak köszönhetően pedig a nemes fajták stressztürőképessége is fokozható.

A hasznos génekkel vézett transzformációs kísérletek a GM növények elöállításán túl sokat segíthetnek a szőlő genom megismerésében, ezáltal közvetett módon támogatják a nemesítést is. Napjainkban a genetikai transzformáció a növényi funkcionális genomikai kutatás egyik kulcsmódszerévé vált, ami izolált gének beépítését és így transzgénikus növények előállítását jelenti. A Budapesti Corvinus Egyetem Genetika és Növénynemesítés Tanszékén bizonyos szőlőfajták esetében rendelkezésre állnak a feltételek transzgénikus növények előállításához, lehetővé téve a genetikai kutatások legújabb eredményeinek hasznosítását a gyakorlatban szoros együttmüködésben más hazai kutatóintézetekkel. 


\section{CÉLKITÜZÉS}

A Budapesti Corvinus Egyetem Genetika és Növénynemesítés Tanszékén az elmúlt években számos fajtára dolgoztak ki növényregenerációs eljárást és a Tanszéken optimalizált transzformációs rendszert felhasználva modell génekkel transzformált növényeket állítottak elő. E munka folytatásaként, az eddigi eredményeket hasznosítva, hosszabb távon a gyakorlat számára is hasznosítható génekkel módosított növényeket kívántunk előállítani. A dolgozat alapjául szolgáló kísérletek során a fő célunk az volt, hogy Agrobacterium vektor felhasználásával hozzunk létre Agrobacterium rezisztens, illetve növelt oxidatív stressz ellenállóságot mutató szőlő növényeket. A kitüzött cél eléréséhez szükséges munkát több szakaszra osztottuk fel.

Első lépésben a genetikai transzformációhoz elengedhetetlen szőlő regenerációs rendszerek továbbfejlesztését kívántuk megvalósítani. Munkánkat mind az organogenezis mind a szomatikus embriogenezis területén terveztük elvégezni, szomatikus embriogenezis esetében a fajták és genotípusok széles körén, különös tekintettel a Tanszékünkön előállított fajtákra. Kutatásaimhoz nagy segítséget nyújtott, hogy a Budapesti Corvinus Egyetem Genetika és Növénynemesítés Tanszékének munkatársai rendelkezésemre bocsátották a ‘Richter 110' szőlő alanyfajta embriogén sejttenyészeteit, így tapasztalatokat szerezhettem a szőlő embriogén sejttenyészetek felszaporításáról és a szomatikus embriogenezisen keresztül történő növényregenerációról.

Második lépésben célunk volt a szőlő genetikai transzformáció körülményeinek optimalizálása azáltal, hogy a transzformációs kísérletekhez felhasznált embriogén anyagot homogenizáljuk és a folyamatos szelekciós nyomás mellett fenntartott feltételezhetően transzformáns szomatikus embriók regenerációs hatékonyságát növeljük, valamint a regenerációs idő hosszát lerövidítsük.

Harmadik lépésben a hatékony regenerációs és transzformációs technikákat a szőlőtermesztési gyakorlat számára is hasznos információkkal szolgáló génkonstrukciók felhasználásával a következő területeken kívántuk hasznosítani: a szőlő oxidatív stressztürő képességének növelése lucerna ferritint termelő növények előállításával, illetve Agrobacterium rezisztens növények elöállítása az A. tumefaciens virE1 génjének expresszáltatásával, valamint a géncsendesítés mechanizmusával.

A tanszékünkön alkalmazott akklimatizációs eljárás a transzformált szőlő növények esetében nem müködött megfelelő hatékonysággal, ezért a Budapesti Corvinus Egyetem 
Szőlészeti és Borászati Kutató Intézetével (Kecskemét) együttmüködve különböző kísérleteket végeztünk el annak érdekében, hogy a transzformált és mikroszaporított szőlő növények edzését és üvegházba történő kiültetését hatékonyabbá tegyük.

Utolsó lépésben pedig a 'Pegazus', 'Csépi muskotály', 'Borostyán', 'Odysseus', 'Orpheus', 'Taurus', 'Korai bíbor' és 'Pannon frankos' tanszéki nemesítésủ fajták különböző Agrobacterium törzsekkel szembeni ellenállóságát kívántuk tesztelni a Budapesti Corvinus Egyetem Szőlészeti és Borászati Kutató Intézetével (Kecskemét) együttmüködve. 


\section{IRODALMI ÁTTEKINTÉS}

\subsection{A regenerációs módszerek történeti áttekintése}

Az izolált növényi részek in vitro tenyésztése a sejtkultúrákkal kezdődött. A növényi sejtek, szövetek mesterséges, laboratóriumi körülmények között való tenyésztését először a német Haberland (1902, in Dudits and Heszky 1990) kezdte meg. A szerv- és az embriótenyésztésben először Hannig (1904, in Dudits and Heszky 1990) ért el sikereket. A második nagy áttörést Kotte (1922, in Dudits and Heszky 1990) hozta, akinek sikerült gyökércsúcsokat tenyésztenie táptalajon. A táptalaj hatására az inokulumok nem csak növekedtek, hanem oldalgyökereket is fejlesztettek (Maróti 1972, in Dudits and Heszky 1990). Az embriótenyésztésben a francia Mallyard (1921, in Dudits and Heszky 1990) és a német Laibach (1925, in Dudits and Heszky 1990) ért el eredményeket. Rájöttek, hogy a különböző kultúrák létesítésének az a feltétele, hogy a sejtek és a szövetek osztódásra képesek, tehát merisztématikusak legyenek. A gyökér és hajtáskezdemények tenyésztése mellett egyidejüleg a levelek, virágok és a virágzati részek tenyésztésével is próbálkoztak (Bonner et al. 1939, in Dudits and Heszky 1990). A virág és virágrészek, illetve a termés aszeptikus tenyésztésének módszereit Gregory (1940, in Dudits and Heszky 1990), Taylor (1950, in Dudits and Heszky 1990) és Vasil (1957, in Dudits and Heszky 1990) dolgozták ki. Ezekre a kutatásokra alapozták a pollenből kiinduló járulékos embriók tenyésztését napjainkban, ámbár ezeket a kísérleteket 1952-ben egy nemzetközi botanikai kongresszuson egyes kutatók ,,a képzelet vad szárnyalásának” tartották (Dudits and Heszky 1990).

A növénybiotechnológia legnagyobb lehetőségét napjainkban - ellentétben a humán kutatásokkal - a növényi szervezet regenerálása jelenti, mesterséges körülmények között tenyésztett szomatikus sejtekböl. A regeneráció során az a cél, hogy a differenciálatlan sejtekből növényt kapjunk. A regenerációnak két fő módját sikerült indukálni és fenntartani, az organogenezist és a szomatikus embriogenezist.

\subsubsection{Organogenezis}

A szervdifferenciáció indításához a növény minden olyan része felhasználható inokulumként, amely merisztéma, kambiális vagy parenchima szövetet tartalmaz. A kultúra indításához a leggyakrabban felhasznált növényrészek a következők: levél-, szár-, és gyökérrészek, valamint virág, embrió és sziklevél (Flich et al. 1983). A táptalajra 
helyezett steril növényi rész sejtjein először gyakran dedifferenciálódott sejtek tömege, a kallusz alakul ki (Bingh et al. 1989). A kalluszkultúrák sejtösszetételük szempontjából heterogének, de általában homogén sejtpopulációnak tekinthetők (Maróti 1972, in Dudits and Heszky 1990). A sejtek sokféleségének különböző okai lehetnek. Ilyenek, pl.: a kallusz eredete, a tenyésztés fizikai körülményei (fény, hö, levegő), a vizsgált szövetrész és a táptalaj összetétele. A kalluszszövetből kiindulva az alaptápközeghez (ásványi elemek, cukor, vitaminok, inozit) hozzáadott megfelelő hormonok hatására szervképződés indukálódik (Linsmaier and Skoog 1965). A kalluszban lévő sejtekből egy olyan osztódási folyamat indulhat, amelynek során apikális merisztéma centrum alakul ki. Ebből gyökérés hajtáskezdemény, majd növényi szervek keletkeznek. A megfelelő tápanyagellátottság biztosítja a citoplazma felépítéséhez szükséges anyagokat. A növekvő kalluszkultúrák sejtjeinek nagy része vakuolás, kisebb része pedig vakuola nélküli kambiális sejt. Ha ezekben a kultúrákban hosszabb inkubációs időtartamot vagy az osztódást gátló auxinkoncentrációt alkalmazunk, akkor a sejtek tágulnak és szállítószöveti elemek differenciálódnak. A gibberellinsav is fokozza a nyalábképződést kis auxinkoncentráció jelenlétében. A hajtástenyészetek leggyakoribb táptalaja az MS (Murashige and Skoog 1962) tápközeg tiamin és mezo-inozit kiegészítéssel. A fejlődő hajtások továbbszaporítása a nodális részekkel, illetve merisztémákkal folyhat (Dudits and Heszky 1990).

\subsubsection{Szomatikus embriogenezis}

Az embrió a fejlődése folyamán különböző morfológiai stádiumokkal jellemezhető: gömb, szív, torpedó és érett embrió (Ammirato 1983). Ezt az alakváltozást szövetdifferenciálódás kíséri. Az embriogenezist két fő szakaszra oszthatjuk, az első a heterotróf, a második az autotróf fázis. Az autotróf szakaszon belül megkülönböztetünk autonóm, élettani érettségi és ökológiai érettségi stádiumot. Az autonóm szakaszt az embrió növekedése jellemzi, az élettani érettség stádiumában az embrió eléri a teljes differenciáltságot. Az ökológiai érettség az embrió csíraképességét jelenti. Embriókultúrát nemcsak az embriók magból történő kipreparálásával és azok továbbnevelésével nyerhetünk. Megfigyelték, hogy a szomatikus sejtek 2,4-D-t (2,4-diklórfenoxi-ecetsav) tartalmazó táptalajon sejtaggregátumokat képeznek. Ha ezeket 2,4-D-t nem tartalmazó táptalajra helyezzük, az osztódások száma lecsökken és a sejtekből gömb alakú proembrioidok indulnak fejlődésnek. Az embriogén sejtekből álló kallusz egy grízszerü szerkezetet mutat, sárgásfehér színü (Forgács et al. 2011). Folyadékkultúrában a kallusz 
állapota mikroszkópos vizsgálattal jól elkülöníthető. Az embriogén kallusz sejtjei gömbszerűek, kis vakuólumokkal rendelkeznek és sok keményítő található bennük. A szomatikus embriogenezis a gömb stádiumig megegyezik a zigótás embriogenezissel, a gömb stádium elérése után a szomatikus embriókon kialakulnak a felületi epidermiszsejtek és a protoplasztiszok fejlődésével lassan megindul a fotoszintézis, így fény jelenlétében az embrioidok megzöldülnek (Ammirato 1983).

\subsection{A szőlőregenerációs kísérletek eredményei}

A sikeres genetikai transzformációs kísérletek alapja a hatékony növény-sejtnövény regenerációs rendszer. Az első sikeres járulékos organogenezisről szőlő esetében Rajasekaran és Mullins (1981), szomatikus embriogenezisről Mullins és Srinivasan (1976) közöltek először eredményeket. Napjaink irodalmát áttekintve elmondhatjuk, hogy a különböző transzformációs eljárásoknál gyakran alkalmaznak szomatikus embriókat. A szomatikus embriók indukciójára, valamint a transzgénikus növények regenerációjára többféle eljárás létezik. Különbség mutatkozhat a fajták között a felhasznált növényi részben, a táptalaj összetételében és a kísérleti körülményekben. A fajták közötti különbségeket Maillot és munkatársai (2006) embriogén kallusz indukciós kísérletei is alátámasztják. Kísérleteikben 6 Vitis vinifera és a $[(V$. berlandieri $\mathrm{x} V$. colombard $) \times(V$. vinifera $\mathrm{x} V$. berlandieri)] eredetü 'Fercal' alanyfajta egy-rügyes hajtás darabjain kaptak embriogén kalluszt. A 'Fercal' alanyfajta esetében az embriogén kallusz indukció levél szegmenseken is sikeres volt.

Nakano és munkatársai (1997) 23 genotípussal dolgoztak. A V. vinifera, $V$. x labruscana és $V$. rupestris fajokat felhasználva levélből, portokból és magházból indítottak kultúrákat. Harst (1995) levéllemezből és nyélből indult ki, a $V$. thunbergii és az inter-specifikus ‘Chancellor' hibrid felhasználásával. Később (Harst et al. 1998) V. vinifera fajtajelöltekböl valamint a 'Rajnai rizling', a 'Dornfelder' és a 'Rizlingszilváni' fajtákból indított portokkultúrákat, amelyekből szomatikus embriókat kapott. Scorza és munkatársai (1995) zigotikus embrióból indultak ki, a kísérletben három különböző genotípusú magvatlan $V$. vinifera fajtajelölt (2-19-6; 72-659-2; 69-636-5) szerepelt. Levéllemez felhasználásával (Scorza et al. 1996) a 'Thompson' V. vinifera fajta esetében kaptak szomatikus embriókat. Vilaplana és Mullins (1989) 'Sultana', 'Granache’ és 'Gloryvine' hipokotilból és járulékos gyökérből állítottak elő szomatikus embriókat. Portok kultúrából indult ki és embriogén kalluszt kapott Cersosimo és munkatársai (1990) $V$. rupestris és $V$. 
berlandieri fajokból; Mozsár és Süle (1994) V. vinifera fajtákból ('Chasselas', 'Szürkebarát', 'Ezerjó', 'Piros Szlanka', 'Ezeréves Magyarország Emlékére'), valamint a V. amurensis és a Vitis sp. 'Georgikon 28' esetében; továbbá Perl és munkatársai (1996) a 'Superior' $V$. vinifera fajtánál. Szintén portok kultúrából kiindulva, de szomatikus embriókat is kapott a $V$. rupestris faj esetében Martinelli és Mandolino (1994). Számos fajta esetében (többek között 'Chardonnay', 'Favorit', 'Kunleány’ stb.) számoltak be Oláh és munkatársai (2003b) embriogén sejttenyészetek előállításáról portokon.

Portokon embriogén kallusz fejlődés indukálására leggyakrabban a 2,4-D és BA (benzil-adenin) kombinációját használják (Martinelli and Gribaudo 2001a). Pino-Sintra (2007), ill. López-Pérez és munkatársai (2005) embriogén kallusz indukciós kísérleteikben szintén a 2,4-D és BA használatát találták a leghatékonyabbnak a fajták széles körében. Emellett Mullins és Srinivasan (1976), Stamp és Meredith (1988) kísérleteiben a NOA (naftoxi-ecetsav) és BA hormonkombináció is hatékonynak bizonyult. Murthy és munkatársai (1998) fedezték fel, hogy létezik egy szintetikus vegyület, a thidiazuron [TDZ, 1-phenyl-3-(1,2,3-thidiazol-5-yl)-urea], amellyel a szomatikus embrio- és morfogenezis hormonális igénye helyettesíthető. Ezt a vegyületet néhány Vitis genotípus esetében sikeresen használták arra is, hogy a BA-t helyettesítsék vele; bár az eredmény erősen függött attól, hogy milyen típusú szövettenyészetet és genotípust használtak a kísérletek során. 'Seyval blanc' levélkorongok és protoplasztok esetében szomatikus embriogenezis indukálására 0,88-0,90 mg/l TDZ-t használtak (Harst 1995, Reustle et al. 1995). Hasonló koncentrációkat $(0,88-1,1 \mathrm{mg} / \mathrm{l})$ alkalmaztak folyékony kultúrában másodlagos embriók fejlődésének indukálására (Bornhoff and Harst 2000), illetve, hogy embriogén vonalakat indítsanak portokokról (Iocco et al. 2001). Nakano és munkatársai (1997) 2,2 mg/l TDZ-t használtak, hogy másodlagos embriogenezist indukáljanak különböző genotípusú levél explantátumokon. Különböző szőlö genotípusok mikrospóra tenyészeteinél 0,2-2,0 mg/1 TDZ-t használtak embriógenezis indukálására (Sefc et al. 1997), 'Rajnai rizling' portokok esetében pedig két hetes BA kezelés után 2,2 mg/l TDZ-t alkalmaztak (HarstLangenbucher and Alleweldt 1993). Vitis x Labruscana esetében az embriogén vonalak hosszú távú fenntartásához 0,044 mg/l TDZ is elegendőnek bizonyult (Motoike et al. 2001). Több alanyfajta esetében is ('Börner', 'Richter 110', 'SO4', 'St. George', 'Teleki 5C') sikeresnek bizonyult a $0,05 \mathrm{mg} / \mathrm{l} \mathrm{TDZ}$ alkalmazása az elmúlt években (Oláh et al. 2003a). A különböző növényi növekedésszabályozók használata mellett a táptalajok elemi összetételét érintő minőségi és mennyiségi változások szintén hatással vannak az embriogén kallusz indukcióra (Perrin et al. 2001). 
Torregrosa (1998) V. rupestris x V. berlandieri eredetü 'Richter 110’ alanyfajtáról indított portokkultúrát, amelyet két különböző auxin-koncentrációjú táptalajra helyezett. Az első táptalaj $5 \mu \mathrm{M}$ 2,4-D-t és $5 \mu \mathrm{M}$ NOA-t, a második táptalaj 2,5 $\mu \mathrm{M}$ 2,4-D-t és 2,5 $\mu \mathrm{M}$ NOA növekedésszabályzó anyagot tartalmazott. Hat hét elteltével a kettes típusú táptalajon indult meg az elsődleges és másodlagos embriogenezis. A torpedó (2-4 mm hosszú) alakban lévő embriók fél MS alaptáptalajra kerültek át. Az embriókat transzformációhoz használta fel.

Vidal és munkatársai (2009) nyolc különböző $V$. vinifera fajta embriogén kapacitását vizsgálták portok és ovárium tenyészetekben. Kísérleteikben a különböző fejlettségi stádiumban indított kultúrákat 2,4-D és BA hormonkombinációval kiegészített MS, illetve 2,4-D és NOA tartalmú NN táptalajra helyezték. Kikkert és munkatársai (2005) embriogén kallusz indukciós kísérleteikben 12 fajta (Vitis $s p$.) ovárium és portok tenyészeteit tesztelték három különböző táptalajon. Gambino és munkatársai (2007) öt $V$. vinifera és a $V$. berlandieri x $V$. rupestris cv. 'Richter 110' alanyfajta embriogén kallusz indukciójához éretlen virágbimbókat, ováriumokat és portokokat helyeztek 2,4-D-vel és BA-nel kiegészített NN táptalajra. Kísérleteikben a virágbimbók alkalmazása a legtöbb fajta esetében hatékonyan müködött, a 'Richter 110', 'Chardonnay' és 'Grignolino’ fajták esetében pedig a portokkultúrákban kapott eredményeket is meghaladta.

Cutanda és munkatársai (2008) a 'Macabeo' és 'Tempranillo' $V$. vinifera fajták embriogén kapacitását vizsgálták két különböző fejlettségi állapotban lévő portokokon. A portokokat portoknyéllel együtt helyezték a táptalajra. A kiindulási anyag fejlettsége mellett tesztelték a 48 órás $4^{\circ} \mathrm{C}$-on történő hidegkezelés hatását, valamint két különböző táptalaj hatását az embriogén kallusz indukcióra. Kísérleteikben megfigyelték, hogy legnagyobb gyakorisággal a portoknyélen kaptak embriogén kalluszt.

Perrin és munkatársai (2004) embriogén kalluszindukciós kísérleteikben 13 nemes-, és 6 alanyfajta portoknyéllel együtt kipreparált portokait helyezték 2,4-D és BA hormonokkal kiegészített 5 különböző táptalajra. Megfigyeléseik szerint a portok kultúráknál nagyon gyakori a portoknyélen történő embriogén kalluszfejlődés, melyet véleményük szerint a portokok csészéről történő leválasztási módja is befolyásol. Ezért a 'Rajnai rizling' portoktenyészetekben kétféle eljárást hasonlítottak össze: a portokokat spontán leválasztották a csészéről, vagy a csatlakozási helytől körülbelül 0,5mm-nyi távolságra vágással távolították el azokat. Kísérleteikben a vágásos technológia szignifikánsan befolyásolta a portoknyélen fejlődőtt kallusz gyakoriságát, 18,04\%-ról 43,16\%-ra emelte azt. 
López-Pérez és munkatársai (2005) a 'Sugarone', 'Crimson Seedless', 'Italia' és a 'Don Marco' csemegeszőlőfajták portok-, és ováriumtenyészetein kaptak embriogén kalluszt a 2,4-D és BA hormonokkal kiegészített MS táptalajon. A szomatikus embriófejlődés indukálásához az embriogén kultúrák fél MS táptalajra kerültek át. Kísérleteikben tesztelték az aktív szén $(0,25 \%)$ hatását a szomatikus embriófejlődésre. A 'Crimson Seedless', 'Italia' és 'Don Marco' fajták esetében az aktív szén használata elengedhetetlennek bizonyult a szomatikus embriófejlődés indukálásához, a 'Sugarone' fajta esetében pedig a hatékonyságot sikerült növelni (5,8\%-ról 99,5\%-ra). Hébert-Soulé és munkatársai (1995) az aktív szén torpedó stádiumban lévő szomatikus embriókra gyakorolt jótékony hatását annak abszorpciós képességével magyarázza azáltal, hogy megköti a táptalajban jelenlévő potenciális csírázásgátló anyagokat.

Jayasankar és munkatársai (2003) a folyékony táptalaj alkalmazásának szomatikus embriogenezisre gyakorolt hatását vizsgálták. A 2,4-D és BA tartalmú szilárd MS táptalajra helyezett 'Chardonnay' és 'Thomson Seedless' portokokon, ill. levélkorongokon kapott embriogén kallusztenyészetekből 2,4-D-t tartalmazó szuszpenziós kultúrákat indítottak, majd a szilárd és folyékony tenyészetek további fejlődését a Li és munkatársai (2001) által leírt szilárd X6 táptalajon hasonlították össze. Kísérleteikben megfigyelték, hogy a folyékony táptalajból származó érett szomatikus embriók a szilád táptalajról származó embriókhoz viszonyítva kisebb sziklevelekkel és nagyobb méretü szuszpenzorral rendelkeztek. A hipokotil és a sziklevelek hosszának arányait vizsgálva megállapították, hogy a szilárd táptalajról származó szomatikus embriókon a sziklevelek hosszabbak voltak a hipokotilnál, a folyékony táptalajból származó embriókon pedig ez az arány pont fordítva alakult. A zigotikus embriókon a hipokotil és a sziklevelek hossza körülbelül azonos (Jayasankar et al. 2003). Korábbi megfigyeléseik szerint (Jayasankar et al. 1999) a zigotikus embriók fejlődésével ellentétben a folyékony táptalajból származó kultúráknál nem alakult ki magnyugalom. Gray and Purohit (1991a, b) szilárd táptalajról származó tenyészeteiken a szomatikus embriófejlődés indukálása során szintén megfigyelték a magnyugalmat, melyet aztán különböző kezelések hatására sikerült feloldaniuk. A magnyugalom a szomatikus embriók fejlődése során felhalmozódó abszcizinsavnak köszönhető (Rajaeskaran et al. 1982), és többek között exogén giberrelinsav alkalmazásával feloldható. Mivel a szuszpenzorban is történik giberrelin szintézis, ezért Jayasankar és munkatársai (2003) arra a következtetésre jutottak, hogy a szuszpenziós kultúrákból származó szomatikus embriók nagyobb méretű szuszpenzorának köszönhető a magnyugalom elmaradása ill. az embriók korábbi csírázása. 
Valerii és munkatársai (2003) az indolecetsav (IAA, 0,1 mg/l) és a BA (0,5 mg/l) hatását vizsgálták a 'Bianca', 'Podarok Magaracha' és 'Intervitis Magaracha' levélnyél darabokon fejlődött embriogén kallusz szuszpenziós tenyészeteiben. Megfigyeléseik szerint a gömb stádiumú embriók fejlődésére az IAA-val kiegészített NN táptalaj volt kedvező hatással, a BA tartalmú táptalaj használata a szív stádium elérését segítette. A torpedó stádium eléréséhez pedig szintén az IAA-val kiegészített NN táptalaj használata bizonyult kedvezőnek. A szomatikus embriók további fejlődéséhez 0,5 $\mathrm{mg} / \mathrm{l}$ gibberellinsavval (GA) kiegészített folyékony táptalajt használtak, majd a sziklevéllel rendelkező kis növényeket $0,5 \mathrm{mg} / \mathrm{l}$ BA-nel kiegészített szilárd táptalajon nevelték tovább.

Amar és munkatársai (2007) cukkini és petrzselyem, majd a 'Tempranillo' szőlőfajta szuszpenziós sejtkultúrákról származó, az ún. kondicionált táptalaj hatását vizsgálták különböző szőlőfajták portok eredetű embriogén kallusztenyészeteire. Kísérleteikben a NN táptalaj különböző változatait használták. Az indításkor $50 \mathrm{ml}$ kondicionált és $50 \mathrm{ml}$ friss táptalajt tartalmazó kallusztenyészetekben a megfelelő embriogén struktúrák gyors felszaporodását tapasztalták a kondicionált táptalaj eredetétől függetlenül. Az autoklávozás után felhasznált kondicionált táptalaj esetében azonban a $100 \%$ friss táptalajban indított szuszpenziós tenyészetekhez hasonló eredményeket kaptak. Amar és munkatársai (2007) azt is bizonyitották, hogy az induló tenyészetekre gyakorolt pozitív hatásért a kondicionált táptalajokban megtalálható arabinogalaktán extra-celluláris fehérje a felelős. Az embriogén kallusz felszaporítása után a tenyészeteket naponta friss hormonmentes folyékony táptalajba helyezték át. 5-6 hét elteltével a szinkronizált fejlődésű, torpedó stáiumban lévő szomatikus embriók aktív szénnel kiegészített táptalajra kerültek át, melyek aztán fényen gyökérrel és hajtással rendelkező növényekké regenerálódtak.

\subsection{A növénytranszformációs módszerek}

A genetikai transzformáció során a gazdanövény genomjába egy tetszöleges származású gént építhetünk be. Ezzel elérhetjük, hogy az idegen gént tartalmazó, úgynevezett transzgénikus növény valamilyen tulajdonságában felülmúlja az eredeti gazdanövényt. Az idegen gének bejuttatása történhet közvetlen módon, vagy vektorok közvetítésével (indirekt). Az alábbiakban a gyakorlati szempontból legfontosabb módszereket sorolom fel. 


\section{Közvetlen DNS-beviteli módszerek:}

\section{Transzformáció polietilén-glikol (PEG) felhasználásával}

Ezzel a módszerrel protoplasztokat transzformálhatunk. A gyengén negatív polaritású PEG-molekulák hidrogénhíd-kötéssel kapcsolódnak a víz, a fehérjék és a szénhidrátok megfelelő molekula részleteihez, valamint a $\mathrm{Ca}^{++}-$hoz is, melyet a PEG-gel együtt a protoplasztokhoz adagolunk. Ennek következtében a plazmalemmák molekulái között átrendeződés megy végbe, ami megbontja a sejthártya integritását, és így lehetővé válik a sejt számára az idegen eredetű DNS felvétele (Davey et al. 1980, Krens et al. 1982).

\section{Transzformáció elektroporációval}

Protoplasztok transzformálását teszi lehetővé az elektroporáció. A módszer lényege, hogy rövid ideig tartó erős elektromos impulzusok hatására a protoplaszt membránján átmenetileg lyukak képződnek, amelyeken keresztül az idegen DNS bejuthat a sejtbe. Emlőssejteken dolgozva igazolták először a DNS-felvétel megnövekedését elektromos impulzus hatására (Neumann et al. 1982). Később hasonló közlemények jelentek meg a növényi sejtekkel kapcsolatban is (Fromm et al. 1986, Riggs and Bates 1986).

\section{Mikroinjektálás}

A mechanikai úton történő DNS-bevitel egyik lehetséges módja a DNS-oldat beinjektálása a protoplasztokba, illetve közvetlenül a sejtmagba (Crossway at al. 1986). Az injektálás invert-mikroszkópra szerelt mikroinjektáló berendezéssel történik. A több ezer donor DNS kópiából mikroinjektáláskor 1-2 az intergálódott kópiák száma. Az állati sejtekbe (hímivarsejtek, petesejtek, zigóták, embrionális sejtek) történő géntranszfert ugyanezzel a módszerrel végzik.

\section{Génbelövés}

A „génbelövés” kifejezés a módszer lényegére utal, miszerint a DNS élő sejtekbe, szövetekbe történő juttatása egy génbelövő készülékkel (,génpuskával”) történik. Az eljárás lényege, hogy a DNS molekulákat hordozó mikrolövedékeket (1-2 $\mu \mathrm{m}$ átméröjü wolfram vagy arany részecskéket) He- illetve $\mathrm{N}_{2}$-gázzal nagy sebességre gyorsítják fel, így a részecskék áthatolnak a sejtfalon és a sejtmembránon, magukkal szállítva a sejtek belsejébe az idegen DNS-molekulákat. A sejtek egy része túléli az így okozott sérülést, 
osztódik és ezekből a sejtekből megfelelő szelekciós körülmények között növények regenerálhatók (Dudits and Heszky 1990).

\section{Transzformáció szilikonkarbid-tük felhasználásával}

A módszer lényege, hogy a tenyésztett növényi sejteket folyékony táptalajban, szilikon-karbid mikrotük és plazmid-DNS jelenlétében rázatják. Az eljárás során a mikroméretű szilikonkarbid tűk belefúródnak a sejtekbe, és magukkal viszik az oldatban lévő DNS molekulákat (Jenes 1999).

\section{Vektor alapú (indirekt) DNS-beviteli módszerek:}

\section{Vírusvektorok}

Elsősorban a kétszálú (Caulimosaic vírusok) és egyszálú (Geminivírusok) DNSvírusok kerültek alkalmazásra. A karfiol mozaik vírus (CaMV) klónozása során megfigyelték, hogy a klónozott vírus megtartotta fertőzőképességét. Azt is megfigyelték, hogy bizonyos DNS-szakaszok eltávolítása nem hat ki a vírus fertőzőképességére, és így az eltávolított DNS szakaszok helyére idegen rezisztenciagént építettek be (Brisson et al. 1984). Annak ellenére, hogy a transzformáció sikeres volt, több tényező is gátolja a módszer elterjedését. A vírusmolekula csak kisméretü DNS-szakasz befogadására képes, a vírusgének megnyilvánulása miatt pedig a transzformáns növényeken betegségtünetek jelennek meg. Lényeges hátrány továbbá, hogy általában szük a fertőzhető növények köre. A virális szekvenciák Agrobacterium T-DNS vektorba (lásd 3.4. fejezet) történő klónozása vezetett az ún. agroinfekciós rendszer kidolgozásához (Grimsley et al. 1987).

A vírusindukált géncsendesítést (VIGS) a növényi sejtben replikálódó vírusok indukálják saját RNS genomjukkal szemben. Ha a vírus genomja idegen szekvencia elemet is tartalmaz (amely homológ egy növényi endogén génnel), akkor az endogén gén mRNS-e is szekvenciaspecifikusan lebomlik és így az endogén gén hiányára jellemző fenotípus alakul ki a növényen. A VIGS ezen tulajdonsága lehetővé teszi, hogy a növények e védekező mechanizmusát felhasználva ismeretlen funkciójú szekvenciákhoz funkciót rendeljünk, vagy adott funkciójú gének funkcióvesztésének hatását vizsgáljuk (Burgyán 2006). 


\section{Agrobacterium vektorok}

Az Agrobacterium fajok szintén rendelkeznek azzal a képességgel, hogy a növényi genomba géneket juttassanak. Az Agrobacterium fajok és a velük való transzformáció lehetőségeit részletesen a következő fejezet tartalmazza.

\subsection{Az Agrobacterium mint transzformációs vektor}

Az Agrobacterium fajok egyedülállóan rendelkeznek azzal a képességgel, hogy a növényi genomba géneket integráljanak. A Rhizobiaceae családba tartozó, Gram-negatív, patogén talajbaktériumok az Agrobacterium nemzetség képviselői, az A. tumefaciens, az A. vitis, az A. rhizogenes és az A. rubi fajok. A kétszikü növényeket sebzési helyeken fertőzik, majd a fertőzött növényeken tumorfejlődést, illetve hajszálgyökeresedést okoznak. Az $A$. rhizogenes föleg almatermésü gyümölcsfajokat, míg az A. rubi a Rubus fajokat betegíti. Az A. tumefaciens számos növényfajon indukál tumorképződést, az A. vitis pedig a szőlőn idéz elő törzs-, kar-, vagy vesszőgolyvát (Folk and Glits 1993).

A szőlő agrobaktériumos vesszőgolyvája a földünkön mindenhol előforduló betegség, amely az intenzív müvelésü ültetvényekben súlyos terméskiesést is okozhat. A fertőzött növények gyengén fejlödnek, levélzetük sárgászöld vagy vöröses, a levelek olykor kanalasodók. A talaj feletti részeken karfiolszerü, egyenetlen felületü tumorok képződnek (Folk and Glits 1993).

A tumorszövetek in vitro hormonmentes táptalajon növekedésre képesek és specifikus aminosav származékokat ún. opinokat (pl. oktopint, nopalint, agropint) termelnek, szemben az egészséges növényi szövetekkel. A tumorképződésért és az opinszintézisért az Agrobacterium sejtekben található Ti-plazmid felelős (Zaenen et al. 1974). DNS hibridizációval igazolták, hogy a baktériumfertőzés során a Ti-plazmid egy része, az ún. transzfer vagy T-DNS átkerül a növényi sejtekbe, és stabilan integrálódik a sejtmag DNS állományába. Ezek a kísérleti eredmények nagyon fontosak voltak, mert fényt derítettek egy természetes génátviteli mechanizmusra, amelynek során bakteriális gének épülnek be a fertőzött növények sejtmagi örökítőanyagába.

A T-DNS hozzávetőlegesen 21-23 kilobázis hosszúságú, amelyen a tumoros növekedésért és az opinszintézisért felelős gének lokalizálhatók, és amelyet két rövid, 25 bázispár hosszúságú ismétlődő határszekvencia (bal oldali határoló régió: LB, jobb oldali határoló régió: $\mathrm{RB}$ ) vesz körül. A tumoros növekedésért felelős gének növényi növekedési hormonok bioszintéziséért felelős fehérjéket kódolnak, melyek túltermelése felborítja a 
normál növényi sejtosztódást és differenciációt. Az egyik növekedési hormon az auxin (indol-3-ecetsav, IAA), melynek bioszintéziséért két gén, az iaaM és az iaaH által kódolt enzim, a triptofán-monooxigenáz és az indol-3-acetamid hidroláz a felelős. A másik hormon a citokinin (zeatin), amelynek képződésében az ipt gén által kódolt AMPizopentenil transzferáz enzim vesz részt. Az enzim által létrehozott vegyületet (izopentenilAMP) a növény által kódolt enzimek gyorsan tovább alakítják zeatinná.

A Ti-plazmidon végzett deléciós analízis igazolta, hogy a két T-DNS határolószakasz (LB, RB) között található gének nem befolyásolják a T-DNS átvitelt és integrációt (Miranda et al. 1992). Az átvitel folyamatában a Ti-plazmidon lévő virulencia (virA virG) régiónak, valamint a kromoszómális virulencia $(\operatorname{chvA,} \operatorname{chvB)}$ régiónak van meghatározó szerepe. A chv gének folyamatosan, úgynevezett konstitutív módon nyilvánulnak meg és termékeik a baktérium sejtfalhoz tapadását okozzák, a vir gének expressziója viszont szigorúan szabályozott, és aktiválódásuk indítja el az átviteli mechanizmust. A sérült növényi szövetekből kiszabaduló fenol vegyületek, mint például az acetosziringon, indukálják ezen gének átírását.

A vir gének 8 operonba rendeződve, a mintegy 40 kbp kiterjedésü vir-régiót alkotják a plazmidon. A virA régió által kódolt protein egy un. szenzor fehérje, mely a növényi sebzés során keletkező fenolszármazékokat közvetlenül érzékeli (Lee et al. 1996), majd aktiválja a vir $\mathrm{G}$ gént. A monoszacharidok a kromoszómálisan meghatározott ChvE proteinhez kapcsolódnak először, mely kölcsönhatásba lép a virA proteinnel. A virG ezt követően elindítja a teljes virulencia rendszer müködését (kétkomponensü szabályozó rendszer). A virD1 protein a T-DNS jobboldali határszakaszán bemetszi a Ti-plazmidot és ezt követően a keletkező egyszálú T-szál 5'-végéhez kovalens kötéssel kapcsolódik a virD2 protein. A bevágásnál keletkezett 3'-végtől a DNS-szintézis során a szál újra felépül, miközben a virD2-vel kapcsolódó 5'-vég letolódik a komplementer szálról (a régió másik határszekvenciájáig). Az így leváló egyszálú DNS-t a virE2 proteinek stabilizálják. A virD2 protein részt vesz a T-DNS növényi kromoszómális DNS-be történő integrálódásnak meghatározásában is. A bakteriális, illetve a növényi sejtmembránon való átjutást a membránba épült virB fehérjék biztosítják. A folyamat nagyfokú hasonlóságot mutat a baktériális konjugációval, pl. a T-DNS jobbboldali határszakasz és a konjugatív plazmidoknál az oriT meghatározó szerepe, az egyszálú T-szál 5'-végü polarizáltsága, valamint a sejtmembránokon keresztül történő protein exporttal (Christie 1997, Hooykaas and Beijersbergen 1994, Kado 1994, Lessl and Lanka 1994, Sheng and Citovsky 1996, 
Tinland et al. 1995, Waters and Guiney 1993, Weising and Kahl 1996, Zupan and Zambryski 1995).

Mivel a T-DNS jobb-, és baloldali határszakaszai közötti szekvenciák a T-DNS integráció szempontjából nem meghatározóak, ezért az Agrobacterium Ti-plazmid T-DNS része alkalmas arra, hogy vektorként felhasználva idegen géneket építsünk bele és juttassunk be általa magasabbrendü növényekbe (Gheysen et al. 1987). A növényi genomba épült mesterséges T-DNS a továbbiakban növényi szekvenciaként funkcionál. Ezek az alapvető felismerések vezettek el a különböző növényi transzformációs vektorrendszerek kidolgozásához.

Bár a vir gének aktiválódása nagyrészt ismert az agrobaktériumos fertőzés során, semmit nem tudunk arról, hogyan inaktiválódik a vir regulon a növényi sejtek transzformációja után, ugyanis a T-DNS növényi genomba való integrálódását követően a vir gének expressziójára a továbbiakban nincs szükség. Mivel T-DNS szakasz kivágódásához és transzformációjához szükséges gének aktiválásában a növényi szignálmolekulák játszanak szerepet, nem lenne meglepő, ha baktérium fel tudná ismerni a transzformált sejteket egy jelzőmolekula segítségével (Liu and Nester 2006). Mivel a vir regulon csak akkor aktiválódik, amikor a baktérium a növény a közvetlen közelében van, valószínüleg létezik egy mechanizmus, amely a T-DNS integrálódását követően ugyanezt a regulont inaktiválja.

Liu és Nester (2006) kutatómunkájuk során rávilágítottak arra, hogy az indolecetsav - amelyet a T-DNS-en kódolt két enzim a tryptofán átalakításával termel - gátolja az A. tumefaciens C58 vir gén expresszióját azáltal, hogy versengés folyik a növény által termelt acetosziringon és az indol-ecetsav között a virA génnel történő kölcsönhatásért. Azt tapasztalták, hogy az indol-ecetsav gátolja a virA régió acetosziringon érzékelését, ugyanakkor az acetosziringon koncentrációjának növelésével csökkent az indol-ecetsav gátló hatása. Magasabb koncentrációban az indol-ecetsav az Agrobacterium és más növénypatogén baktériumok növekedését is gátolta, az indol-ecetsav megvonása után azonban a telepek folytatták növekedésüket.

Növények hiányában a növényi sejt transzformációjához szükséges gének nem expresszálódnak. Azonban a növényi rizoszférában lévő baktériumok felismernek néhány olyan növényi szignál molekulát, amelyek egy két-komponensủ szabályozó rendszeren virA/G - keresztül aktiválják a 30 vir génből álló regulont. Mivel a Ti-plazmidon lévő vir gének a növényi transzformációhoz szükségesek, ezért a baktérium számára felesleges, hogy folyamatosan szintetizálja azt a 30 fehérjét, amelyekneknek a fertőzés bekövetkezte 
után a továbbiakban nincs hasznos funkciójuk. A felismerést segítő növényi szignálmolekulák hiányában a virA defoszforizálhatja virG-t, ezáltal megakadályozva a vir gének indukcióját (Brencic et al. 2005). Liu és Nester (2006) megfigyelései szerint az Agrobacterium lecsökkentette a vir gének expresszióját érzékelve a transzformált sejtek által túltermeltetett indol-ecetsavat, ezért arra a következtetésre jutottak, hogy az indolecetsav a növényi transzformációs folyamatban egy jelző molekulaként vesz részt. Következésképpen az indol-ecetsav egy olyan molekula, amely szerepet játszhat a növények növénypatogén baktériumokkal szembeni védekezésében.

A DNS átvitele akkor is sikeres, ha a virulencia gének és a T-DNS két különböző plazmidon helyezkedik el az Agrobacterium sejten belül (Hoekema et al. 1983). Tehát a virulencia gének „transz” helyzetben is képesek a T-DNS mobilizációjához szükséges funkciók ellátására. A két funkció szétválasztása nyomán kifejlesztett növényi vektorrendszerek a kettős, ún. bináris vektorrendszerek. A T-DNS átvitelét segítő plazmid (,,vir helper plazmid”) általában olyan Ti-plazmid származék, amelyből a határszekvenciákkal együtt eltávolítják a teljes T-régiót. Számos helper plazmidot fejlesztettek ki napjainkra (Hoekema et al. 1983, Hood et al. 1993, Koncz és Schell 1986). Lefegyverzett vagy "disarmed" vektoroknak is nevezik azokat a nem patogén Tiplazmidokat, amelyekből részben vagy egészben hiányzik a T-DNS régió. A másik, a „klónozó” plazmid (,bináris vektor”), egy széles gazdaspecifitású vektor, mind E.coli, mind A. tumefaciens háttérben képes replikálódni, konjugációval könnyen átvihető az egyik baktériumból a másikba. Az ilyen klónozó vektorok tartalmazzák a T-DNS határszekvenciáit, ezen belül a növényi szelekciós markergéneket, mint pl. kanamicin-, higromicin-, vagy herbicid rezisztencia (Gasser and Fraley 1989, Weising et al. 1988), a klónozásra alkalmas helyet, ezen kívül a plazmid replikációjáért és stabilitásáért felelős géneket, valamint a bakteriális szelekciós markert (pl. kanamicin, gentamicin rezisztencia). Ezek az integratív vektorrendszerek már transzformáns növények létrehozását is lehetővé tették, mivel a transzformált növényi sejtekből, a megfelelö hormonok alkalmazásával, regeneráltatható a teljes, transzgént hordozó növény.

Az első bevezető kísérletek óta (DeBlock et al. 1984) számos, a gyakorlat szempontjából is fontos tulajdonságot sikerült növényekbe bevinni (pl. herbicid rezisztencia, Gasser and Fraley 1989). Amennyiben a géneket transzformáció során, pl. a kloroplasztiszba építjük be, sokkal intenzívebb génmegnyilvánulást kapunk, mint a kromoszómába beépített T-DNS esetében. Mivel az öröklésmenet ebben az esetben 
citoplazmához kötött, nem áll fenn a veszély, hogy az újonnan bevitt gén pollennel kikerülhet a természetbe (McBride et al. 1995).

\subsection{A szőlő genetikai transzformációjának eredményei}

A szőlő transzformációs kísérletek során szintén sikeresen alkalmazzák növényi génvektorként az Agrobacterium törzseket. Mára számos szőlőfajtán végezetek el sikeres transzformációt Agrobacterium alapú génvektorok segítségével. A szőlö transzformációnál gondot jelent, hogy csak néhány genotípusra van kidolgozva olyan eljárás, amellyel rutinszerüen lehet növényt regenerálni.

Néhány alanyfajta megfelelő rezisztenciát mutat a különböző gombás betegségekkel szemben, de a legtöbbjük érzékeny az abiotikus stresszre valamint a gombaés vírus-fertőzésekre. Legyőzendő ezeket a nehézségeket, a molekuláris nemesítési eljárásokkal próbálják javítani a szőlőfajták stressz és betegség ellenállóságát (Perl and Eshdat 1998, Vivier and Pretorius 2000, Colova-Tsolova et al. 2001, Kikkert et al. 2001, Martinelli and Mandolino 2001b). Bár az utóbbi időben előállítottak transzgénikus alanyfajtákat is (Mullins et al. 1990, Le Gall et al. 1994, Krastanova et al. 1995, Mozsár et al. 1998, Xue et al. 1999), a regenerációs eljárás csak néhány fontosabb genotípusnál ismert. A gus ( $\beta$-glükoronidáz) génnel végeztek kísérleteket alanyokon Berres és munkatársai (1992) a V. riparia x V. berlandieri '41B', a V. berlandieri x V. riparia 'SO4', és '5BB' transzformációjával és GUS pozitív kalluszt kaptak. Mauro és munkatársai (1995) is a $V$. riparia x $V$. berlandieri '41B' és a $V$. berlandieri x $V$. riparia 'SO4' alanyokat használták nptII/GUS/GFLV-CP génekkel történő transzformációs kísérleteik során. Később (1998) a $V$. riparia x $V$. berlandieri '41B' alany esetében $G F L V$ gén bevitelével kaptak transzformáns növényeket. A $V$. berlandieri $\mathrm{x} V$. rupestris $\mathrm{cv}$. 'Richter 110' alanyfajtán LeGall és munkatársai (1994) végeztek transzformációs kísérleteket, amelynek során embriogén kalluszból kiindulva a hyg/nptII/GUS/GCMV-CP gének bevitelével hygromicin és kanamicin rezisztens, GUS pozitív és GCMV-CP előállító növényeket kaptak. Gölles és munkatársai (1998) a 'Richter 110' alanyfajtáról származó embriogén kalluszt GFLV, ArMV, GVA és GVB köpenyfehérje génekkel transzformálták és transzformáns növényeket kaptak. Coutos-Thévenot és munkatársai (2001) a V. riparia x $V$. berlandieri '41B' alanyfajta embriogén szuszpenzióját használták fel transzformációs kísérleteikhez. A felhasznált génkonstrukcióval - amely egy a lucernából származó patogén indukált promóter mögött tartalmazta a VST1 (sztilbén-szintáz) gént - Botrytis cinerea és 
Eutypa lata fertőzésekkel szemben fokozott ellenállóságot mutató növényeket állítottak elö. Magyarországon Mozsár és munkatársai (1998) a 'Georgikon 28' alanyfajta esetében értek el eredményeket, Oláh és munkatársai (2003a) a 'Richter 110' és 'St. George' fajtákat sikeresen transzformálták nptII/GUS génekkel.

V. vinifera fajták esetében többek között Guellec és munkatársai (1990) 'Greanche' gyökerek transzformációjára a C58C1 (pGV3850::1103neo, pRi15834) vektort használták, amelynek eredményeként nptII és opin pozitív kallusz kaptak. Harst és munkatársai (1998) a 'Dornfelder', a 'Rizlingszilváni' és a 'Rajnai rizling' portokból és levélből előállított szomatikus embriókat transzformálta nptII génnel, amelynek eredményeképpen a 'Dornfelder' és 'Rajnai rizling' fajtákból kapott transzformánsokat. Kikkert és munkatársai (1998) 'Merlot' és 'Chardonnay' embriogén sejtszuszpenziót használtak fel a kitináz enzimet kódoló génnel történő transzformációra és kitináz pozitív növényeket kaptak. Bornhoff és munkatársai (2005) 'Seyval blanc' levélkorongok transzformációjával állítottak elő kitináz és RIP (riboszóma inaktiváló protein) expresszáló növényeket. A transzgénikus vonalak Uncinula necator és Plasmopara viticola fertőzése során azonban nem tapasztaltak statisztikailag igazolható toleranciát. Az nptII/GUS gén bevitelével értek el eredményeket Mullins és munkatársai (1990) a 'St. George' V. rupestris hipokotil, a 'Cabernet sauvignon' és 'Chardonnay' V. vinifera fajták levélnyél transzformációjával. A kísérlet során a 'Cabernet sauvignon' és 'Chardonnay’ fajtáknál GUS pozitív rügyeket, a 'St. George-nál' pedig nptII és GUS pozitív növényeket kaptak. Legrand és munkatársai (2003) transzformációs kísérleteikben a Vigna radiata eredetű eutypin detoxifikáló enzimet (Vr-ERE) kódoló gént használták fel. A regenerált szőlő növények toleránsak voltak az Eutypa lata fertőzéssel szemben. Oláh és munkatársai (2003b) portok eredetü embriogén kalluszt transzformálva sikeresen állítottak elő nptII/GUS génekkel transzformált vonalakat. Li és munkatársai (2001) az in vitro 'Thompson Seedless' növények levélkorongjain kapott embriogén kallusztenyészetek transzformációja során különböző promóterek hatását vizsgálták a green fluorescent protein (GFP) és az nptII szelekciós markergén expressziójára. Vidal és munkatársai (2006) az antimikrobiális magainin génnel (mag2) és szintetikus változatával (MS199) transzformáltak 'Chardonnay’ szuszpenziós embriogén kultúrákat. A regenerált transzgénikus vonalakat lisztharmattal és az A. tumefaciens C58, A. vitis Tm4, CG450 törzsekkel fertőzték. A nem-transzformált kontroll növényekhez viszonyítva csökkent tumorfejlödést tapasztaltak minkét gén esetében. A liszharmatfertőzés során azonban csak két mag2 vonal mutatott enyhe toleranciát. Agüaro és munkatársai (2006) a körte poligalakturonáz enzim génjének ( $p G I P$ ) 
felhasználásával a Xytella fastidiosa által okozott Pierce baktériumos betegséggel szemben növelt ellenállóságot mutató 'Chardonnay’ és 'Thomson Seedless' transzgénikus vonalakat állítottak elő.

\subsection{A növényi stressztürőképesség fokozásának lehetőségei}

Az abiotikus és biotikus stressz, mint a legföbb limitáló tényező játszik szerepet a növények életében. A különböző stresszhatások jelentősen befolyásolják a növények növekedését, produktivitását; és különböző morfológiai, fizológiai, biokémiai és molekuláris változásokat eredményezhetnek. Amikor a növények stresszhatásnak vannak kitéve, számos gén expressziója megnövekszik, ami pedig különböző fehérjék és metabolitok felhalmozódását eredményezi. Ezen felhalmozódó anyagok valószínűsíthetően a növényi sejtek védelméért felelösek a különböző stessz körülmények között. Ahhoz, hogy a különböző stresszhatások következtében jelentkező károsodások ellen hatékonyabban tudjunk védekezni, először az ilyenkor végbemenő sejt szintü, biokémiai és molekuláris folyamatokat kellett megismerni. A stressz-indukált génexpresszió három fö csoportra osztható: (1) ismert enzimatikus vagy strukturális funkcióval rendelkező fehérjéket kódoló gének, (2) számunkra még egyenlöre ismeretlen funkcióval rendelkező fehérjéket kódoló gének és (3) regulátorokat kódoló gének (Bhatnagar-Mathur et al. 2008). A növényi stressztürőképesség fokozása érdekében végzett (leginkább dohány) transzformációs kísérletekben az ún. egy funkciós géneket részesítik elönyben. Ide tartoznak például a következő ismert fukciójú stressz-indukált fehérjéket kódoló gének: a vízcsatorna-fehérjék génjei, az ozmolitok bioszintézisének (prolin, betain, trehalóz, poliamin) kulcsenzimeit kódoló gének, a detoxifikáló enzimek génjei és a transzport fehérjéket kódoló gének (Bhatnagar-Mathur et al. 2008). Tsvetkov és munkatársai (2000) például glicin-betain túltermelő növényeket állítottak elö a $V$. vinifera cv. 'Rusalka' fajta genetikai transzformációjával. Kísérleteikben három különböző génkonstrukciót használtak, melyek egy sarkvidéki hal fagyásvédő fehérje (anti-freeze) génjének szekvenciáit tartalmazták. Bár a metabolitok szintézisének módosításáért felelős gének

felhasználása egyszerübb - főleg ha a reakcióút ismert és kevés enzimreakciót igényel -, a stressztolerancia kialakításához számos gén egyidejü müködésére van szükség. Ezért a stressz-indukált gének harmadik csoportjába tartozó regulátor elemeket kódoló gének használata előtérbe került. Egyetlen stressz-indukált transzkripciós faktort kódoló gén felhasználásával - a termelődő fehérjék segítségével - a stresszválaszban résztvevő számos 
gén expressziója egyidejüleg szabályozható (Kasuga et al. 1999). A növényi stresszválaszban szerepet játszó transzkripciós faktorok száma szinte végtelen, a legnagyobb részük az AP/2/ERF, bZIP, NAC, MYB, MYC, Cys2His2 cink-ujj és a WRKY transzkripciós faktor családokhoz tartozik (Bartels and Sunkar 2005). Romero és munkatársai (1997) az optimális körülmények között nevelt, trehalózt túltermelő dohány növényeken fejődési rendellenességeket figyeltek meg, ezért a kiválasztott transzgén stresszrezisztenciában betöltött szerepén kívül - indukálható promóterek használatával - a génkifejeződés térbeli és időbeli szabályozása is döntő fontosságú lehet.

Stesszhatás következtében (magas fényintenzitás, ultraibolya B sugárzás, magas fémion koncentráció, magas vagy alacsony hőmérséklet, vízhiány, víztöbblet, sebzés, vírus-, baktérium-, és gombafertőzés) a reaktív oxigén fajták gyors akkumulációja (1. ábra) jelentősen hozzájárul a növényi terméskiesésekhez (Prince et al. 1989, Foyer et al. 1994, Hammond-Kosack and Jones 1996, Lamb and Dixon 1997). Reaktív oxigén fajták normál fiziológiai müködés esetén is képződhetnek a kloroplasztiszokban, mitokondriumokban és peroxiszómákban, semlegesítésük történhet enzimatikus (szuperoxid-dizmutáz, kataláz, gvajakol-peroxidáz) és nem enzimatikus (glutation, aszkorbinsav, karotinoidok, tokoferol) úton (Apel and Hirt 2004).

A képződött reaktív oxigén fajták különböző reakciókon keresztül egymásba átalakulhatnak, ennek egyik útja a Fenton-reakció, amikor a hidrogén-peroxid $\left(\mathrm{H}_{2} \mathrm{O}_{2}\right)$ szabad $\mathrm{Fe}^{2+}$ jelenlétében hidroxil gyökök forrása lehet: $\mathrm{H}_{2} \mathrm{O}_{2}+\mathrm{Fe}^{2+} \rightarrow \mathrm{OH}^{-}+\mathrm{OH}^{\circ}+\mathrm{Fe}^{3+}$. A Fenton-reakcióban keletkezett hidroxil gyök - amely a legkárosabb termelődő reaktív oxigénfajta - pedig kárt tud tenni a biológiailag fontos makromolekulák minden csoportjában, különösen a nukleinsavakban (Henle and Linn 1997).

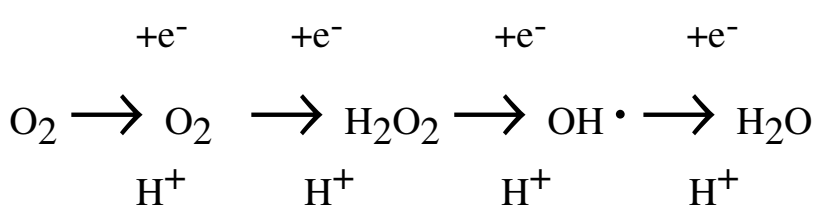

1. ábra: Az aktív oxigénformák képződésének folyamata az oxigén négyelektronos redukciója során (Scandalios 1990).

Mivel az intracelluláris vas katalizálja az oxidatív reakciókat, a szabad vas koncentrációjának szabályozása egy lehetséges módja lehet az oxidatív károk 
csökkentésének. Az élő szervezetekben széles körben elterjedt fehérje a ferritin (Theil 1987), egy burokba gyüjti a vasnak az élő sejtekben oldott állapotban jelenlévő formáját $\left(\mathrm{Fe}^{2+}\right)$, oxidálja is azt $\left(\mathrm{Fe}^{3+}\right)$, ezáltal a hidrogén-peroxid $\left(\mathrm{H}_{2} \mathrm{O}_{2}\right)$ nem jut elektronhoz. A ferritin fehérjekomplex a vasat oldható, különböző anyagcsere folyamatokban hasznosítható formában hordozza. A növényi ferritin elsősorban a kloroplasztiszokban lokalizált. A vegetatív szervek ferritin tartalma sokkal kisebb, mint a magvaké. A csírázás folyamán egyre csökken a ferritin mennyisége, ami feltehetőleg a fehérje 28 kDa-os alegységének szabad gyökök által történő oxidatív hasításának köszönhető (Lobréaux and Briat 1991). A növényi ferritin gének egy része konstitutív módon fejeződik ki, másik részének szintézisét viszont transzkripcionálisan szabályozza a vas, vagy a stresszhormon abszcizinsav (Lobréaux et al. 1993). A ferritin részvételét az oxidatív stresszválaszban humán és állati sejtkísérletekkel támasztották alá, amelyekben az oxidatív károk következtében a ferritin szintézis serkentése mutatkozott (Balla et al. 1992, Vile and Tyrrell 1993, Cario et al. 1995).

Deák és munkatársai (1999) lucerna cDNS könyvtárból stresszhatásra indukálódó ferritingént izoláltak, melyet Agrobacterium transzformációs vektorral juttattak be dohányba. CaMV 35S illetve Rubisco kis alegység promótereket és kanamicin rezisztencia-markert alkalmaztak. Mindkét promóter esetében azt várták, hogy erős kifejeződést mutat a transzformánsok vegetatív szöveteiben. A kanamicin rezisztens, feltételezett transzformáns dohány növények Northern blot analízise azt mutatta, hogy mindkét promóter esetén jelentős mennyiségü ferritin mRNS-t akkumuláltak a leveleikben. Ezeket a növényeket később a levelekből származó fehérjekivonat Western blot analízisével is jellemezték. A Rubisco kis alegység promóterhez kapcsolt gén 22,5kD molekulatömegü, aminovégi toldalékot nem tartalmazó érett fehérjeterméke a kloroplasztiszokban volt kimutatható. A CaMV 35S promóter esetében a lucerna ferritin cDNS szakaszához egy FLAG-tag kapcsolódott. Ezen transzformánsok esetében a 30 kDa molekulatömegü feldolgozatlan előfehérje-termék a citoplazmában volt kimutatható.

Előzetes kutatások szerint a vas toxicitás összefüggésben van az oxidatív stresszel (Kampfenkel et al. 1995). A paraquat herbicid a fotoszintetikus elektrontranszportláncból származó elektronok felhasználásával szuperoxidgyököket képez, ami a növények oxidatív károsodásához vezet (Babbs et al. 1989). Deák és munkatársai (1999) a kontroll és transzformáns dohány növényeket 4 napig $500 \mu \mathrm{M}$ koncentrációjú Fe(III)-EDTA és 2 napig $10 \mu \mathrm{M}$ koncentrációjú paraquat oldattal kezelték. A sejtkárosodás mértékét a fényindukált klorofill fluoreszcenciájának mérésével vizsgálták. A transzgénikus növények 
$\mathrm{F}_{\mathrm{v}} / \mathrm{F}_{\mathrm{m}}$ aránya az $500 \mu \mathrm{M} \mathrm{Fe}(\mathrm{III})$-EDTA hatására négy nap alatt 0,8-ról 0,6-0,7 körüli értékre, míg a kontroll dohánynövényeké 0,3-0,4 közé csökkent. A paraquat oldattal történő kezelés során a kontroll dohánynövények fotoszintetikus aktivitása szinte teljesen megszünt, míg a transzformáns vonalak mindegyike különböző mértékü toleranciát mutatott: $F_{\mathrm{v}} / F_{\mathrm{m}}$.arányuk és klorofilltartalmuk szignifikánsan magasabb értéket ért el. A ferritint túltermelő transzgénikus növények üvegházi körülmények között nem mutattak látható változást sem morfológiában, sem növekedési ütemben. Mivel a vas ion alapvető eleme a fotoszintetikus pigmenteknek, fontos hogy a ferritin túltermelés ne okozzon változást a fotoszintetikus aktivitásban és a kloroplasztisz összetételben a transzformáns növényeknél.

Reaktív oxigén fajták termelődnek kórokozók fertőzése során is, amikor egy bonyolult jelrendszeren keresztül (Low and Merida 1996) a kórokozó behatolás korlátozott (Peng and Kuc 1992, Ouf et al. 1993, Király et al. 1993) a növényi szövetek nekrotizálódása következtében (Elstner 1982, Sutherland 1991, Elstner and Osswald 1994, Baker and Orlandi 1995). Ebböl következik, hogy a növények antioxidáns kapacitásának növekedésével fokozódnia kellene a kórokozók által okozott sejt és szövet nekrózissal szembeni toleranciájuknak is; ezért az üvegházban nevelt 7 hetes kontroll és transzformáns dohány növényeket Deák és munkatársai (1999) tobacco necrosis vírussal (TNV) fertőzték. A nekrózisos foltok száma jelentősen csökkent a lucerna ferritint túltermelö transzformánsokban mindkét promóter esetében - a citoplazmában termelődött fehérje elhelyezkedési helyétől függetlenül - a kontroll növényekhez képest. Alternaria és Botrytis fertőzés esetén a nekrotikus foltok átmérőjét vizsgálva a transzformált vonalaknál szintén jelentős toleranciát figyeltek meg a kontroll növényekhez viszonyítva.

Hegedüs és munkatársai (2008) a lucerna ferritint kloroplasztidiálisan túltermelő transzgénikus dohány növényeket (Deák et al. 1999) az alacsony hőmérséklet okozta stressz hatások elemzésére használták fel. A négyleveles transzgénikus és nemtranszformált kontroll dohánynövényeket 24 órás megvilágítást, $200 \mu \mathrm{mol} \mathrm{m} \mathrm{m}^{-2} \mathrm{~s}^{-1}$ PPFD-t (fotoszintetikus fotonfluxus-sürüség) és $0^{\circ} \mathrm{C}$-os állandó hőmérsékletet biztosító Conviron PGV-36 nevelökamrába helyezték. A vizsgált transzgénikus vonalak $F_{v} / F_{m}$ értéke a két, illetve három napos hidegkezelés ideje alatt folyamatosan meghaladta a kontroll vonalak $\mathrm{F}_{\mathrm{v}} / \mathrm{F}_{\mathrm{m}}$ értékét. A hidegkezelést követően $22^{\circ} \mathrm{C}$-ra visszahelyezett transzgénikus növények esetében pedig ez az érték sokkal gyorsabban állt helyre, mint a kontroll növényeknél. Hideg és munkatársai (2000) vizsgálataik során azt tapasztalták, hogy az UV-B sugárzásnak és hosszú idejü (42 napos) szárazságkezelésnek kitett lucerna ferritint 
túltermelő dohánynövények károsodásának mértéke megegyezett a kontroll növények esetében tapasztalhatóval. Ezzel szemben Murgia és munkatársai (2001) az általuk vizsgált, fotoinhibíciós kezelésnek alávetett, szójaferritint plasztidiálisan túltermelő transzgénikus dohánynövények esetében az $\mathrm{F}_{\mathrm{v}} / \mathrm{F}_{\mathrm{m}}$ értékek nagyobb mértékü csökkenését mérték, mint a nem-transzformált növények esetében. A szójaferritint citoplazmatikusan túltermelő dohányok a nem-transzformált növényekkel megegyező mértékű károsodást mutattak.

Ha a különböző stesszhatások következtében képződött reaktív oxigén fajták reakcióba lépnek a lipidekkel, a képződött lipidperoxidok súlyos sejtszintű károsodást okozhatnak (Chia et al. 1984). A lipidperoxidok további degradációjával lipidaldehidek képződnek mind az állati, mind a növényi sejtekben. Ezen rendkívül mérgező hatású vegyületek közé tartozik a 4-hidroxinonenal (HNE), melynek aldehidcsoportját az aldózreduktázok képesek redukálni (Srivastava et al. 1995). Oberschall és munkatársai (2000) lucernából izolált, számos stresszhatásra indukálódó aldóz/aldehid-reduktáz génnel transzformáltak dohánynövényeket. Szárazságstressz hatására fotoszintetikus aktivitásukat csak az aldóz/aldehid-reduktáz enzimet túltermelő transzgénikus vonalak voltak képesek megőrizni, míg a nem transzgénikus növények újraöntözés hatására sem voltak képesek visszanyerni fotoszintetikus aktivitásukat. A transzformáns növények $\mathrm{H}_{2} \mathrm{O}_{2}$ - és $\mathrm{CdCl}_{2}$ kezeléssel szemben is ellenállóbbnak bizonyultak.

A növények oxidatív stresszel szembeni ellenállóságának növelése érdekében végzett transzformációs kísérletekben gyakran alkalmazzák a különböző szuperoxiddizmutáz (SODs) enzimeket kódoló géneket, mint pl. a citoplazmában lévő $\mathrm{Cu} / \mathrm{Zn}$ - SOD, a kloroplasztiszban lévő Fe-SOD vagy a mitokondriális Mn-SOD enzimek génjeit (Beyer et al. 1991). Tesniere és munkatársai (2006) szőlő transzformációs kísérleteikben az alkohol-dehidrogenáz enzim abiotikus stressz érzékenységben és másodlagos anyagcseretermékek szintézisében betöltött szerepét vizsgálták. Kísérleteikben a $V v A D H 2$ gén cDNS-ét szensz és antiszensz orientációban juttaták be a szomatikus embriókba. Az aldehid-dehidrogenázt túltermelő növényeknél alacsonyabb cukortartalomat, magasabb fenol és illóolaj tartalmat detektáltak.

\subsection{Agrobacterium rezisztens transzgénikus növények}

Az agrobaktérium okozta golyvás megbetegedés világszerte komoly problémákat okoz számos növényfaj esetében (pl. málna, szőlő, fás növények). A betegség 
kialakulásáért az A. tumefaciens vagy az A. vitis a felelős. A hidegebb klímájú termesztő területeken -mint például a magyarországi szőlőtermesztő vidékek- a szőlő agrobaktériumos megbetegedése különösen fontos. A probléma valamelyest csökkenthető Agrobacterium-mentes szaporítóanyag telepítésével, valamint rezisztens alanyfajták felhasználásával, azonban még nincs egy rutinszerüen alkalmazható és hatékony eljárás a szőlőtermesztők kezében, amivel a betegség megelőzhető lenne (Burr and Otten 1998).

Nam és munkatársai (1999) kiszelektáltak olyan mutáns Arabidopsis thaliana növényeket, amelyek rezisztensnek bizonyultak a tumoros megbetegedésre, azáltal, hogy a mutáció olyan géneket érintett, amelyek nélkülözhetetlenek az A. tumefaciens fertőzéshez és az onkogének integrációjához. A több tízezer lehetséges mutáns tesztelése kivitelezhető az Arabidopsis thaliana esetében, azonban ilyen nagyszámú mutáns előállítása és tesztelése a fás növényeknél - ahol az agrobaktériumos vesszőgolyva egy általános probléma - nem megvalósítható (Viss et al. 2003). Ezért elmondható, hogy a genetikai transzformáció az Agrobacterium okozta golyvás megbetegedés elleni rezisztencia kialakításában döntő szerephez juthat.

Sundberg és Ream (1999) élesztő kettős-hibrid rendszerben bizonyították, hogy az A. tumefaciens VirE1 fehérjéje kölcsönhatásba lép az Agrobacterium virulenciájában alapvető szerepet játszó VirE2 fehérjével. A VirE1 és VirE2 fehérje komplex kialakulásáról Deng és munkatársai (1999) azt feltételezik, hogy ez a kölcsönhatás a sejt aggregáció kialakulását és a VirE2 molekulák T-DNS-hez való kötődését hivatott megszüntetni a baktériumsejten belül. Ha a VirE1 fehérje már az Agrobacterium fertőzés elött jelen van a növényben, akkor a transzportálódó VirE2 fehérjék megkötése miatt a növényi sejtbe érkező T-DNS hozzáférhető lesz a növényi nukleázok számára (Szegedi et al. 2001). A két fehérje közötti kapcsolat megfelelő hatékonysága esetén pedig a tumorok kialakulása elmarad és az Agrobacterium elleni rezisztencia kialakulhat. Szegedi és munkatársai (2001) kísérleteik során az oktopinos A. tumefaciens törzs Ti-plazmidjáról (pTiA6) származó virE1 génnel transzformált dohány növényeket állítottak elő és a felnevelt növények golyvás megbetegedéssel szembeni ellenállóságát az A. vitis $\mathrm{AB} 3$ és $A$. tumefaciens A348 törzsekkel tesztelték. A független transzformáns növények vizsgálata során azt tapasztalták, hogy azokban a sejtekben, ahol a virEl gén kifejezödött csökkent a tumorok előfordulása az oktopinos A. vitis AB3 fertőzés során. Humann és munkatársai (2006) VirE1 fehérjét expresszáló transzgénikus Arabidopsis növényeket állítottak elő. A transzgénikus Arabidopsis és az üres vektorral transzformált kontroll vonalak $A$. tumefaciens A348 törzzsel való fertőzése során a transzgénikus Arabidopsis vonalak 
szignifikánsan rezisztensnek bizonyultak. A transzgénikus növényeken fejlődött tumorok 90\%-a 3 mm-nél kisebb, a kontroll növényeken fejlödött tumorok 44\%-a pedig 3 mm-nél nagyobb volt. Ezt követően a transzgénikus és kontroll növényekről származó tumorokat 11 hónapra hormonmentes MS táptalajra helyezték. A kontroll növényekről származó tumorok a legalább egyszeri szétdarabolást követően is 4-6 cm átméröjü differenciálatlan kallusz tömeggé fejlődtek, a transzgénikus vonalakról származó tumorok nagy része azonban elpusztult a táptalajon. A megmaradt tumorokat sem lehetett szétosztani, mert a kb. $2 \mathrm{~cm}$ átméröjü tumorok nem fejlődtek tovább. A kontroll vonalakkal ellentétben, a transzgénikus növényekről származó tumorokon fejlődött kalluszoknál gyökérfejlödést tapasztaltak. Rossi és munkatársai (1996) egy virE2 mutáns A. tumefaciens törzzsel való fertőzés során a fejlődött kisméretű tumorokban ún. csonkolt T-DNS-ek jelenlétét mutatták ki. Humann és munkatársai (2006) megfigyeléseik alapján szintén arra a következtetésre jutottak, hogy a transzgénikus növényekről származó tumorok sejtjei a virE1-VirE2 komlexképződés következtében a növényi nukleázok által megcsonkolt T-DNS-t tartalmazzák. Feltételezésüket a nem-patogén virE2 mutáns (MX358) és az A. rhizogenes GALLS nevü fehérjéjét kódoló plazmid (pLH338) felhasználásával támasztották alá. A GALLS fehérje nem homológ a VirE2 fehérjével, viszont képes helyettesíteni azt (Hodges et al. 2004). A pLH338 plazmidot hordozó MX358 virE2 mutáns törzzsel való fertőzés a kontroll és transzgénikus vonalak esetében hasonló mértékü tumor fejlődést eredményezett, tehát a transzgénikus vonalak rezisztenciája egyértelmüen a virE1 gén expressziójának volt köszönhető.

A tumorok kialakulásáért három integrálódó onkogén (iaaH, iaaM és ipt) által kiváltott auxin és citokinin túltermelés a felelős. Két onkogén olyan enzimet határoz meg, amelyek a triptofánt indol-3-ecetsavvá (Inzé et al. 1984) alakítják át: iaaM (triptofánmono-oxigenáz) és iaaH (indol-3-acetamid hidroláz). Az iaaH és iaaM onkogének által kódolt enzimek bármelyikének hiánya meggátolja az auxin termelést. A harmadik onkogén (ipt) pedig AMP izopentenil transzferázt kódol, amelyik izopentenil AMP-t (citokinint) állít elő (Winans 1992). Az ipt és iaaM vagy iaaH inaktiválása kikapcsolja a tumorgenezist (Lee et al. 2003). Az Agrobacterium esetében speciálisan alkalmazhatóak a poszttranszkripcionális génelhallgattatás (posttranscriptional gene silencing, PTGS) vagy RNS interferencia módszerei is, hiszen az Agrobacterium által beépített gének mRNS termékei megjelennek a baktérium által transzformált sejtekben.

A géncsendesítés egy mechanizmus, amely az eukarióta szervezetekben gének expresszióját képes módosítani (Baulcombe 2004). A folyamat során duplaszálú RNS 
(double stranded, dsRNS) indukálja a géncsendesítést. A Dicer nevü enzim a dsRNS molekulát a sejtben rövid, jellegzetes struktúrájú és méretü, hozzávetőlegesen 21 nukleotid hosszúságú darabokra vágja (small interfering RNS, siRNS). Ezekhez a rövid siRNS oligonukleotidokhoz kötődik az RNS indukálta géncsendesítő komplex (RNA induced silencing complex, RISC), ami a dsRNS két szála közül, valamilyen felismerő mechanizmus alapján kiválasztja az egyiket. Ez lesz a vezető szál, a másik pedig degradálódik. A kiválasztott szál segítségével a komplex szekvencia specifikusan ismeri fel az mRNS komplementer részét, majd azt a komplementer régió középen hasítja. Ennek következtében az mRNS degradálódik, így nem képződhet róla fehérje. A PTGS-t kiváltó transzgének jelenléte nem szükséges az összes sejtben, mivel a célzott gén csendesítése a nem transzformált sejtekben szisztemikusan is kiváltható (Voinnet et al. 1998). A PTGS szisztemizációját transzformált alany és transzformálatlan nemes között is megfigyelték (Palauqui et al. 1997).

Lee és munkatársai (2003) létrehoztak több génkonstrukciót az A. tumefaciens A348 törzsből származó iaaM és ipt szekvenciák segítségével, melyek készítésénél figyelembe vették, hogy az idő előtti stop kodont tartalmazó RNS molekulák destabilizáló hatása erősebb. Ezért az elrontani kívánt két gén esetében a harmadik kodont stop kodonra változtatták, és egyben egy „frame shift” mutációt is létrehoztak. Ehhez az iaaM génnek csak az első 1797 bázispár hosszú kódoló részét, az ipt génnek pedig a teljes kódoló szekvenciáját felhasználták. A két génből egy hibrid génkonstrukciót is létrehoztak úgy, hogy az ipt gén BamH1 helyére beépítették az iaaM kódoló részt. Az így elkészített konstrukciót egy növényi transzformációs vektorba építették, melyben a CaMV 35S promóterről egy irányban szensz RNS íródik át. A hibrid konstrukció, különösen az iaaM gén esetében, hatásosan müködött és akadályozta a tumorképződést. Az RNS hibridizációs kísérletekből kiderült, hogy az eredetileg egyszálú RNS átírására alkalmas vektor esetében a nopalin-szintáz promóteréről átíródott az antiszensz RNS is, így duplaszálú RNS is képződhetett, melyről ismert, hogy nagyobb mértékben aktiválja a géncsendesítés mechanizmusát. Ezt a jelenséget kihasználandó, készítettek egy olyan konstrukciót is, melyben a két gént egymás után építették, majd ezt két, egymással szemben elhelyezkedö, szensz és antiszensz RNS átírását biztosító promóter közé helyezték és növényi transzformációs vektorba juttatták. Ez a génkonstrukció a pJP17 nevet kapta, amelynek hatásosságát koinokulációs kísérletek segítségével bizonyították. A koinokulációs teszt során a pJP17 konstrukciót tartalmazó törzset és a patogén baktériumot összekeverve kalanchoe növényeket vagy burgonya korongokat fertőztek. A teszt lényege, hogy a 
géncsendesítésre tervezett konstrukció és a patogén T-DNS egyaránt bejut a fertőzött sejtekbe, és így a vektor tumorképzést megakadályozó hatása transzgénikus növények létrehozása nélkül, azonnal vizsgálható. Mivel nem minden sejtbe jut be mindkét vektor, tumorképződés is megfigyelhető, csak csökkent mértékben. Lee és munkatársai (2003) kísérleteikben azt is bizonyították, hogy a géncsendesítés létrejöttéhez szükség van a gén transzlációs start szekvenciájára is, e nélkül hiába tartalmazza a konstrukció akár a teljes gén 90\%- át, a csendesítés nem jön létre. A géncsendesítés abban az esetben is hatástalan, ha nincs megfelelő szekvencia azonosság a vektorral bejuttatott gén és a patogén Agrobacterium T-DNS részén elhelyezkedő gén között, hiszen a folyamat alapja a szekvencia specifikusan történő felismerés. Ebből következik, hogy ez a módszer nem általánosítható minden Agrobacterium törzsre, mert az iaaM szekvenciák nagyon eltérőek, még a közeli rokon törzsek esetében is. Galambos Anikó diplomadolgozatában (2007) számítógépes elemzés segítségével összehasonlította néhány Agrobacterium törzs iaaM génjének szekvenciáját, majd ennek alapján elkészítette a rokonsági viszonyokat ábrázoló törzsfát is (2. ábra). Ahogy az az ábrán is látszik, az A. tumefaciens S4 a többi törzstől teljesen elkülönülten, önnálló ágon helyezkedik el, így feltehetően a pJP17 vektorkonstrukció ezzel a törzzsel szemben hatástalan.

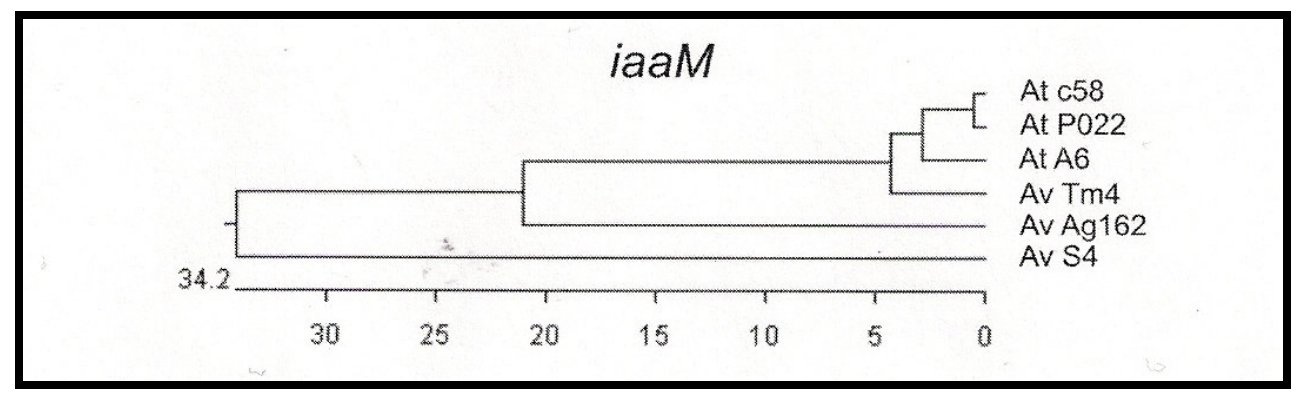

2. ábra: A különböző Agrobacterium törzsek iaaM DNS-szekvenciáinak összehasonlításából származó törzsfa. At: Agrobacterium tumefaciens törzsek, Av: Agrobacterium vitis törzsek (Galambos 2007)

A szőlő esetében azonban jelentős kórokozó az A. vitis S4 törzs, amelynek iaaM szekvenciája jelentősen eltér a többi Agrobacterium törzsétől, ezért a Pécsi Tudomány Egyetem Biológiai Intézetének Genetika és Molekuláris Biológiai Tanszékén (Galambos 2007) a PCR technika segítségével izolálták az A. vitis S4 törzs iaaM génjének egy részletét, majd számos klónozási lépésen keresztül hozzákapcsolták azt az A. tumefaciens iaaM génből származó szakaszhoz. Az így létrehozott T-DNS konstrukciót (pJP17-S4) 
megfelelő (,disarmed”) A. tumefaciens törzsbe juttatva kalanchoe koinokulációs és dohány transzformációs kísérletekben tesztelték.

Viss és munkatársai (2003) az agrobaktérium transzformációs rendszert alkalmazva két különböző génkonstrukciót (pJP17, pJP20) használtak fel a géncsendesítés mechanizmusának indukálásához a 'Jonagold' almafajtában. Az előző bekezdésben ismertetett pJP17 konstrukció esetében a két egymással szemben elhelyezkedő, szensz és antiszensz RNS átírását biztosító promóter közé helyezett, egymás után épített iaaM és ipt géneket növényi transzformációs vektorba juttatták. A pJP20 plazmid esetében a két gén szeparáltan helyezkedett el, mindegyik a normál és az inverz átírást biztosító promóterekkel körülvéve. Az ötven regenerált és bizonyítottan transzformáns alma vonal közül kiválasztottak 14 vonalat a további tesztelésekhez. Ezek közül négy vonal a pJP17, tíz pedig a pJP20 génkonstrukciót hordozta. Mivel a tumoros megbetegedés általában a gyökéren jelentkezik, ezért a transzformáns növényekböl származó gyökérkorongokat (vonalanként legalább 180 explantátum) fertőzték az A. tumefaciens A348 törzzsel. Három hónappal a fertőzés után hat vonal esetében egyáltalán nem találtak tumorfejlődést. A rezisztens vonalak közül három a pJP17, a másik három pedig a pJP20 konstrukcióval volt transzformálva. Kísérleteik során mindkét konstrukció alkalmasnak bizonyult almában az iaaM onkogén csendesítésére.

A lehetséges megoldások közé tartozik még a speciális antibakteriális fehérjék termeltetése ( $\mathrm{pl}$. a bakteriális membránt, sejtfalat vagy anyagcserét károsító peptidek), a bakteriális toxinok gátlása (pl. a toxint inaktiváló fehérje termeltetésével), izolált növényi rezisztenciagének felhasználása vagy az oxidatív stressz okozta károsodás mérséklése (Dudits és Heszky, 2003). Azonban figyelembe kell venni azt is, hogy a lítikus peptidek toxikusak lehetnek a növények és emlős állatok sejtjeire, egy ilyen növény felboríthatja a mikroflóra természetes egyensúlyát.

\subsection{Az in vitro körülmények és az akklimatizáció hatékonysága közötti összefüggések}

A mikroszaporítás a legelterjedtebb szaporítási technika, amely lehetőséget nyújt a nemesítési programok során szelektált növények gyors felszaporítására. Az in vitro tenyésztés minden szakasza hatással van a szaporulatok számára és minőségére, de a legvégső siker leginkább a növények gyökereztetésén, edzésén és akklimatizálásán múlik, amelynek magas túlélési arányt és megfelelő ex vitro fejlődést kell eredményeznie. 
A steril körülmények között előállított mikrodugványok gyökereztetése elvégezhető in vitro vagy ex vitro körülmények között (McCown 1988). Az in vitro gyökereztetés steril körülmények között zajlik, az ex vitro gyökereztetéssel ellentétben. In vitro gyökereztetéshez általában agarral szilárdított táptalajt használnak, ebbe helyezik a hajtásokat a gyökér iniciációhoz és a gyökér elongációhoz is. Használható külön auxintartalmú táptalaj a gyökér iniciációhoz, majd egy auxinmentes táptalaj a gyökér elongációhoz. Az in vitro növények növényházba történő áthelyezéséhez, valamint talajba ültetéséhez a gyökereztető közeg teljes eltávolítására van szükség, hogy megelőzzük a fertőzéseket. Az agarral szilárdított táptalajban fejlödött gyökerek vékonyak, törékenyek és általában sérülnek a mosás során, pedig a müködőképes gyökérrendszer megléte az egyik legfontosabb feltétele annak, hogy a növény vizet és ásványi anyagokat tudjon felvenni és megfelelő módon reagáljon a stresszhatásokra kiültetés után, üvegházi vagy szabadföldi körülmények között (Nowak and Shulaev 2003).

A gyökeresedés, valamint a növényházi körülményekhez történő alkalmazkodás hatékonyságának növelésére Roberts és munkatársai (1990, 1994) cellulóz alapú (Sorbarod) közeget, Roche és munkatársai (1996) habot, Rugini és Verma (1982) vermikulitot, Jay-Allemand és munkatársai (1992) vermikulit és gerlit keveréket, Gebhardt és Friedrich (1987) tőzeget, Gangopadhyay és munkatársai (2002) pedig kókuszrostot alkalmaztak. A gyökeres mikrodugványokat minden esetben cserépben nevelték tovább üvegházi körülmények között.

A szőlő in vitro szaporítása napjainkban egy megalapozott és rutinszerüen alkalmazható eljárásnak számít (Torregrosa et al. 2001), azonban a gyökereztetés és az akklimatizáció hatékonysága még mindig nem megfelelő az általában agarral vagy gerlitetel szilárdított közegekben fejlődő gyökerek törékenysége, valamint a kiültetés utáni befertőződési problémák miatt. Torregrosa és munkatársai (2001), valamint Gribaudo és munkatársai (2003) az akklimatizáció hatékonyságának növeléséhez inorganikus folyadék használatát, fokozatos szellőztetést, illetve jól szellőző edények használatát javasolják. 


\section{ANYAG ÉS MÓDSZER}

\subsection{Felhasznált anyagok}

\subsubsection{Felhasznált növények}

Kísérleteink során az 'Arany sárfehér', 'Cabernet franc', 'Odysseus', 'Orpheus', 'Taurus', 'Chardonnay', 'Kékfrankos', 'Korai Bíbor', 'Pannon frankos', 'Rajnai rizling' nemes-, és a 'Teleki 5C', 'Richter 110' alanyfajtákkal dolgoztunk, amelyeket a Budapesti Corvinus Egyetem Genetika és Növénynemesítés Tanszéke, valamint a Budapesti Corvinus Egyetem Szőlészeti és Borászati Kutató Intézete (Kecskemét) bocsátott a rendelkezésünkre.

5.1.2. Felhasznált transzformációs vektorok

\begin{tabular}{|c|c|c|c|}
\hline $\begin{array}{c}\text { baktériumtörzsek és } \\
\text { plazmidok }\end{array}$ & $\begin{array}{c}\text { jellemzö } \\
\text { tulajdonságok }\end{array}$ & irodalom & származás \\
\hline EHA105 (pEHA105+pRok2) & $\begin{array}{c}\text { pTiBo542-ből } \\
\text { származó onc-plazmid, } \\
\text { Kmr }\end{array}$ & $\begin{array}{c}\text { Deák et al. } \\
1999\end{array}$ & $\begin{array}{l}\text { BCE SzBKI, } \\
\text { Kecskemét }\end{array}$ \\
\hline $\begin{array}{c}\text { EHA105 } \\
\text { (pEHA105+pRok2Ferr) }\end{array}$ & $\begin{array}{c}\text { pTiBo542-ből } \\
\text { származó onc-plazmid, } \\
\text { Kmr }\end{array}$ & $\begin{array}{c}\text { Baulcombe et } \\
\text { al. } 1986 \\
\text { Deák et al. } \\
1999\end{array}$ & $\begin{array}{l}\text { BCE SzBKI, } \\
\text { Kecskemét }\end{array}$ \\
\hline $\begin{array}{c}\text { EHA105 } \\
\text { (pEHA105+pRok2FerrFLAG) }\end{array}$ & $\begin{array}{c}\text { pTiBo542-böl } \\
\text { származó onc-plazmid, } \\
\text { Kmr }\end{array}$ & $\begin{array}{l}\text { Deák et al. } \\
1999\end{array}$ & $\begin{array}{l}\text { BCE SzBKI, } \\
\text { Kecskemét }\end{array}$ \\
\hline $\begin{array}{c}\text { EHA101 } \\
\text { (pEHA101+pTd93virE1) }\end{array}$ & $\begin{array}{c}\text { pTiBo542-ből } \\
\text { származó onc-plazmid, } \\
\text { Kmr, Gmr }\end{array}$ & $\begin{array}{l}\text { Szegedi et al. } \\
2001\end{array}$ & $\begin{array}{l}\text { BCE SzBKI, } \\
\text { Kecskemét }\end{array}$ \\
\hline EHA101 (pEHA101+pJP17) & $\begin{array}{c}\text { pTiBo542-ből } \\
\text { származó onc-plazmid, } \\
\text { Kmr, Gmr }\end{array}$ & $\begin{array}{l}\text { Viss et al. } \\
2003\end{array}$ & $\begin{array}{l}\text { BCE SzBKI, } \\
\text { Kecskemét }\end{array}$ \\
\hline EHA101 (pEHA101+pJP17-S4) & $\begin{array}{c}\text { pTiBo542-ből } \\
\text { származó onc-plazmid, } \\
\text { Kmr, Gmr }\end{array}$ & $\begin{array}{l}\text { Galambos } \\
2007\end{array}$ & $\begin{array}{l}\text { BCE SzBKI, } \\
\text { Kecskemét }\end{array}$ \\
\hline
\end{tabular}

\subsubsection{A transzformációs vektorok ismertetése}

Az általunk felhasznált pRok2Ferr, pRok2FerrFLAG és pRok2 plazmidok (3. ábra) a Magyar Tudományos Akadémia Szegedi Biológiai Központjának Növénybiológiai 
Intézetéből származnak, és a Budapesti Corvinus Egyetem Szőlészeti és Borászati Kutató Intézete (Kecskemét) bocsátotta őket a rendelkezésünkre. A pRok2Ferr plazmid T-DNS tartalmazza a nopalin-szintáz gén (nos) promóterének kontrollja alatt álló nptII (neomicinfoszfo-transzferáz) szelekciós markergént és a lucerna ferritin gént. A ferritin gén müködését az elé beépített karfiol mozaikvírus CaMV 35S promóter szekvenciája irányítja. A plazmid bakteriális szelekciós génként kanamicin rezisztenciát biztosít a baktérium számára. Deák és munkatársai (1999) bizonyították, hogy a gén kezdő szakasza felelős a fehérjetermék kloroplasztiszban történő megnyilvánulásáért. A pRok2FerrFLAG plazmid konstrukció esetében a lucerna ferritin cDNS szakaszához egy FLAG-tag kapcsolódik, ezért a termelödő fehérje feldolgozatlan formában a citoplazmában marad. A pRok2 plazmid konstrukció hordozza az CaMV 35S promóter irányítása alatt álló uidA (gus) és a nopalin-szintáz gén (nos) promóterének kontrollja alatt álló nptII (neomycin-foszfotranszferáz) géneket. A Medicago sativa-ból származó MsFerr gén teljes szekvenciája az X 97057 szabadalmi szám alatt került be az Európai Molekuláris Biológiai Laboratórium (EMBL) adatbankjába.

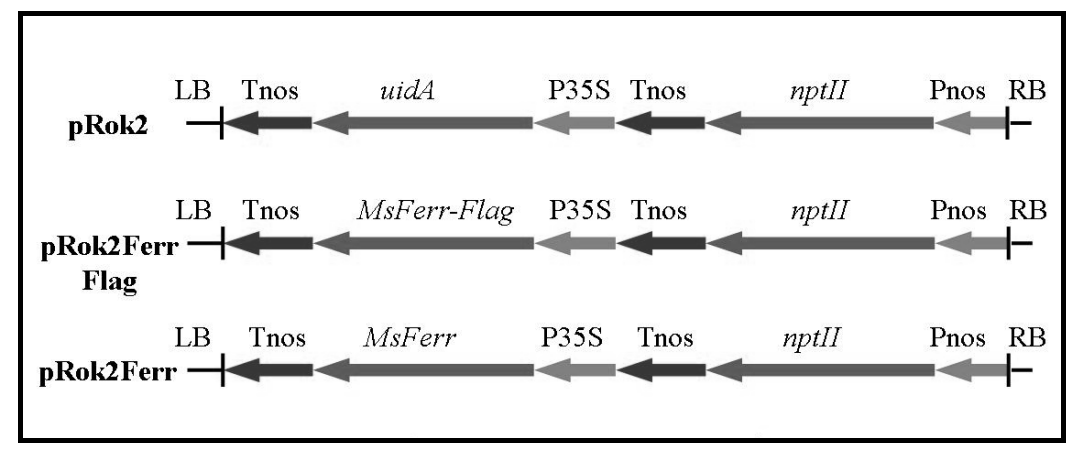

3. ábra: A pRok2, pRok2FerrFLAG és pRok2Ferr plazmidok T-DNS-ének vázlatos bemutatása.

RB, LB: jobb és baloldali határoló régiók, Pnos: nopalin-szintáz gén promóter régiója, Tnos: nopalin-szintáz gén terminációs régiója, P35S: karfiol mozaikvírus CaMV 35S promóter szekvenciája (Deák et al. 1998 nyomán).

A pTd93virE1 plazmid Bruno Tinland-tól származik (ETH Zentrum, Zürich, Svájc), és szintén a Budapesti Corvinus Egyetem Szőlészeti és Borászati Kutató Intézete (Kecskemét) bocsátotta azt a rendelkezésünkre. A konstrukció hordozza az CaMV 35S promóter irányítása alatt álló nptII (neomycin-foszfo-transzferáz) és az A. tumefaciens virE1 géneket (4. ábra). A plazmid bakteriális szelekciós génként gentamicin rezisztenciát biztosít a baktérium számára. 


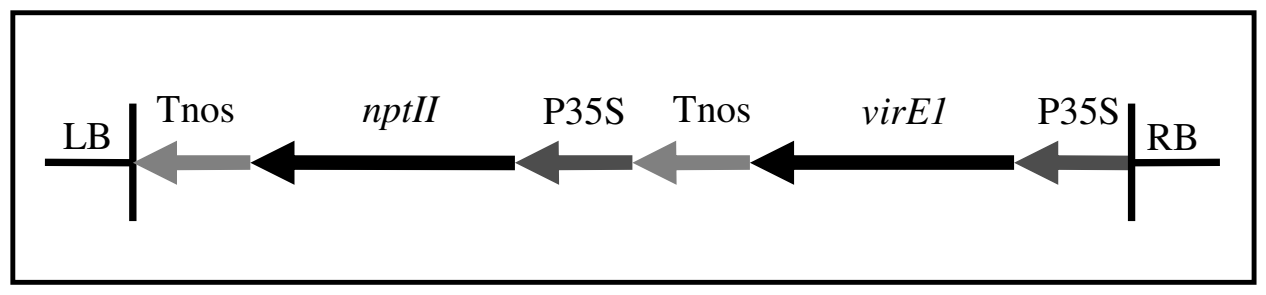

4. ábra: A pTd93virE1 plazmid T-DNS vázlatos bemutatása.

RB, LB: jobb és baloldali határoló régiók, nptII: neomicin foszfotranszferáz gén, Tnos: nopalin-szintáz gén terminációs régiója, P35S: karfiol mozaikvírus CaMV 35S promóter szekvenciája (Szegedi et al. 2001 nyomán).

A pJP17 konstrukciót Walter Ream (Oregon State University, USA) a Monsanto hozzájárulásával bocsátotta a Budapesti Corvinus Egyetem Szőlészeti és Borászati Kutató Intézetének (Kecskemét) rendelkezésére. A konstrukció a két csendesíteni kívánt (A348) onkogénnek, az iaaM génnek az első 1797 bázispár hosszú kódoló részét, az ipt génnek pedig a teljes kódoló szekvenciáját tartalmazza. Mindkét gén esetében a harmadik kodont stop kodonra változtatták, és egyben egy „frame shift” mutációt is létrehoztak. A két gént egymás után építették, majd ezt két, egymással szemben elhelyezkedő, szensz és antiszensz RNS átírását biztosító promóter közé helyezték (5. ábra). A plazmid bakteriális szelekciós génként gentamicin rezisztenciát biztosít a baktérium számára.

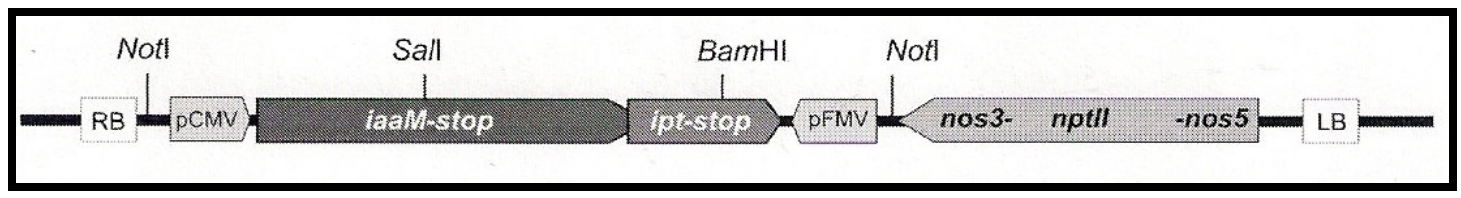

5. ábra: A pJP17 konstrukció T-DNS része (Galambos 2007).

RB, LB: jobb és baloldali határoló régiók, nptII: neomicin foszfotranszferáz gén, nos3' és nos5': nopalin-szintáz 3' és 5' szekvencia, pCMV és pFMV növényi promóterek, NotI, Sall és BamHl: enzimek hasítóhelyei.

Az A. vitis S4 iaaM szekvenciát is tartalmazó pJP17-S4 konstrukció a pJP17 konstrukció átalakított változata azáltal, hogy a 6. ábrán feltüntetett SalI és BamHI fragment helyére történt az új szekvencia beillesztése. A plazmid bakteriális szelekciós génként gentamicin rezisztenciát biztosít a baktérium számára. A pJP17-S4 konstrukciót Galambos Anikó (PTE TTK Biológiai Intézet Genetika és Molekuláris Biológiai Tanszék, Pécs) állította elő Szegedi Ernővel (BCE Szőlészeti és Borászati Kutató Intézet, Kecskemét) együttmüködésben. 
Az pTd93virE1, pJP17 és pJP17-S4 vektorokkal végzett munkát Szegedi Ernő (BCE Szőlészeti és Borászati Kutató Intézet, Kecskemét) felügyelete alatt végeztük.

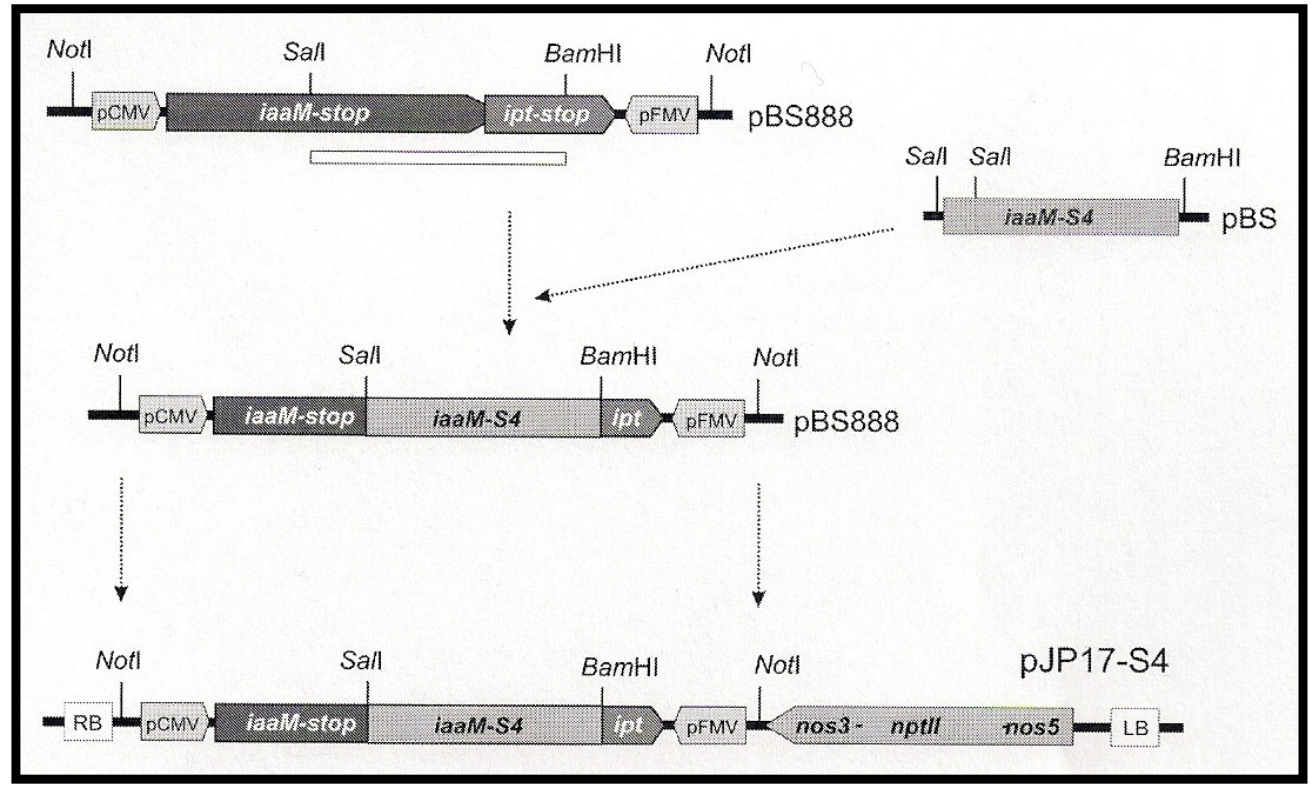

6. ábra: A pJP17-S4 konstrukció T-DNS része (Galambos 2007).

RB, LB: jobb és baloldali határoló régiók, nptII: neomicin foszfotranszferáz gén, nos3' és nos5': nopalin-szintáz 3' és 5' szekvencia, pCMV és pFMV növényi promóterek. NotI, Sall és BamHl: enzimek hasítóhelyei.

\subsection{Alkalmazott módszerek}

\subsubsection{Embriogén kallusz indukció}

Az embriogén kallusz indukálását 12 különböző szőlőfajta portok tenyészetein kíséreltük meg. Az 'Arany sárfehér', 'Cabernet franc', 'Odysseus', 'Orpheus', 'Taurus', 'Richter 110' fajták embriogén kapacitását két különböző táptalajon (MSE, MST); a 'Chardonnay', 'Kékfrankos', 'Korai Bíbor', 'Pannon frankos', 'Rajnai rizling', 'Teleki 5C' fajták embriogén kapacitását pedig négy különböző táptalajon (MSE, MST, MSE/2, NNE) teszteltük. A felhasznált MS alapú táptalajok (MSE, MSE/2, MST) a Murashige és Skoog (1962) által leírt komponensek mellett 20 g/l szacharózt, 70 mg/l Fe-EDTA-t és $7 \mathrm{~g} / 1$ Oxoid agart tartalmaztak (pH 5,8). Az (1.) MSE táptalaj (Mozsár and Süle, 1994) 0,1 mg/l BA-t és 1,1 mg/l 2,4-D-t tartalmazott, az (2.) MSE/2 egy módosított MSE táptalaj, amely fele koncentrációban tartalmazta a makroelemeket, az (3.) MST táptalaj (Oláh et al. 2003a) pedig 0,05 mg/l TDZ-t és 1,1 mg/1 2,4-D-t tartalmazott. Az (4.) NNE táptalaj a Nitsch és 
Nitsch (1969) által leírt táptalaj, amely az $1,1 \mathrm{mg} / \mathrm{l} \quad 2,4-\mathrm{D}$ és $\quad 0,1 \mathrm{mg} / \mathrm{l} \quad \mathrm{BA}$ hormonkombinációt tartalmazta.

Az embriogén kultúra indításához a portokokat a szabadföldi növények, illetve a szabadföldről begyüjtött és üvegházban hajtatott vesszők még zárt virágbimbóiból nyertük. Hajtatáshoz a beérett vesszőket november-decemberben gyüjtöttük be szabadföldröl, majd $4^{\circ} \mathrm{C}$-os vernalizációs kezelést követően a vesszőket szakaszosan (januártól májusig), kétrügyes dugványra vágva helyeztünk a perlittel megtöltött konténerekbe (7. ábra). A csapvízzel nedvesített perlitben lévő vesszőkről a 2-3 hét után megjelent leveleket naponta eltávolítottuk, hogy egyéb fotoszintetizációs felület hiányában a virágfejlödést indukáljuk. Ezzel a módszerrel a vesszők perlitbe helyezését követően körülbelül 5 hét után kapunk az embriogén kallusz indukciós kísérletekhez megfelelő stádiumú (III. és IV., Gribaudo et al. 2004) virágzatokat. A vesszők hajtatását a munkacsúcs széthúzása, valamint az üvegházi körülmények között nevelt növények nagyobb hatékonyságú sterilizációja miatt alkalmaztuk. Nem elhanyagolható az a különbség sem, hogy az üvegházban hajtatott vesszők nincsenek kitéve az időjárás viszontagságainak a virágzás idején, szemben az ültetvényben lévő tőkékkel. 


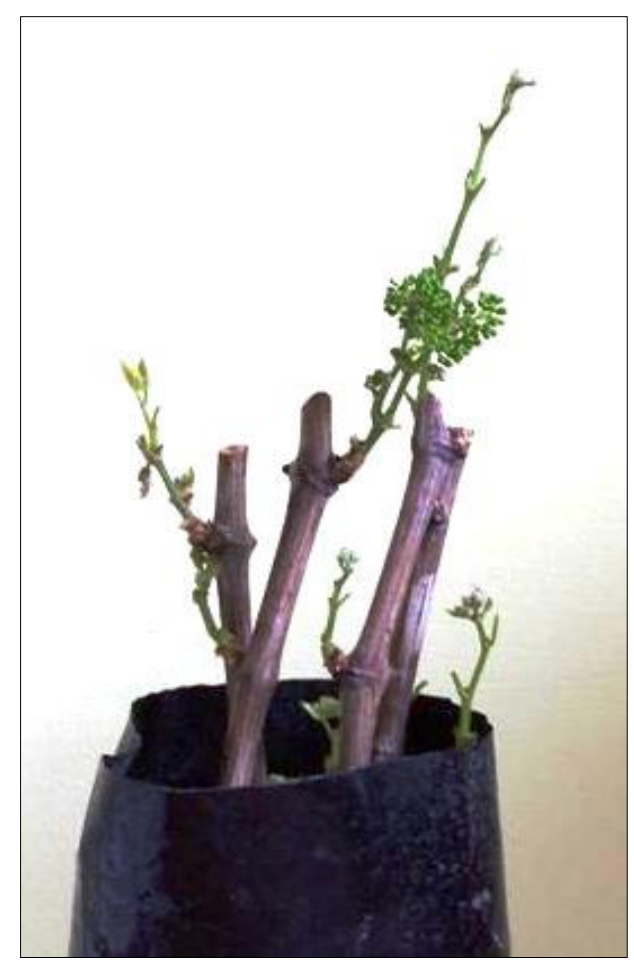

7. ábra: Üvegházi körülmények között perlitben hajtatott ‘Chardonnay’ vesszők.

A közvetlenül virágzás előtt begyüjtött, közel azonos fenofázisban lévő virágzatokat 7 napig $4^{\circ} \mathrm{C}$-on, hütőben tároltuk. A virágbimbókat $0,6 \%$-os $\mathrm{NaOCl}$ oldatban 10 percig fertőtlenítettük, majd háromszor 10 percre desztillált vízbe merítettük. A virágot (esetenként sztereómikroszkóp alatt) lándzsatü és csipesz segítségével bontottuk szét, a portokokat az eljárás során steril csapvízzel nedvesítve. A kipreparált portokokat portoknyéllel együtt helyeztük a táptalajra. Az embriogén kallusz indukciós kísérleteket 6 ismétlésben végeztük el, egy Petri-csészébe kb. 50 db portok került. A kultúrákat indítás után $26^{\circ} \mathrm{C}$-on sötétben inkubáltuk. A három hónapos inkubációs időt követően a portokon megjelent kalluszt értékeltük.

Kísérleteink során felmerült, hogy a sterilizáció módja hatással lehet az embriogén kallusz indukcióra, ezért a hajtatott ‘Chardonnay’ vesszőkről begyüjtött virágzatokat 7\%os $\mathrm{Ca}(\mathrm{OH})_{2}$ oldatban illetve $0,6 \% \mathrm{NaOCl}$ oldatban (Chlorox 15\%) fertőtlenítettük. A sterilizációt követően a virágzatokból kipreparált portokokat mindkét sterilizációs eljárást követően négy különböző táptalajra helyeztük: (1.) MSE; (2.) MSEC, amely egy módosított MSE táptalaj 2,5 g/l aktív szénnel kiegészítve; (3.) MSE táptalaj, amely $4 \mathrm{~g} / 1$ polyvinylpyrrolidont (Policlar AT, Perl et al. 1996; Mozsár et al. 1998) és 0,1 g/l 
dithioerythritolt (Bornhoff and Harst 2000) tartalmazott; (4.) CPE amely a Cheé és Pool (1987) által leírt szőlöre optimalizált táptalaj 0,1 mg/l BA-nel és 1,1mg/l 2,4-D-vel kiegészített változata. A kísérletet 10 ismétlésben végeztük el, és a portokokon megjelent kalluszt három hónap elteltével értékeltük. Az 1. táblázat összefoglalóan tartalmazza az embriogén kallusz indukciós kísérletekben felhasznált táptalajokat.

1. táblázat: Felhasznált táptalajok.

\begin{tabular}{|c|c|c|c|c|c|}
\hline Táptalaj & $\begin{array}{c}\text { Alap- } \\
\text { táptalaj }\end{array}$ & Szénforrás & $\begin{array}{c}\text { Makroelemek } \\
\text { (konc.) }\end{array}$ & $\begin{array}{c}\text { Mikroelemek } \\
\text { (konc.) }\end{array}$ & $\begin{array}{c}\text { Növekedés- } \\
\text { szabályozók }\end{array}$ \\
\hline MS/2 & $\begin{array}{c}\text { Murashige } \\
\& \text { Skoog }\end{array}$ & szacharóz & fél & teljes & - \\
\hline MSE & $\begin{array}{c}\text { Murashige } \\
\& \text { Skoog }\end{array}$ & szacharóz & teljes & teljes & BA, 2,4-D \\
\hline MSE/2 & $\begin{array}{c}\text { Murashige } \\
\& \text { Skoog }\end{array}$ & szacharóz & fél & teljes & BA, 2,4-D \\
\hline MST & $\begin{array}{c}\text { Murashige } \\
\& \text { Skoog }\end{array}$ & szacharóz & teljes & teljes & TDZ, 2,4-D \\
\hline MSNOA & $\begin{array}{c}\text { Murashige } \\
\& \text { Skoog }\end{array}$ & $\begin{array}{c}\text { maltóz, } \\
\text { glicerin }\end{array}$ & teljes & teljes & NOA \\
\hline CP & $\begin{array}{c}\text { Cheé \& } \\
\text { Pool }\end{array}$ & szacharóz & teljes & teljes & - \\
\hline CPE & $\begin{array}{c}\text { Cheé \& } \\
\text { Pool }\end{array}$ & szacharóz & teljes & teljes & BA, 2,4-D \\
\hline NN & $\begin{array}{c}\text { Nitsch \& } \\
\text { Nitsch }\end{array}$ & szacharóz & teljes & teljes & - \\
\hline NNE & $\begin{array}{c}\text { Nitsch \& } \\
\text { Nitsch }\end{array}$ & szacharóz & teljes & teljes & BA, 2,4-D \\
\hline
\end{tabular}

\subsubsection{Az embriogén kallusz felszaporítása}

Oláh és munkatársai (2008) kísérleteikben az 1,1 mg/l 2,4-D-t és 0,1 mg/l BA-t tartalmazó MSE táptalajt találták legmegfelelöbbnek a portokon fejlődött embriogén kallusz felszaporítására, ezét mi is ezt a táptalajt használtuk erre a célra. Emellett a 'Richter 110' alanyfajta esetében kipróbáltuk az 1,1 mg/l 2,4-D-t és 0,1 mg/l BA-t tartalmazó CPE táptalajt embriogén kallusz felszaporítására. A kísérletben kontollként az azonos hormonkombinációt tartalmazó MSE táptalajt használtuk, majd az 1. és 2. hónap után megmértük a folyamatosan osztódó kallusz tömegét. A kapott eredményeket egytényezős variancia-analízissel értékeltük. 


\subsubsection{Szomatikus embrió indukció és növényregeneráció}

A portok eredetü és felszaporított embriogén kalluszt 10 g/l szacharózzal és $7 \mathrm{~g} / 1$ agarral kiegészített szilárd hormonmentes MS/2 táptalajra (1. táblázat) helyeztük, hogy szomatikus embriófejlődést inukáljunk (sötétben $26^{\circ} \mathrm{C}$-on). Egy hónap elteltével a szilárd táptalajon lévő kultúrákat egy hétre fényre helyeztük, majd a csírázó embriókat egyesével $30 \mathrm{ml}$ hormonmentes $\mathrm{MS} / 2$ táptalajt tartalmazó üvegfiolákban neveltük tovább $24^{\circ} \mathrm{C}$-on 16 órás megvilágítás mellett. Ezt követően kb. három hónapon belül a regenerálódott, gyökérrel és hajtással rendelkező 4-5 leveles szőlő növények felszaporíthatók.

\subsubsection{A növényregenerációs kísérletek optimalizálása}

A 'Teleki 5C', 'Richter 110' és 'Chardonnay' fajták esetében a portok eredetü embriogén kalluszt folyékony MSNOA táptalajban (1. táblázat) kívántuk homogenizálni. A kísérletben az $5 \mu \mathrm{M}$ NOA hatását teszteltuik, a táptalaj a Mauro és mtsai (1995) által leírt mennyiségű maltózt és glicerint tartalmazta. A folyékony táptalajban felszaporított homogén kalluszt 2 hét sötétben történő rázatást követően hormonmentes MS/2 helyeztük. A kísérlethez kontrollként az 1,1 mg/l 2,4-D-t és 0,1 mg/l BA-t tartalmazó szilárd MSE táptalajról származó embriogén kalluszt használtuk, mindhárom fajtánál MS/2 táptalajon vizsgáltuk az embriogén anyag további fejlödését, összevetve a folyékony MSNOA táptalajban homogenizált embriogén kallusz regenerációjával.

Ezen kívül a 'Chardonnay' fajta esetében az 1,1 mg/l 2,4-D-t és 0,1 mg/l BA-t tartalmazó szilárd MSE táptalajról származó embriogén kallusz regenerációját hormonmentes MS/2 és CP (1. táblázat) táptalajokon hasonlítottuk össze, a regenerációs idő hosszát figyelembe véve.

\subsubsection{Szőlő direkt organogenezis}

Szőlő organogenezist célzó kísérleteinkben a rügy eltávolítása után a rügyalap sejtjeiből próbáltunk hajtást regenerálni citokinin típusú hormonok segítségével. A kísérletben az in vitro körülmények között nevelt 'Richter 110' alanyfajtát teszteltük. Egyrügyes mikrodugványokat készítettünk (8a. ábra) és a levélhónaljakban található szemeket kipattintottuk (8b. ábra). A rügy eltávolítását mikroszkóp alatt ellenőriztük. A mikrodugványokat merőlegesen helyeztük a két különböző hormonnal - (1.) 0,1 mg/l BA illetve (2.) 0,25 mg/l TDZ - kiegészített szilárd MS táptalajra. 

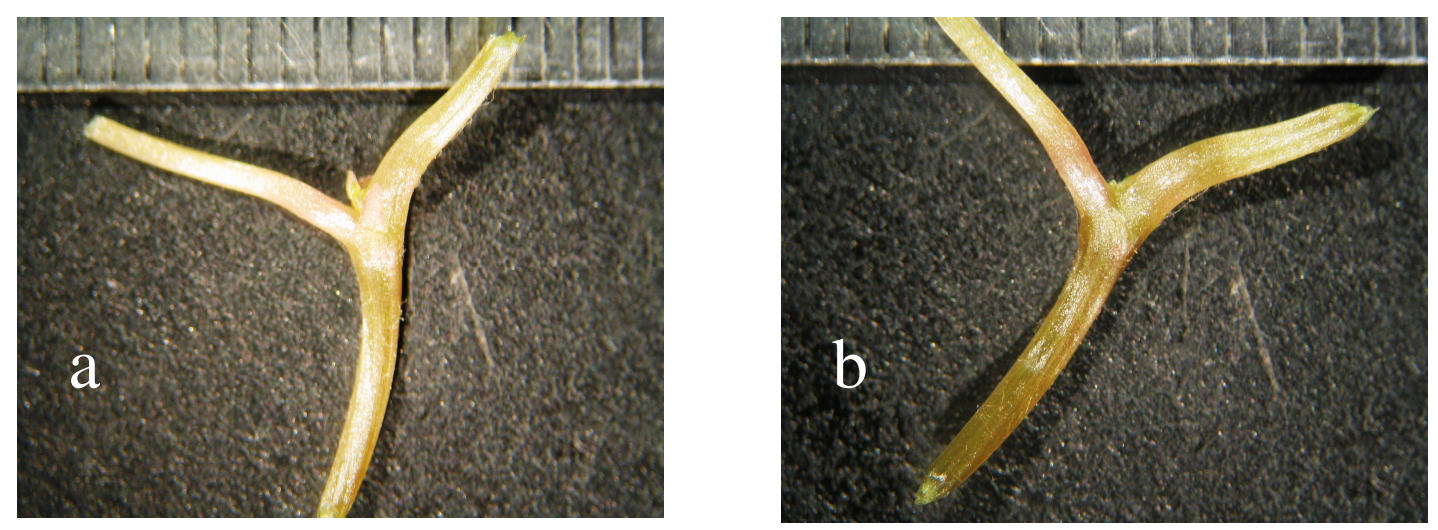

8. ábra: A szőlő organogenezishez felhasznált egyrügyes (a) és kivakított (b) mikrodugvány.

\subsubsection{Szőlőtranszformáció}

5.2.5.1. Embrió fejlődés indukálása és agrobaktériumos kezelés

A 'Richter 110' portokokon fejlődött és felszaporított embriogén kalluszt használtuk fel a transzformációs kísérletekhez. Az embriogén kallusz tenyészeteket 2 hétre MS/2 táptalajra helyeztük, hogy szomatikus embriófejlődést indukáljunk.

Az előzőleg AB-minimál táptalajra (2. Táblázat) kikent és felszaporított baktériumból szuszpenziót készítettünk ( $10^{8}$ sejt/m1), amelyet pipettával juttattunk rá a szilárd táptalajon indukált 1-2 mm-es embriókból álló tenyészetek felületére, majd két nap kokultiváció következett hormonmentes (MS/2) táptalajon.

2. táblázat: $A B$ minimál táptalaj (Lichtenstein and Draper 1986).

\begin{tabular}{|c|c|}
\hline AB táptalaj összetevöi & koncentráció \\
\hline $\mathrm{K}_{2} \mathrm{HPO}_{4}$ & $3 \mathrm{~g} / \mathrm{l}$ \\
\hline $\mathrm{NaH}_{2} \mathrm{PO}_{4}$ & $1 \mathrm{~g} / \mathrm{l}$ \\
\hline $\mathrm{NH}_{4} \mathrm{Cl}$ & $1 \mathrm{~g} / \mathrm{l}$ \\
\hline $\mathrm{MgSO}_{4} \cdot 7 \mathrm{H}_{2} \mathrm{O}$ & $0,3 \mathrm{~g} / \mathrm{l}$ \\
\hline $\mathrm{KCl}$ & $0,15 \mathrm{~g} / \mathrm{l}$ \\
\hline $\mathrm{FeEDTA}$ & $70 \mathrm{mg} / \mathrm{l}$ \\
\hline $\mathrm{MS}$ Vitamin & $1 \mathrm{ml} / \mathrm{l}$ \\
\hline
\end{tabular}

Kiegészítésként még 0,2-0,5\% szénforrás és agar (1,2\%) szükséges (pH 7). 


\subsubsection{Az Agrobacterium elölése}

A baktérium elölésére a kokultiváció után 1-2 mm-es embriók esetén megfelelő módszer a 300 mg/l carbenicillint és 300 mg/l claforánt (cefotaxim) tartalmazó szilárd táptalajra történő passzálás és fenntartás (Oláh et al. 2003b). Kísérleteink során szelekciós ágensként $20 \mathrm{mg} / \mathrm{l}$ kanamicint használtunk. Antioxidánsnak $4 \mathrm{~g} / \mathrm{l}$ vízben oldhatatlan polyvinylpyrrolidont (Polyclar AT) és $0,1 \mathrm{~g} / 1$ dithioerythritolt (DTE) használtunk (Oláh et al. 2003b), hogy megfelelő védelmet nyújtsanak a transzformált sejtek számára, a szelekció miatt nagy számban elpusztult sejtek által a táptalajba juttatott anyagokkal szemben. Az így kiegészített MS/2 táptalajt MS/2Km jelöléssel láttuk el.

\subsubsection{Növényregeneráció szelekciós táptalajon}

A tenyészetek havonkénti passzálása során a torpedó és korai szikleveles stádiumú embriókat folyamatosan leválasztottuk és Petri-csészében továbbra is MS/2Km táptalajon fényre helyeztuik $\left(24^{\circ} \mathrm{C}, 16\right.$ óra megvilágítás).

A fényen a folyamatos passzálás során a szelekciós nyomás mellett levél- és gyökérkezdeményekkel rendelkező embriókat egyenként $30 \mathrm{ml}$, antioxidánsokat már nem tartalmazó MS/2Km szilárd táptalajjal töltött tenyészedényekbe helyeztük át. A regenerálódott növényekből a havonta történő átrakás és felszaporítás során a hajtáscsúcsot és az alatta található két-rügyes hajtásrészt helyeztük friss táptalajra. Egy évvel a transzformációs kísérletek megkezdése után fokozatosan megvontuk az antibiotikumokat és a szelekciós ágenst a táptalajból. A jól meggyökeresedett egyedeket kondicionálás után üvegházban neveljük tovább (lásd 4.2.6. fejezet).

\subsubsection{A szőlőtranszformáció az MsFerr, iaaM és virE1 gének felhasználásával}

Hasznos génkonstrukciók felhasználásával genetikai transzformációs kísérleteteket végeztünk a 'Richter 110' fajtán. Az oxidatív stressztürő képesség növelésére irányuló kísérleteinkben az EHA105(pRok2Ferr) és EHA105(pRok2FerrFLAG); az Agrobacterium rezisztens növények előállítását célzó kísérleteinkben az EHA101(pTd93virE1), EHA101(pJP17) és EHA101(pJP17-S4) vektorkonstrukciókat használtuk fel. A pRok2Ferr és pRok2FerrFLAG konstrukciók lehetővé teszik a lucerna ferritin gén expresszióját a szőlő kloroplasztiszokban ill. citoplazmában, a megnövekedett ferritin szint pedig hozzájárulhat a szabad vasionok mennyiségének csökkentésével a Fenton-reakció

limitálásához és ezen keresztül az oxidatív stresszel szemben ellenállóbb vonalak 
kialakításához (lásd 3.6 fejezet). A pTd93virE1 konstrukció segítségével Agrobacterium VirE1 fehérjéket termelhetünk a növényi sejtekben. Mivel az Agrobacterium fertőzés során a T-DNS komplex és a VirE2 fehérjék elkülönülten jutnak be a növényi sejtekbe, így a VirE2 fehérjék gátlásával (VirE1 és VirE2 komplex képződés) valószínűleg a szőlő agrobaktériumos vesszőgolyvával szemben ellenállóbb vonalak alakíthatóak ki (lásd még 3.7. fejezet). A géncsendesítés mechanizmusának indukálásához két különböző génkonstrukciót használtunk fel. A pJP17 konstrukció tartalmazza az egymás után épített (A348) iaaM és ipt géneket egymással szemben elhelyezkedő, szensz és antiszensz RNS átírását biztosító promóter közé helyezve; a pJP17-S4 konstrukció az A. vitis S4 iaaM szekvenciát is tartalmazza, amelyben az új szekvencia beillesztése a SalI és BamHI fragment helyére történt (lásd még 3.7. fejezet).

\subsubsection{A transzformációs kísérletek optimalizálása}

Kísérleteink során többféle módszert is kipróbáltunk a növényregeneráció nehézségeinek leküzdése érdekében. Az abnormális fejlődést mutató embriók (9. ábra) pusztuló gyökérnyaki részének eltávolításával megpróbáltuk a normális gyökérfejlödést indukálni, amely a későbbiekben kiválthatja a normális hajtásfejlödést; valamint (1.) antibiotikummentes MS/2 illetve (2.) citokinin tartalmú (0,22 mg/l BA) MS/2Km táptalajra helyeztuik a korábban $\mathrm{MS} / 2 \mathrm{Km}$ szelekciós táptalajon tartott rendellenes fejlődésü embriókat.

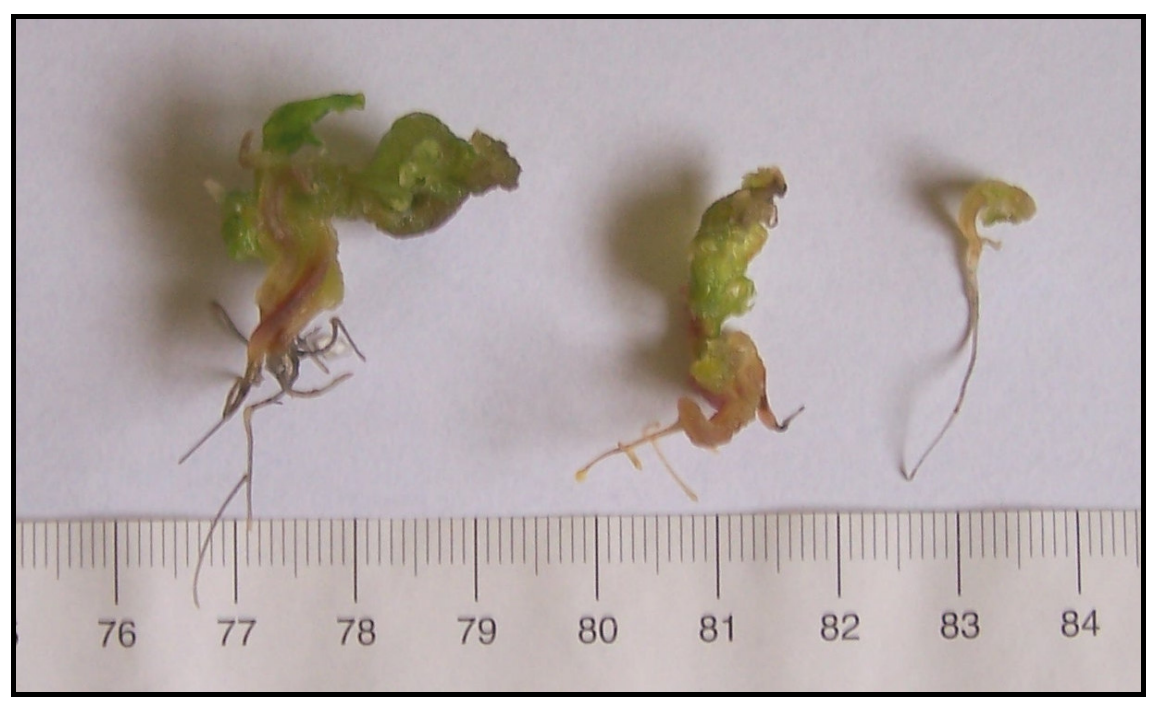

9. ábra: EHA105(pRok2Ferr) vektorral transzformált rendellenes fejlődésü 'Richter 110'embriók. 


\subsubsection{Akklimatizációs kísérletek}

A kísérletekhez az in vitro körülmények között nevelt portok eredetü 'Richter 110' szőlőnövényeket használtuk. A kétrügyes mikrodugványokat hormonmentes, $10 \mathrm{~g} / \mathrm{l}$ szacharózt, 70 mg/l Fe-EDTA-t, és 7 g/l Oxoid agart tartalmazó MS/2 táptalajon (pH 5,8) felszaporított növényekről, olló és csipesz segítségével szedtük steril fülke alatt.

Munkánk során a különböző nedvesítő-, és gyökereztető közegek hatását, valamint a tenyészedények eltérő zárásának (levegőzöttségének) következményeit vizsgáltuk a gyökérképződés mennyiségi és minőségi jellemzőire. A kísérletekben felhasznált kétrügyes mikrodugványokat fényszobában, $24^{\circ} \mathrm{C}$-on, 16 órás megvilágítás mellett gyökereztettük. 18-20 nap elteltével a gyökeres növényeket megvizsgáltuk és értékeltük a gyökerek száma és hossza alapján. Minden kísérletet három ismétlésben végeztünk el. A kapott adatokból növényenkénti átlagos gyökérszámot, átlagos gyökérhosszt, valamint összes gyökérhosszt számoltunk.

Az első kísérletben háromféle nedvesítő közeget használtunk: (1.) steril csapvizet, (2.) $1 \mathrm{mM}$ foszforsav oldatot (pH 6,0), valamint (3.) 1-1 mM dikálium-hidrogén-foszfát és salétromsav oldat kombinációját ( $\mathrm{pH}$ 6,0). A kísérlet célja az volt, hogy kiválasszuk a legmegfelelőbb nedvesítő közeget a gyökereztetéshez. A közegekhez nem adtunk szerves komponenseket, hogy csökkentsük befertőződés veszélyét. Az autoklávban sterilizált 270 ml-es tenyészedényekbe (bébiételes üvegek) töltött kb. $50 \mathrm{ml}$ perlitet laminált fülke alatt nedvesítettük. 15 üvegbe steril csapvizet, 15 üvegbe foszforsav oldatot, 15 üvegbe pedig dikálium-hidrogén-foszfát és salétromsav oldat kombinációját töltöttük, úgy, hogy a perlit megszívja magát és még 2-3 mm folyadék legyen az edény alján.

A második kísérletben négyféle gyökereztető közeget alkalmaztunk (10. ábra). 1515 üvegbe perlitet $(50 \mathrm{ml})$, kőzetgyapotot (4x4x4 cm-es, Grodan; www.grodan.com) és előnedvesített tőzegkockát $(3 \times 3 \times 4 \quad \mathrm{~cm}$-es, pit-pot; www.pit-pot.com $)$ helyeztünk, kontrollként pedig 6 g/1 agarral szilárdított csapvizes agart használtunk $(30 \mathrm{ml}$ tenyészedényenként). Autoklávozás után a perlitre, a kőzetgyapotra és a tőzegkockákra az elökísérletek (nedvesítő közeg kiválasztása) eredményei alapján steril csapvizet öntöttünk úgy, hogy jól megszívják magukat, és az edény alján kb. 2-3 mm folyadék álljon. 

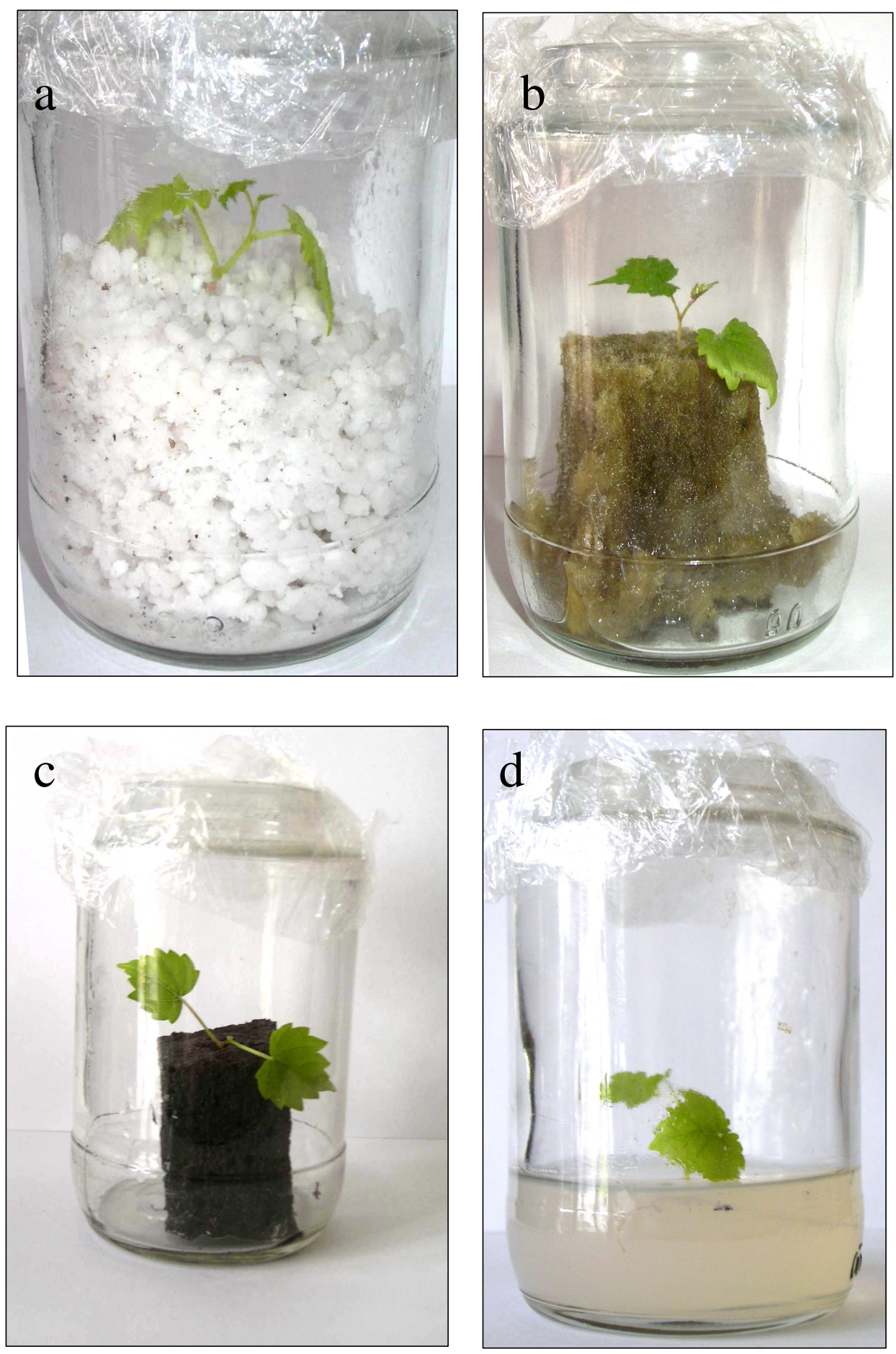

10. ábra: 'Richter 110' mikrodugvány perlitben (a), kőzetgyapotban (b), tőzegkockában (c), csapvizes agarban (d). 
Felmerült, hogy a tenyészedények szellőzése is hatással lehet a növények gyökeresedésére, ezért a harmadik kísérletben két különböző zárási módot alkalmaztunk. A bébiételes üvegekbe $30 \mathrm{ml}$ csapvizes agart töltöttünk, és autoklávban sterilizáltuk. A mikrodugványok ültetését követően 15 üveget 3 réteg háztartási fóliával (Folpack), 15-öt pedig csavaros tetővel fedtünk le, ahol a légcserét a középen fúrt lyukba helyezett szivacsdarab biztosítja.

$\mathrm{Az}$ adatok kiértékelésében igyekeztünk az adatok jellegének megfelelő programot és statisztikai módszert kiválasztani. Így az első kísérlet eredményeinek kiértékeléséhez a ROPSTAT programot használtuk, míg a másik két vizsgálathoz az SPSS 16.0 programot találtuk megfelelőnek. Az eltérő programok használatát az adatok eltérő tulajdonságai indokolták. A nedvesítő közeg, valamint a gyökereztető közeg kiválasztásakor egytényezős varianciaanalízissel elemeztük az eredményeket, 95\%-os megbízhatósági szinten. A zárások vizsgálatánál, mivel csak két kezelést kellett összehasonlítanunk, az adatok értékeléséhez kétmintás t-próbát végeztünk, 95\%-os megbízhatósági szinten.

\subsubsection{A beépített DNS jelenlétének ellenőrzése PCR analízissel}

A DNS izoláláshoz a fényen nevelt növények hajtásairól steril körülmények között begyüjtött leveleket dolgoztuk fel. A levelekből a Qiagen cég DNEasy Plant System Mini Kit DNS-kivonó rendszer segítségével vontuk ki a genomiális DNS-t. A munka során folyékony nitrogént, 95\%-os etanolt, illetve a készlet pufferoldatait (AP1, AP2, AP3, AW, AE) használtuk. Az eljárás lépései:

1. A sejtek feltárása: 0,1-0,2 g levélszövetet folyékony nitrogénben, dörzsmozsárban eldörzsölünk.

2. A mintákat Eppendorf-csövekbe helyezzük, $400 \mu$ l AP2 puffert és $4 \mu 1$ RN-áz enzimet adunk hozzá. A puffer a fehérjéket és poliszacharidokat kicsapja.

3. Az oldatot vortex-szel történő rázatást követően 10 percig $65^{\circ} \mathrm{C}$-on inkubáljuk $(2-3$ átforgatással), majd $130 \mu \mathrm{l}$ AP2 puffert adunk hozzá és 5 percig jégen állni hagyjuk.

4. A lizátumot új Eppendorf-csövekbe, a kithez tartozó QIAshredder szürőre áttöltjük, majd 2 percig centrifugáljuk 13000 fordulat/perc sebességen. Ezzel a nagyobb szennyeződésektől, sejttöredékektől tisztítjuk az oldatot, a szürőn átjutó rész pedig tovább homogenizálódik. 
5. A szürlet újabb Eppendorf-csövekbe kerül (az üledék nélkül), másfélszeres mennyiségü (kb. $675 \mu \mathrm{l}$ ) AP3/E (az AP3 koncentrátuma 95\%-os etanollal hígítva 1:2 arányban) oldatot adunk hozzá; finoman összekeverjük vágotthegyü pipettával.

6. Ebből $650 \mu$ l-t üledékkel együtt Dneasy szürőkre, új Eppendorfba pipettázunk, majd 8000 fordulat/perc-en 1 percig centrifugáljuk, utána a maradék lizátummal ezt megismételjük. A szürő membránján (a szilíciumgélen) magas sókoncentrációnál a DNS-molekulák megtapadnak, a lizátum kicsapott fehérjéi és poliszacharidjai átjutnak rajta.

7. A szürőt Eppendorf-csőbe helyezzük és $500 \mu \mathrm{l} \mathrm{AW}$ puffert adunk hozzá a maradék szennyeződések eltávolítására, majd 1 percig 8000 fordulat/perc-en centrifugáljuk. A szürlet eltávolítása után ismét a szüröre pipettázunk $500 \mu \mathrm{l}$ AW puffert és 2 percig 13000 fordulat/perc-en centrifugáljuk, így a szürő membránja kiszárad.

8. A DNS-szürőt új Eppendorfba helyezzük, $100 \mu 165^{\circ} \mathrm{C}$-os $\mathrm{AE}$ puffert teszünk a membránra és 5 percig szobahőmérsékleten inkubáljuk, majd 1 percig 8000 fordulat/perc-en centrifugáljuk. A DNS leoldást még egyszer megismételjük. A puffer hatására a megváltozott közegben (alacsony sókoncentrációnál) a DNS molekulák leválnak a szilíciumgélről és átjutnak az Eppendorf-csőbe. Az így nyert kb. $200 \mu$ l-nyi oldat kiváló tisztaságban tartalmazza a DNS-t (Qiagen, 2000).

A koncentráció meghatározásához spektrofotométerrel megmértük az oldat fényáteresztését $200 \mathrm{~nm}$ és $300 \mathrm{~nm}$ hullámhossz között. A kapott görbe alapján látható, mennyire tiszta a DNS-oldat (a fehérjék $280 \mathrm{~nm}$ hullámhosszon mutatnak speciális abszorpciót). Ezután megmértük az oldat optikai denzitását $260 \mathrm{~nm}$ hullámhosszon. A kapott érték alapján pontosan kiszámíthattuk, milyen töménységü a DNS-oldat. 1 OD (=optikai denzitás) $50 \mu \mathrm{g} / \mathrm{ml}$ töménységü DNS-oldatnak felel meg (Velich 2001).

A PCR analízis során célunk a bevitt gének jelenlétének kimutatása és a növényi minta Agrobacterium mentességének bizonyítása volt. Az eljárás során a növényi mintából kivont DNS-ből specifikus primerekkel amplifikáltuk az MsFerr, iaaM, virE1, nptII, és virC (Agrobacterium virulencia gén) gének megfelelő szakaszait. A PCR reakció során az nptIIR (5'-AGGCGAGGCGGCTATGACTG-3') és nptIIF (5'ATCGGGAGCGGCGATACCGTA-3') primereket használtuk a szelekciós markergén (kanamicin) jelenlétének ellenőrzésére (Hoffmann et al. 1997), amellyel az nptII 700 bp hosszúságú szakaszát amplifikáltuk. Az Agrobacterium növényben való esetleges jelenlétének ellenőrzésére a VCR (5'-AGCTCAAACCTGCTTC-3') és VCF (5'- 
ATCATTTGTAGCGACT-3') primereket használtuk, amely a T-DNS-en kívül elhelyezkedő 730 bp hosszúságú virC régiót (Sawada et al. 1995) amplifikálja. A vizsgálat negatív eredménye bizonyítja, hogy a növényi DNS mintában nincs vektor DNS szennyeződés.

A lucerna ferritin gén jelenlétének ellenőrzésére az MTA Szegedi Biológiai Központjának Növénybiológiai Intézetében tervezett különböző primer kombinációk közül a FerrFw1 (5'-GTCACGGTGTGTGGCACTTTGA-3') és FerrRev2 (5'AGACAGAGCCAATTCCATGGCA-3') primereket használtuk, amelyekkel a gén 513 bp hosszúságú szakaszát amplifikáltuk (Oláh 2005). Az iaaM gén jelenlétének ellenőrzésére az (5'-GAACCAAGCGGTTGATAACAGCC-3') és (5'CTGCGACTCATAGTCCAGGAATAC-3') primereket használtuk, amelyekkel a gén 150 bp hosszúságú szakaszát amplifikáltuk (Viss et al. 2003) a pJP17 és pJP17-S4 konstrukciókkal transzformált növények mintáiban. A virEl gén jelenlétét pedig az (5'CCATCATCAAGCCGCA-3') és (5'-CTCCTTCTGACCAGCAAGA-3') primerekkel ellenőriztük (Szegedi et al. 2001).

A PCR során a $25 \mu \mathrm{l}$ reakcióelegy 1x Taq puffert, 1,5 mM $\mathrm{MgCl}_{2}$-ot, 5\% DMSO-t, $200 \mu \mathrm{M}$-t minden dNTP-böl, $0,5 \mu \mathrm{M}$-t a két primerből, $2 \mu$ templát DNS-t $(50 \mu \mathrm{g} / \mathrm{ml})$ valamint 1,25 egység Taq polimerázt tartalmazott. A reakciókat $94^{\circ} \mathrm{C}$-on indítottuk (1 perc), majd ezt követően 30 ciklusban $92^{\circ} \mathrm{C}$-on denaturáltuk a DNS-t ( 1 perc), $54^{\circ} \mathrm{C}$-on történt a primerek bekötődése (1 perc) és $72^{\circ} \mathrm{C}$-on $(1,5$ perc) a lánchosszabítás. A reakció lezárása $72^{\circ} \mathrm{C}$-on történt ( 3 perc). A fent leírtaktól eltérően a lucerna ferritin primerek bekötődése $52^{\circ} \mathrm{C}$-on történt. $\mathrm{Az}$ iaaM gén jelenlétének ellenőrzésére használt primerek használatakor a reakciót $94^{\circ} \mathrm{C}$-on indítottuk ( 2 perc), majd ezt követöen 35 cikluson keresztül a denaturáció $94^{\circ} \mathrm{C}$-on 1 percig, a bekötődés $50^{\circ} \mathrm{C}$-on fél percig, a lánchosszabbítás $72^{\circ} \mathrm{C}$-on 1 percig, a reakció lezárása pedig $72^{\circ} \mathrm{C}$-on 5 percig tartott. $\mathrm{Az}$ amplifikációhoz az MJ Research PTC 200 típusú PCR-készülékét használtuk. A minták futtatása 1,5\%-os agaróz gélen történt, majd az amplifikált DNS-t ethidium bromiddal tettük láthatóvá.

\subsubsection{A transzformánsok oxidatív stressztürö képességének vizsgálata}

A klorofillfluoreszcencia-indukciós mérés megbízhatóan alkalmazható vizsgálati módszer az abiotikus stressz és a fotoinhibíció kimutatására. A klorofillfluoreszcencia vizsgálatának alapelve viszonylag egyszerü. A klorofill molekulák által elnyelt fény sorsa 
háromféle lehet: felhasználódhat fotokémiai energiaként, fölösleges energiaként kibocsátható hő formájában, vagy fény formában visszasugárzódhat. Ez a három folyamat versenyez egymással, bármelyik teljesítményének emelkedése a másik kettő teljesítményének csökkenésével jár. Ezért a klorofillfluoreszcencia vizsgálatával információkhoz jutunk a fotoszintézis teljesítményéről és a kibocsátott hő mennyiségéről is. A klorofillfluoreszcencia-méréseket pulzus amplitúdó-modulált fluoriméter, Imaging PAM (Heinz Walz GmbH, Effeltrich, Germany) segítségével végeztük a Schreiber és munkatársai (1986) által leírt protokol szerint. A mérés a mérőfej bekapcsolásával kezdődik, amivel meghatározzuk a minimális fluoreszcencia szintet $\left(\mathrm{F}_{0}\right)$. Utána egy telítő villanófényt használunk, ami lehetővé teszi a maximális fluoreszcencia $\left(\mathrm{F}_{\mathrm{m}}\right)$ mérését. $\mathrm{F}_{\mathrm{m}}$ és $\mathrm{F}_{0}$ különbsége adja az ún. változó fluoreszcenciát $\left(\mathrm{F}_{\mathrm{v}}\right)$, ami a II. fotokémiai rendszer (PSII) fényenergia befogadás hatásfokával arányos. A PSII potenciális hatékonysága jól jellemezhető az $F_{v} / F_{m}$ aránnyal, amely az $F_{v} / F_{m}=\left(F_{m}-F_{o}\right) / F_{m}$ összefüggés alapján határozható meg. Optimális esetben ez az érték 0,72-0,85 közötti tartományba esik, míg a különböző stresszhatásoknak kitett növények esetében ennél kisebb (Bolhár-Nordenkampf and Lechner 1988).

A transzformánsok oxidatív stressztürő képességének vizsgálatát a Magyar Tudományos Akadémia Szegedi Biológiai Központjának Növénybiológiai Intézetével és a Budapesti Corvinus Egyetem Szőlészeti és Borászati Kutató Intézetével (Kecskemét) együttmüködésben, két különböző kísérletben végeztük el. A paraquat hatására fényen oxigén szabadgyökök képződnek a kloroplasztiszokban, ezért első lépésben a transzformánsok oxidatív stressztürő képességének vizsgálatához a paraquat-diklorid (1,1dimetil-4,4-bipiridilium-diklorid) hatóanyagú Gramoxone nevü gyomirtó szert használtuk. A por alakban rendelkezésünkre álló gyomirtó szerből 5 különböző koncentrációjú $(0,5$ $\mu \mathrm{M}, 1 \mu \mathrm{M}, 2 \mu \mathrm{M}, 3 \mu \mathrm{M}, 4 \mu \mathrm{M})$ oldatot használtunk a vizsgálatok során. Kontrollként pedig csapvízben úsztatott leveleket használtunk. Az üvegházban nevelt növények közül 6 db független pRok2Ferr transzformáns és 1 db nem-transzformált kontroll 'Richter 110' növényt választottunk ki. Minden növényröl leválasztottunk 3-3 db levelet, amit három órán keresztül sötétben úsztattunk az oldatban, a levelek színével felfelé. A 3 órás sötét periódust azért alkalmaztuk, hogy biztosítsuk a herbicid ozmotikus felvételét. Ezután a mintákat 1 órán keresztül $35 \mu \mathrm{mol}^{-2} \mathrm{~s}^{-1}$ fotoszintetikusan aktív fénnyel világítottuk meg. Fényen a paraquat a fotoszintetikus elektrontranszportláncból származó elektronok felhasználásával szuperoxidgyököket képez, ami a növények oxidatív károsodásához vezet (Babbs et al. 1989) és a fotoszintetikus teljesítmény csökkenését eredményezi. A 
fluoreszcenciaindukció mérése során a 20 percig sötétadaptált levélmintákat $8000 \mu$ mol $\mathrm{m}^{-2} \mathrm{~s}^{-1}$ fényintenzitású gerjesztő fénnyel világítottuk meg. A kísérletet három ismétlésben végeztük el, majd a kapott $\mathrm{F}_{\mathrm{v}} / \mathrm{F}_{\mathrm{m}}$ értékeket átlagoltuk. A szőlötermesztési gyakorlatban alanyként használt 'Richter 110' fajta esetében a növények gyökérzetét érö stresszhatásokra adott válasz fontos információkkal szolgálhat számunkra, ezért a második kísérletben az üvegházban nevelt 6 db pRok2Ferr transzformáns és 1 db kontroll 'Richter 110 ' növényeket $50 \mathrm{mM} \mathrm{NaHCO}_{3}$ oldattal árasztottuk el, hogy szárazság-, és sóstresszt indukáljunk. A kezelés hatását 15 nap elteltével vizuálisan értékeltük. Annak ellenére, hogy a kloroplasztiszban lokalizálódó lucerna ferritin fehérje az alanyfajták esetében nem bír gyakorlati jelentőséggel, számunkra fontos információkkal szolgálhat. A pRok2FerrFLAG transzformáns növényeket fejlödési rendellenességük miatt nem tudtuk bevonni a kísérletekbe (lásd 5.6. fejezet).

\subsubsection{Agrobacterium rezisztencia vizsgálatok}

Az EHA101(pJP17) vektorral transzformált akklimatizált és üvegházba kiültetett 'Richter 110' növények ellenállóságát az A. tumefaciens A348 és C58, valamint az A. vitis Tm4, AT1 és S4 törzsekkel szemben teszteltük. Az EHA101(pTd93virE1) vektorral transzformált 'Richter 110' növényeket a fejlődési rendellenességükből eredő felszaporítási és akklimatizációs nehézségek miatt kizárólag A. vitis Tm4 törzzsel fertőztük, valamint a fertőzések nagy részét in vitro körülmények között, a fényszobában fenntartott transzgénikus vonalakon végeztük el. A kísérletekben pozitív kontrollként nemtranszformált akklimatizált, illetve in vitro körülmények között nevelt 'Richter 110' növényeket használtunk. A fertőzéshez a különböző törzsekből steril desztillált víz felhasználásával baktérium szuszpenziót készítettünk (30ml vízben 3 kacsnyi baktérium), majd a növények hajtásain a nóduszok közelében lándzsatű segítségével ejtett sebzésekbe pipettával vittük fel a baktérium szuszpenziót és azt a lándzsatűvel be is dolgoztuk a sebbe. Növényenként három fertőzést végeztünk. A továbbra is üvegházban, illetve in vitro fertőzés esetén a fényszobában tartott növényeken az eredményeket másfél hónap elteltével értékeltük. Az értékelés után a tesztelt növényeket autoklávozással megsemmisítettük.

Kísérleteinkben a tanszéki nemesítésü fajták Agrobacterium ellenállóságát is teszteltuik. Az Agrobacterium fertőzéshez a novemberben begyüjtött vesszőket tavasszal üvegházi körülmények között hajtattuk a Budapesti Corvinus Egyetem Szőlészeti és Borászati Kutató Intézetében (Kecskemét). A tesztelés során az A. tumefaciens C58, az A. 
vitis Tm4, AB3, AT1, és S4 törzsekkel fertőztük a 'Pegazus' (N58), 'Csépi muskotály' (N127), 'Borostyán’ (N200), 'Odysseus', 'Orpheus', 'Taurus', 'Korai bíbor' és 'Pannon frankos' fajtákat. Pozitív kontrollként a fogékony 'Kékfrankos' és 'Szürkebarát', negatív kontrollként pedig a rezisztens 'Kunbarát' fajtát használtuk (Szegedi 1981). 


\section{EREDMÉNYEK}

\subsection{Embriogén kallusz indukálása portokon}

A szőlő embriogén kapacitása erősen genotípus-függő, ezért az embriogén kallusz indukciós kísérleteinkben 12 különböző szőlőfajtát vizsgáltunk. A táptalajra helyezett portokokon 3 hónap inkubációs időt követően 0,25-12\%-os hatékonysággal (3. és 4. táblázat) 11 genotípus esetében kaptunk embriogén kalluszt (11. ábra). Az 'Arany sárfehér' fajtánál nem sikerült embriogén kallusz fejlődést indukálnunk az MSE táptalajon. A 'Korai bíbor', 'Odysseus', 'Orpheus' és 'Pannon frankos' fajtáknál elsőként sikerült embriogén kallusz fejlődést indukálnunk. Az embriogén kallusz indukciós kísérletek eredményeit a táptalajra helyezett portokokon fejlődött embriogén struktúrájú kallusz százalékos értékében adtuk meg [(embriogén kalluszt produkáló portokok száma / összes portokok száma) x 100]. Kísérleteinkben többféle típusú kallusz jelent meg, ezek közül csak a világossárga, keményebb állagú, proembrionális szerkezetet mutató, gömbszerü képletekből felépülő kalluszcsomók bizonyultak később embriogén jellegünek. Kalluszindukció tekintetében az MSE táptalaj bizonyult a legsikeresebbnek, alkalmazásával 9 fajtán kaptunk embriogén kalluszt. Az MST táptalaj 4, a NNE táptalaj 5, az MSE/2 táptalaj pedig csak 1 fajtánál adott pozitív eredményt.

Az embriogén kallusz indukciós kísérletek céljára begyüjtött 'Chardonnay' virágzatok sterilizációja során alkalmazott két különböző eljárás vizsgálatakor arra a következtetésre jutottunk, hogy a $\mathrm{NaOCl}$ oldat helyett ugyanolyan jó eredménnyel használható a klór-mentes $\mathrm{Ca}(\mathrm{OH})_{2}$ oldat is (5. táblázat), melynek létjogosultsága a szőlő klórérzékenységével indokolható. A kísérletben felhasznált négyféle táptalaj közül az MSE és CPE táptalajokon közel azonos hatékonysággal sikerült embriogén kalluszt indukálnunk. Az antioxidánssal és fenolkötő vegyülettel kiegészített MSE táptalaj, valamint az aktív szénnel kiegészített MSE táptalaj negatív hatással volt az embriogén kallusz indukcióra (5. táblázat). 


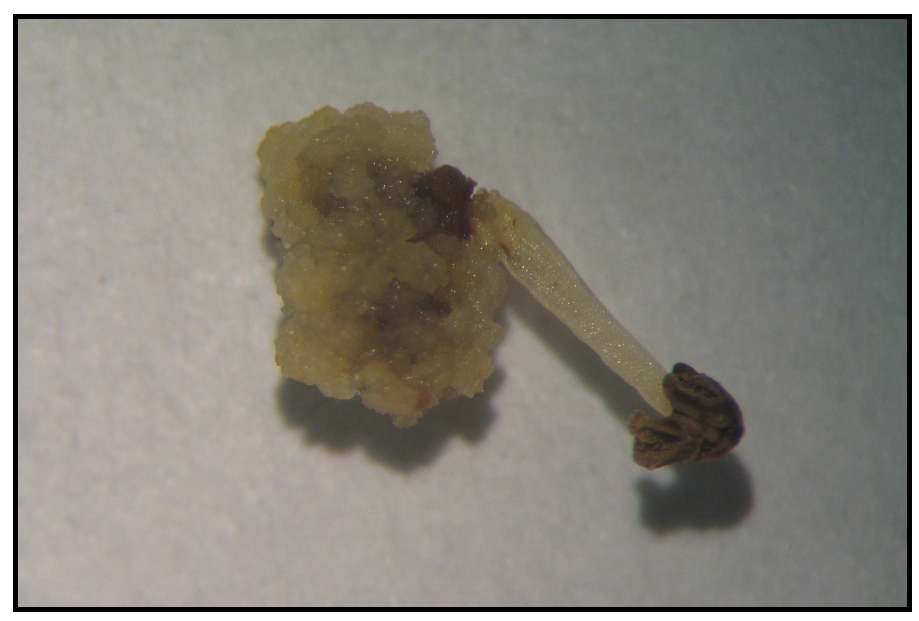

11. ábra: 'Chardonnay’ portokon fejlődött embriogén kallusz.

3. táblázat: Az embriogén kallusz indukciós kísérletek eredményei MSE ill. MST táptalajon.

\begin{tabular}{|l|c|c|c|}
\hline \multirow{2}{*}{ Fajták } & \multicolumn{3}{|c|}{ Az embriogén kallusz indukció eredményei (\%) } \\
\cline { 2 - 4 } & Táptalaj & Átlag & Szórás \\
\hline 'Arany sárfehér' & MSE & - & - \\
\hline 'Cabernet franc' & MSE & 7,5 & 5 \\
\hline 'Odysseus'* & MSE & 1,25 & 1,37 \\
\hline 'Orpheus'* & MSE & 6 & 7,2 \\
\hline 'Richter 110' & MST & 8 & 4,8 \\
\hline 'Taurus' & MSE & 3,33 & 3,81 \\
\hline
\end{tabular}

* Azok a fajták, amelyeknél elsőként sikerült portokon embriogén kalluszt indukálni

4. táblázat: Az embriogén kallusz indukciós kísérletek eredményei (\%) négy különböző táptalajon átlag és szórás értékekkel feltüntetve.

\begin{tabular}{|l|c|c|c|c|}
\hline Fajták & MSE & MSE/2 & NNE & MST \\
\hline 'Chardonnay' & $4,46 \pm 7,08$ & $9,17 \pm 5,84$ & $1,5 \pm 3,64$ & $0,25 \pm 0,79$ \\
\hline 'Kékfrankos' & $7,8 \pm 3,67$ & 0 & $12 \pm 6,02$ & $1,25 \pm 0,7$ \\
\hline 'Korai bíbor'* & $1,25 \pm 1,37$ & 0 & $2 \pm 3,26$ & 0 \\
\hline 'Pannon frankos'* & 0 & 0 & $11,08 \pm 7,81$ & 0 \\
\hline 'Rajnai rizling' & $4,2 \pm 3,75$ & 0 & 2,5 & 0 \\
\hline 'Teleki 5C' & 5 & 0 & 0 & $6,67 \pm 5,2$ \\
\hline
\end{tabular}

* Azok a fajták, amelyeknél elsőként sikerült portokon embriogén kalluszt indukálni 
5. táblázat: Embriogén kallusz indukció eredményei négy különböző táptalajon $\mathrm{NaOCl}$ és $\mathrm{Ca}(\mathrm{OH})_{2}$ oldatban sterilizált ‘Chardonnay’ virágzatokból kipreparált portokokon.

\begin{tabular}{|c|c|c|c|c|}
\hline \multirow{2}{*}{$\begin{array}{l}\text { Sterilizáció módja } \\
\mathrm{NaOCl} \text { oldat }\end{array}$} & \multicolumn{4}{|c|}{ Az embriogén kallusz indukció eredményei (\%) } \\
\hline & MSE & $\mathrm{MSE}+\mathrm{C}$ & MSE+Polyclar AT+DTE & $\mathrm{CPE}$ \\
\hline \begin{tabular}{l|l|l}
1. &
\end{tabular} & 0 & 0 & \begin{tabular}{|c|}
0 \\
\end{tabular} & 5 \\
\hline 2. & 10 & 0 & 0 & 10 \\
\hline 3. & 10 & 0 & 0 & 5 \\
\hline 4. & 5 & 0 & 5 & 10 \\
\hline 5. & 0 & 0 & 0 & 0 \\
\hline 6. & 5 & 0 & 5 & 0 \\
\hline 7. & 0 & 0 & 5 & 5 \\
\hline 8. & 0 & 0 & 5 & 15 \\
\hline 9. & 5 & 0 & 0 & 10 \\
\hline 10. & 0 & 0 & na & 10 \\
\hline Átlag & 3,5 & - & 2,2 & 7 \\
\hline Szórás & 4,11 & - & 2,63 & 4,83 \\
\hline $\mathrm{Ca}(\mathrm{OH})_{2}$ oldat & MSE & $\mathrm{MSE}+\mathrm{C}$ & MSE+Polyclar AT+DTE & $\mathrm{CPE}$ \\
\hline 1. & 5 & 0 & \begin{tabular}{|c|}
0 \\
\end{tabular} & 15 \\
\hline 2. & 15 & 0 & 0 & 5 \\
\hline 3. & 0 & 0 & 0 & 30 \\
\hline 4. & 0 & 0 & 0 & 5 \\
\hline 5. & 10 & 0 & 5 & 5 \\
\hline 6. & 10 & 0 & 0 & 0 \\
\hline 7. & 15 & 0 & 5 & 25 \\
\hline 8. & na & 0 & 0 & 10 \\
\hline 9. & na & 0 & 0 & 0 \\
\hline 10. & na & 0 & 5 & 20 \\
\hline Átlag & 11,5 & - & 1,5 & 11,5 \\
\hline Szórás & 6,36 & - & 2,29 & 10,55 \\
\hline
\end{tabular}

na: Nincs adat a tenyészetek befertőződése miatt

\subsection{Embriogén kallusz felszaporítása}

A transzformációs és regenerációs kísérletekhez szükséges kiindulási anyag mennyiségének folyamatos biztosításához a portokokon fejlődött kalluszt első lépésben fel kell szaporítanunk. Ezt havonként friss táptalajra történő átrakással érhetjük el, azonban a hosszú ideig fenntartott kalluszban különböző minőségi változások következhetnek be. Mivel az embriogén kallusz indukció a különböző környezeti tényezőknek köszönhetően nem minden évben müködik azonos hatékonysággal, ezért fontos a már meglévő kallusz tenyészeteinket a lehető legjobb minőségben megőrizni és fenntartani, hogy az egy-egy 
kieső év ellenére is folyamatosan álljon rendelkezésünkre megfelelő struktúrájú embriogén anyag a már meglévő tenyészetekből.

Kísérleteinkben az embriogén kallusz felszaporítását két különböző táptalajon végeztük a 'Richter 110' alanyfajtánál, azonban a kallusz tömeg értékekben nem kaptunk statisztikailag értékelhető különbséget. Az MSE és CPE táptalajokon az átlagokat tekintve az 1. és 2. hónap után is nagyon hasonló értékeket kaptunk (6. táblázat), azonban a két különböző táptalajon minőségbeli eltéréseket figyeltünk meg. A CPE táptalajon fenntartott kallusz morfológiailag eltért az MSE táptalajon fenntartott kallusztól, ami valószínűsíthetően az embriogén jellegü struktúrák kiszelektálódásából és felszaporodásából valamint a nem-embriogén struktúrák nekrózisából adódott. Ezért a CPE táptalajt alkalmasabbnak találtuk az embriogén kapacitás megőrzésére a szignifikáns különbség hiányának ellenére is.

6. táblázat: Az MSE és CPE táptalajon felszaporított 'Richter 110' embriogén kallusz tömegében mért különbségek az 1. és 2. hónap után.

\begin{tabular}{|c|c|c|c|c|c|c|c|c|}
\hline \multirow[b]{2}{*}{ Táptalaj } & \multirow[b]{2}{*}{ Idő (hónap) } & \multicolumn{5}{|c|}{ Ismétlések } & \multirow[b]{2}{*}{ Átlag } & \multirow[b]{2}{*}{ Szórás } \\
\hline & & 1. & 2. & 3. & 4. & 5. & & \\
\hline MSE & 1. & $1,8 \mathrm{~g}$ & $1,7 \mathrm{~g}$ & $2,4 \mathrm{~g}$ & $3,2 \mathrm{~g}$ & $3,3 \mathrm{~g}$ & $2,48 \mathrm{~g}$ & 0,75 \\
\hline CPE & 1. & $2,2 \mathrm{~g}$ & $2,2 \mathrm{~g}$ & $2,2 \mathrm{~g}$ & $\mathrm{nt}$ & $2,3 \mathrm{~g}$ & $2,23 \mathrm{~g}$ & 0,05 \\
\hline MSE & 2. & $2,8 \mathrm{~g}$ & $2,8 \mathrm{~g}$ & $3,7 \mathrm{~g}$ & $5,1 \mathrm{~g}$ & $4,7 \mathrm{~g}$ & $3,82 \mathrm{~g}$ & 1,06 \\
\hline $\mathrm{CPE}$ & 2. & $3,1 \mathrm{~g}$ & $3,0 \mathrm{~g}$ & $3,3 \mathrm{~g}$ & $\mathrm{nt}$ & $3,3 \mathrm{~g}$ & $3,18 \mathrm{~g}$ & 0,15 \\
\hline
\end{tabular}

nt: nem tesztelt 


\subsection{Növényregeneráció embriogén kalluszból}

Az embriogén tenyészetek embriogén kapacitását hormonmentes szilárd MS/2 táptalajon növényregenerációval bizonyítottuk (12. ábra). A sikeres növényregeneráció limitáló tényezői közül leggyakrabban a hajtásdifferenciálódás elmaradásával találkoztunk, ez pedig jelentősen lecsökkentette a regeneráció hatékonyságát.

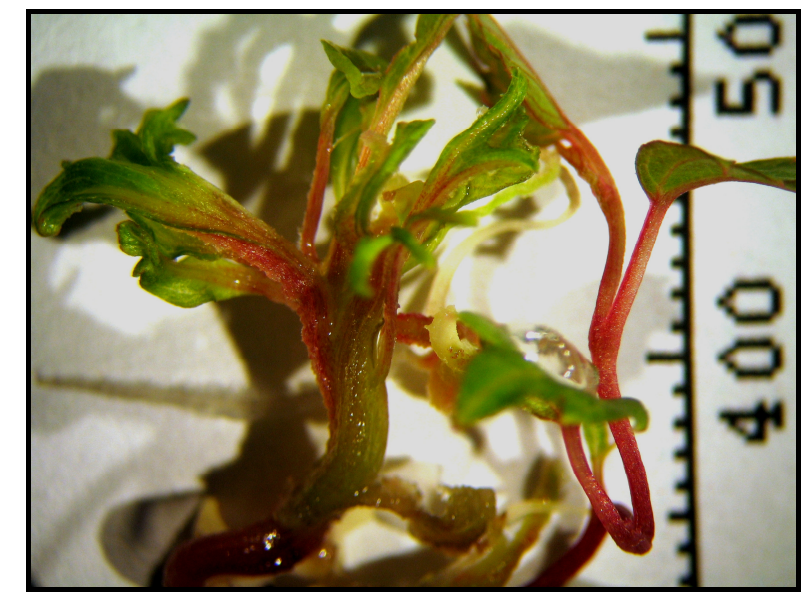

12. ábra: A 'Richter 110’ fajta regenerációja embriogén kalluszból hormonmentes MS/2 táptalajon.

\subsubsection{A növényregeneráció hatékonyságának optimalizálása}

A növényregeneráció nehézségekbe ütközhet, ha a regenerációs kísérletekben felhasznált embriók nincsenek azonos fejlettségi állapotban, ezen kívül a sokáig fenntartott embriogén kultúrák regenerációs képessége csökken (Martinelli et al. 2001a). A 'Richter 110', 'Teleki 5C' és 'Chardonnay' fajták esetében a folyékony MSNOA táptalajt használtunk a számunkra legoptimálisabb állapotú, kis vakuolumokkal rendelkező, gyorsan osztódó sejtek felszaporítására. A folyékony MSNOA táptalaban homogenizált embriogén tenyészetek a két hetes sötétben történő rázatást követően hormonmentes MS/2 táptalajon gyorsabban regenerálódtak, mint a szilárd MSE táptalajról származó, ugyancsak hormonmentes MS/2 táptalajra helyezett embriogén tenyészetek. A folyékony táptalajban történt kezelés után - hormonmentes MS/2 táptalajon - 1 hónap elteltével tömeges hajtás és gyökér differenciálódást (13. ábra) tapasztaltunk mindhárom fajtánál. A szilárd MSE táptalajról származó kultúrákon azonban ekkor még csak a szomatikus embriogenezis kezdeti stádiumait lehetett megfigyelni. Eredményeink alátámasztják a folyékony táptalaj 
használatának jótékony hatását a szomatikus embriogenezisre, illetve a növényregenerációra.
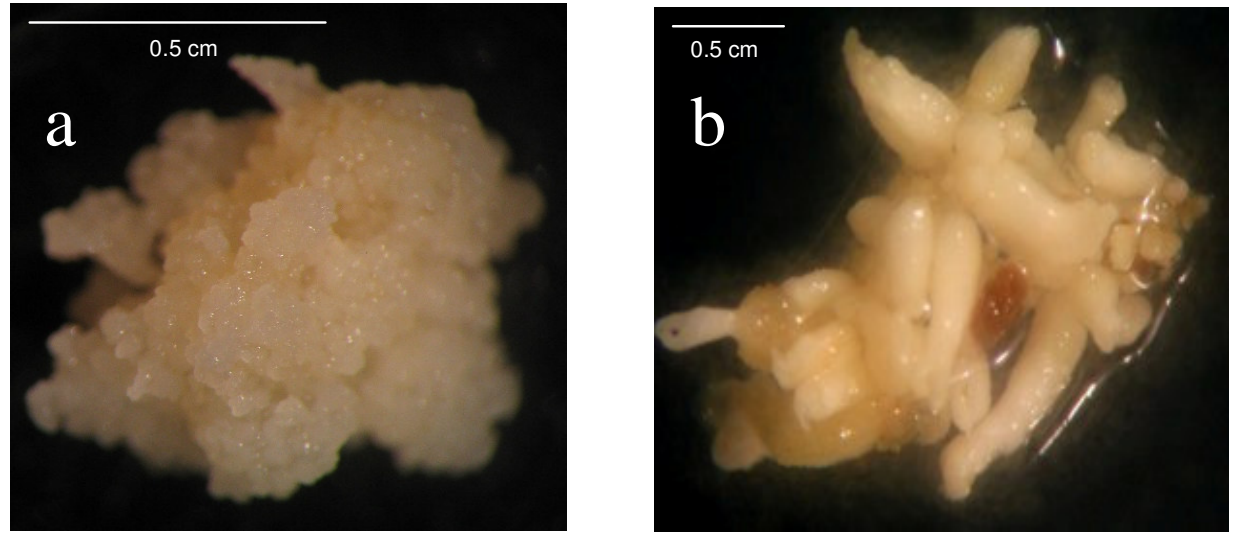

13. ábra: szilárd MSE táptalajon (a, nagyítás: 6,5x) és MSNOA folyékony táptalajban (b, nagyítás: 2,5x) felszaporított 'Richter 110' embriogén kallusz közötti regenerációbeli különbségek egy hónappal az MS/2 táptalajra helyezés után.

A CP és MS/2 táptalajt összehasonlító növényregenerációs kísérleteinkben a 'Chardonnay' fajta esetében a regenerációs idő hosszát illetően eltérést tapasztaltunk. A CP táptalajon 2 hónap elteltével hajtással és gyökérrel rendelkező kis szőlő növényeket kaptunk, az MS/2 táptalajon ugyanennyi idő múlva még csak csírázó embriókat figyelhettünk meg (14. ábra). 

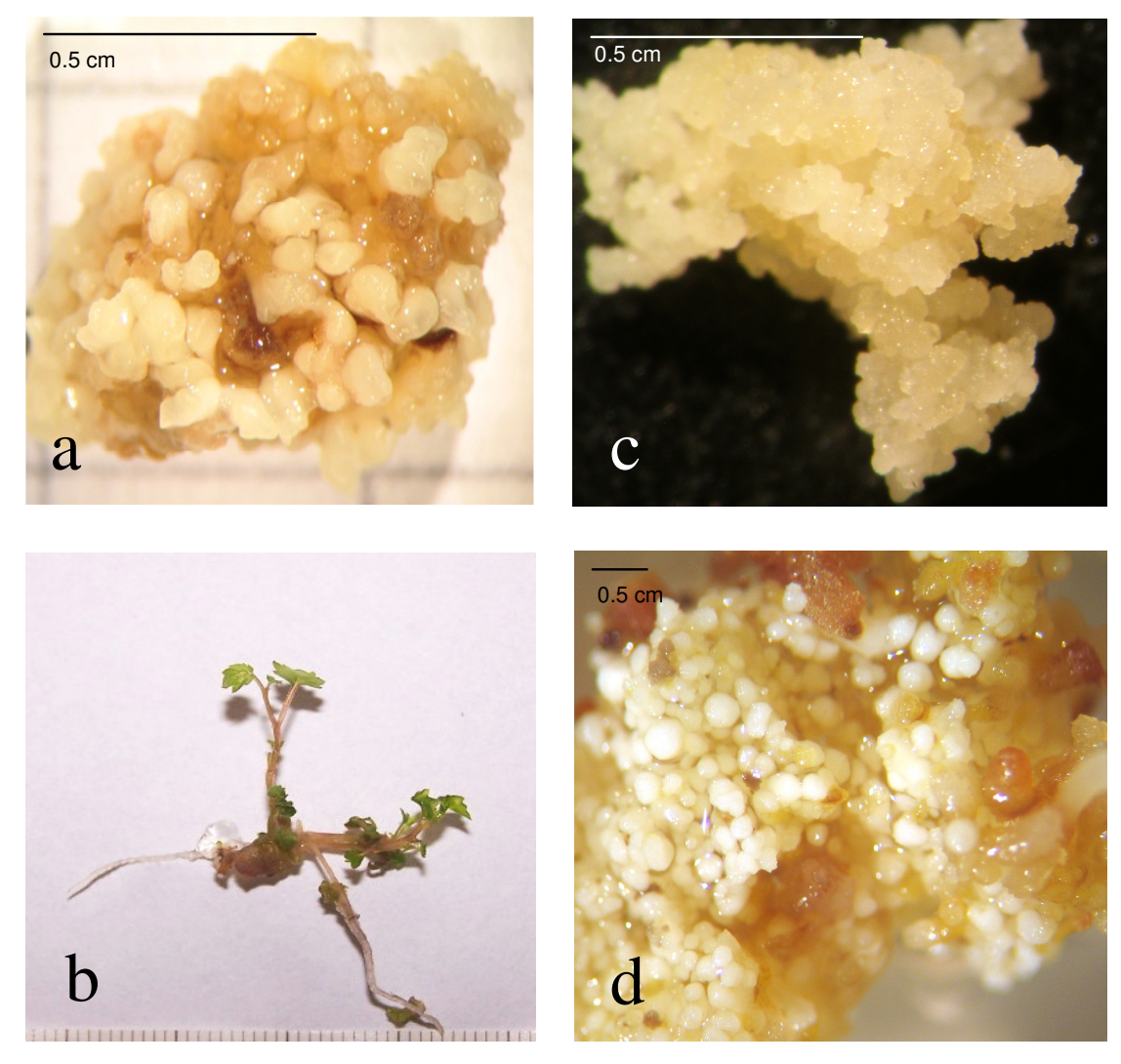

14. ábra: A 'Chardonnay’ embriogén kallusz regenerációjának összehasonlítása $\mathrm{CP}(\mathrm{a}, \mathrm{b}$, nagyítás: 6x) és MS/2 (c, d, nagyítás: 1,5 x) táptalajon.

a, c egy hónappal a táptalajra helyezés után,

b, d két hónappal a táptalajra helyezés után.

\subsection{Direkt organogenezis}

Kísérleteket végeztünk a rügyalap sejtjeinek organogenetikus potenciáljának felmérésére, vizsgáltuk milyen mértékben képes a 'Richter 110' alanyfajta a rügy kivakítása illetve szem eltávolítása után hajtást képezni a megmaradt szövetekből. A kísérletekben a 0,25 mg/l thidiazuron (TDZ) használata bizonyult sikeresnek (15. ábra), azonban a regeneráció hatékonysága $1 \%$ alatt maradt. 


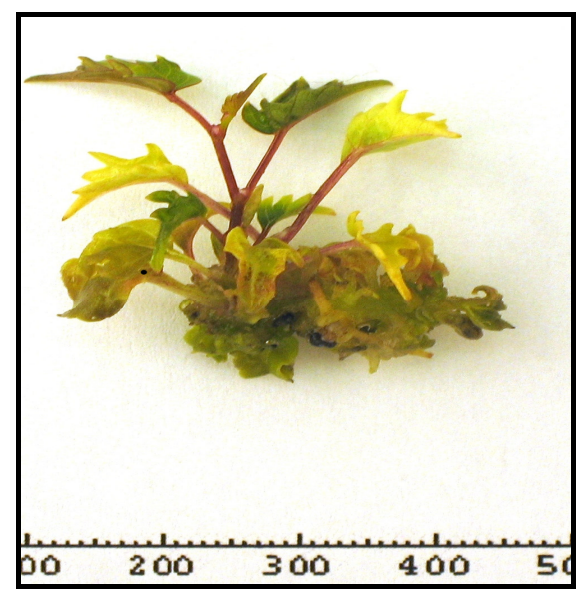

15. ábra: A 'Richter 110' rügyalap sejtjeinek organogenezise.

\subsection{Szőlőtranszformáció}

A szőlőtranszformációs kísérleteket az A. tumefaciens EHA105(pRok2Ferr), EHA105(pRok2FerrFLAG), EHA105(pRok2), EHA101(pTd93virE1), EHA101(pJP17) és EHA101(pJP17-S4) transzformációs vektorokkal végeztük el. Transzformálandó növényanyagként a $V$. rupestris $x \quad V$. berlandieri eredetü 'Richter 110 ' alanyfajtából előállított embriogén kalluszt használtuk. A hormonmentes táptalajon fejlődött 1-2 mm nagyságú szomatikus embriókat (16. ábra) Agrobacterium szuszpenzióval kezeltük, majd a kokultiváció után a növényanyagot az $\mathrm{MS} / 2 \mathrm{Km}$ jelöléssel ellátott szelekciós táptalajra helyeztük át.

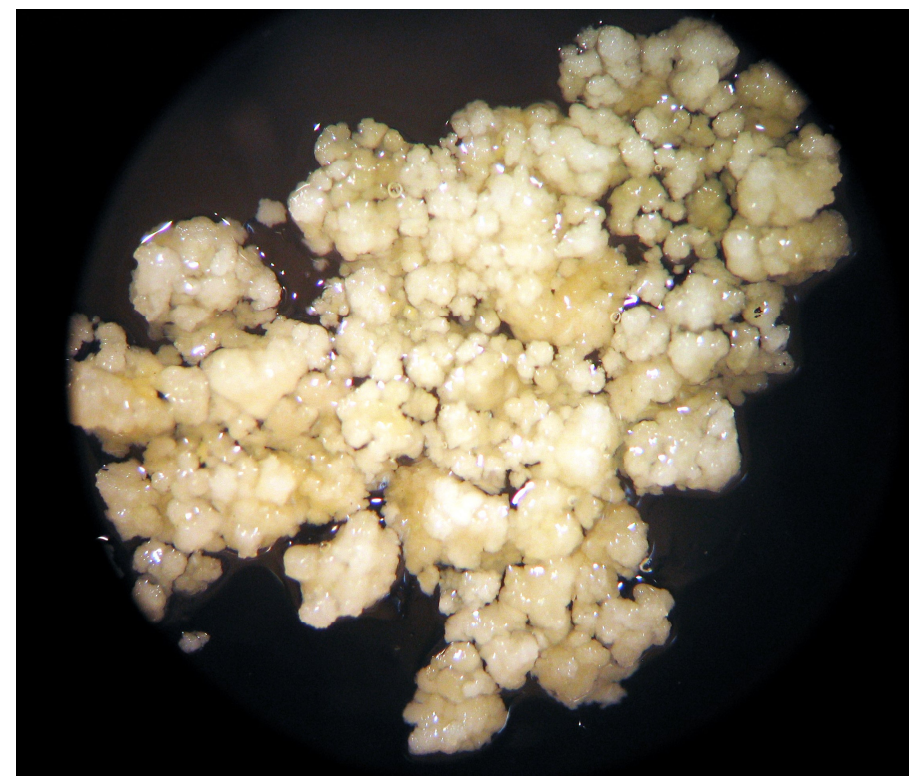

16. ábra: Szomatikus embriók indukálása MS/2 táptalajon. 
A szelekciót kb. 1,5 évig végeztük havonta friss szelekciós táptalajra történő passzálással, miközben a gyökérrel és levélkezdeménnyel rendelkező embriókat tartalmazó tenyészedényeket folyamatosan fényre helyeztük (17. ábra).

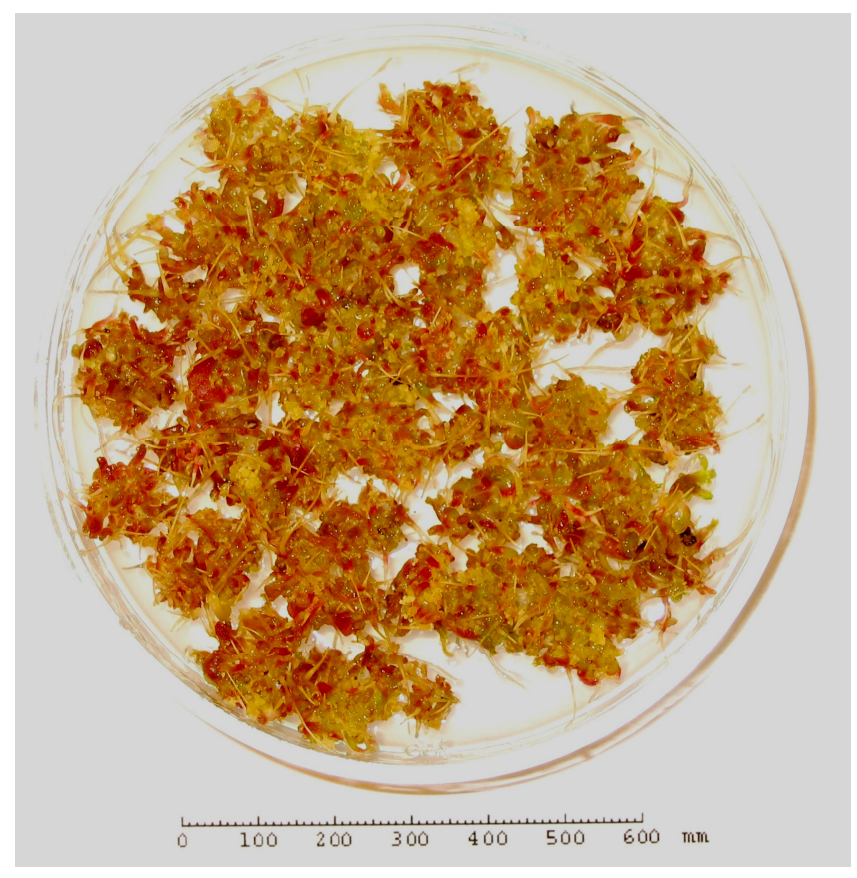

17. ábra: A fejlődő embriók fényre helyezése.

A fényre helyezett embriókat egyedenként az antioxidánsokat már nem tartalmazó MS/2Km táptalajon neveltük tovább. A növényregenerációt addig végeztük, amíg megfelelö számú növényt kaptunk a további vizsgálatokhoz. A transzformáns növények konstrukciónként egy kísérletből származtak. A gyökérrel és hajtással rendelkező egyedek felszaporításra kerültek azáltal, hogy feldaraboltuk őket és nem csak a hajtáscsúcs, hanem az alatta lévő kétrügyes dugvány is friss táptalajra került (18. ábra). Ezt követően a szelekciós ágenst (kanamicin) és az antibiotikumokat (carbenicillin, claforán) fokozatosan megvontuk a táptalajból (az 1. év után). 


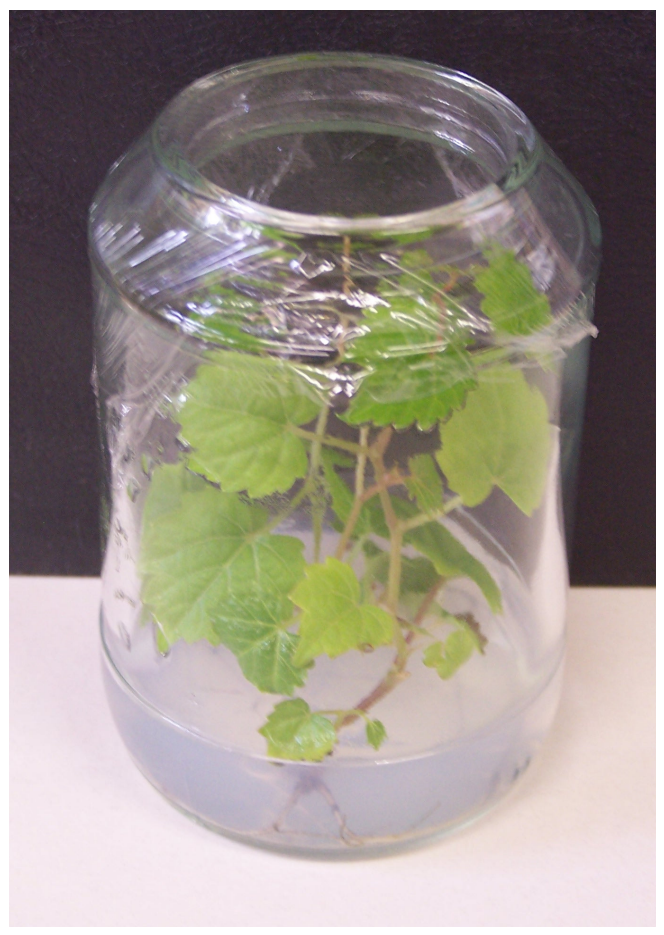

18. ábra: A feltételezett transzformáns ‘Richter 110’ növény felszaporítása.

\subsubsection{A transzformációs kísérletek optimalizálása}

A transzformált embriók sokszor rendellenes fejlődésüek, ez pedig a regenerációs idő kitolódását, illetve rosszabb esetben a regeneráció teljes hiányát eredményezi. Az EHA105(pRok2Ferr) vektorral transzformált embriogén anyag regenerációja során nagy mennyiségben (60\%) figyeltünk meg abnormális embrió-fejlődést. A probléma leginkább a sziklevél-, és gyökérkezdeménnyel rendelkező szomatikus embrioidok fényre helyezését követően jelentkezett, melynek köszönhetően két év folyamatos szelekció után sem tapasztaltunk megfelelő hatékonyságú növényregenerációt. Az MS/2Km szelekciós táptalajon tartott, abnormális fejlődést mutató, EHA105(pRok2MsFerr) vektorral transzformált 'Richter 110' embriók pusztuló gyökérnyaki részének eltávolítása, vagy a szelekciós ágens megvonása nem növelte a regenerált növények számát, de jelentősen lerövidítette a regeneráció idejét. A $0,22 \mathrm{mg} / \mathrm{l}$ BA használata azonban jelentősen megnövelte az EHA105(pRok2MsFerr) vektorral transzformált 'Richter 110' növények számát (19. ábra), a szelekciós táptalajon két év alatt regenerálódott növények száma 24\%ról $62 \%$-ra változott a hormon használatának köszönhetően további 3 hónap alatt. A kísérlet eredményeit a 7. táblázat tartalmazza. Ezért a további transzformációs kísérletekben, ha a szomatikus embriók fényre helyezését követően fejlődésbeli 
rendelleneségeket tapasztaltunk, a legközelebbi friss táptalajra történő átrakásnál a szelekciós táptalajt 0,22 mg/l BA-nel egészítettük ki. A hormont csak akkor vontuk meg a táptalajból, amikor az embriókból levéllel és gyökérrel rendelkező növények regenerálódtak. A transzformációs kísérletek optimalizálásának köszönhetően mind a hat génkonstrukció esetében sikeresen regeneráltuk és felszaporítottuk a további vizsgálatokhoz szükséges mennyiségü független transzformáns vonalat.

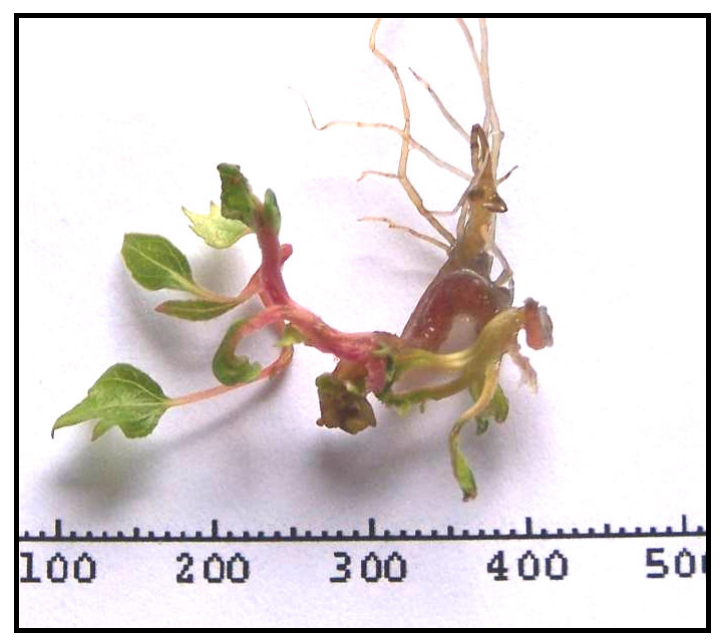

19. ábra: A citokinin tartalmú $\mathrm{MS} / 2 \mathrm{Km}$ táptalajra helyezett EHA105(pRok2MsFerr) vektorral transzformált rendellenes fejlődésü 'Richter 110’ embrió regenerációja.

7. táblázat: $\mathrm{Az}$ MS/2Km és a $0,22 \mathrm{mg} / \mathrm{l} \mathrm{BA}-\mathrm{nel}$ kiegészített MS/2Km táptalaj hatásának összehasonlítása az EHA105(pRok2MsFerr) vektorral transzformált abnormális fejlődést mutató ‘Richter 110’ embrióknál.

\begin{tabular}{|c|c|c|}
\hline Petri-csésze & MS/2Km & MS/2Km+BA \\
\hline 1 & $0 / 38(0)$ & $5 / 26(19,2 \%)$ \\
\hline 2 & $0 / 30(0)$ & $2 / 23(8,7 \%)$ \\
\hline 3 & $3 / 33(9 \%)$ & $9 / 25(36 \%)$ \\
\hline 4 & $0 / 32(0)$ & $2 / 15(13,3 \%)$ \\
\hline 5 & $1 / 17(5,8 \%)$ & $6 / 17(35,3 \%)$ \\
\hline 6 & $0 / 28(0)$ & $7 / 22(31,8 \%)$ \\
\hline Átlag (szórás) & $2,46 \%(3,95)$ & $24,05 \%(11,87)$ \\
\hline
\end{tabular}




\subsection{Az akklimatizációs kísérletek eredményei}

Az EHA105(pRok2Ferr) transzformánsok akklimatizációja során találkoztunk azzal a problémával, hogy a regenerációs táptalajon felnevelt és felszaporított, gyökérrel és hajtással rendelkező növények a kiültetést követően nem fejlödtek tovább, nagy részük elpusztult. Véleményünk szerint a sikertelenség oka a kiültetett növények nem megfelelő minőségü és mennyiségü gyökérzete, ezért kísérleteket végeztünk annak érdekében, hogy a mikroszaporított növények edzését és üvegházba történő kiültetését hatékonyabbá tegyük. Kísérleteink során megpróbáltunk olyan körülményeket kialakítani, amelyben a növények rövid idő alatt megfelelő mennyiségű és jó minőségű (elágazó) gyökérzetet fejlesztenek. A különböző kórokozók és mikroorganizmusok felszaporodásának megakadályozása céljából olyan gyökereztető közeget kerestünk, amely nem tartalmaz szerves komponenseket. Fontos szempont volt, hogy kiültetéskor ne kelljen lemosni a közeget a gyökerekről, ezáltal minimálisra csökkentsük a sérüléseket.

A három ismétlés eredményei alapján 95\%-os valószínüségi szinten nem volt szignifikáns különbség a háromféle nedvesítő közeg/oldat (steril csapvíz, $1 \mathrm{mM}$ foszforsav oldat, 1-1 mM dikálium-hidrogén-foszfát és salétromsav oldat kombinációja) között a gyökerek növényenkénti száma, átlagos hosszúsága és összes hosszúsága szerint. A 'Richter 110' növények tehát a gyökeresedésükhöz nem igényeltek szervetlen sókat, sterilizált csapvízben is megfelelően gyökeresedtek, ezért a további kísérletekhez az egyszerüség kedvéért csapvízzel nedvesítettük a közegeket.

A négyféle gyökereztető közeg (perlit, pit-pot, kőzetgyapot és agar) között a gyökerek számát illetően nem volt szignifikáns különbség a statisztikai számítások alapján. A növényenkénti összes gyökérhossz adatok értékelése során azonban különbségeket tapasztaltunk. A kőzetgyapotban nevelt mikrodugványok szignifikánsan kisebb gyökérméretekkel rendelkeztek, mint amelyek csapvizes agarban vagy perlitben nevekedtek. Ez utóbbi két közeg között nem volt szignifikáns különbség. A tőzegkockában gyökereztetett növények, gyökérméretük alapján, a kőzetgyapotban és a csapvizes agarban illetve a perlitben gyökereztetett növények között helyezkednek el (20. ábra). A növényenkénti átlagos gyökérhossz értékek alapján csupán a kőzetgyapotban gyökereztetett szőlő növények múlták alul szignifikánsan a többi gyökereztető közegben nevelt növényeket (21. ábra). A csapvizes agarban, a perlitben és a tőzegkockában gyökereztetett dugványok átlagos gyökérhossz értékei szignifikánsan nem különböztek 
egymástól. A mért adatokon kívül megfigyeltük még, hogy a perlitben képződött gyökerek elágazóak voltak, míg a másik három közegben a gyökerek nem ágaztak el (22. ábra).

A gyökereztető közegek közül a perlit és a tőzegkocka is megfelelőnek bizonyult az agar kiváltására. A tőzegkockában ugyan rövidebb gyökerek fejlődtek, mint a perlitben, de mivel több gyökér képződött benne, ezért az összes gyökértömeg megközelítőleg ugyanakkora volt mindkét közegben. A perlit elönye, hogy a benne gyökeresített növények elágazó gyökérzetet fejlesztettek, ez nagymértékben növeli életképességüket. A vizes agar várakozásainkkal ellentétben meglepően jól szerepelt a kísérletekben, amit indokolhat, hogy a 'Richter 110’ alanyfajta a gyökérképzésnél kevésbé érzékeny a levegőellátottságra, mint pl. a nemes fajták.

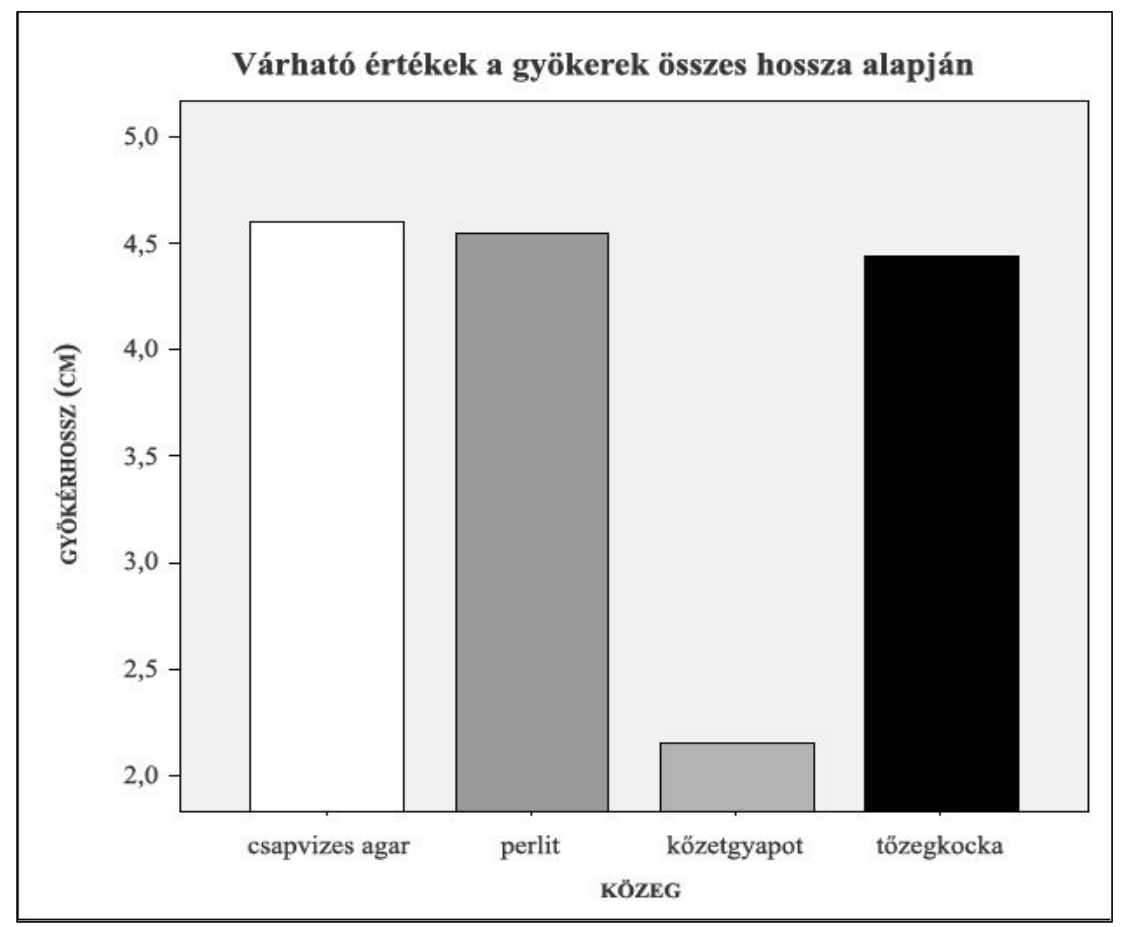

20. ábra: A gyökerek összes hosszúsága csapvizes agarban, perlitben, kőzetgyapotban és tőzegkockában. 


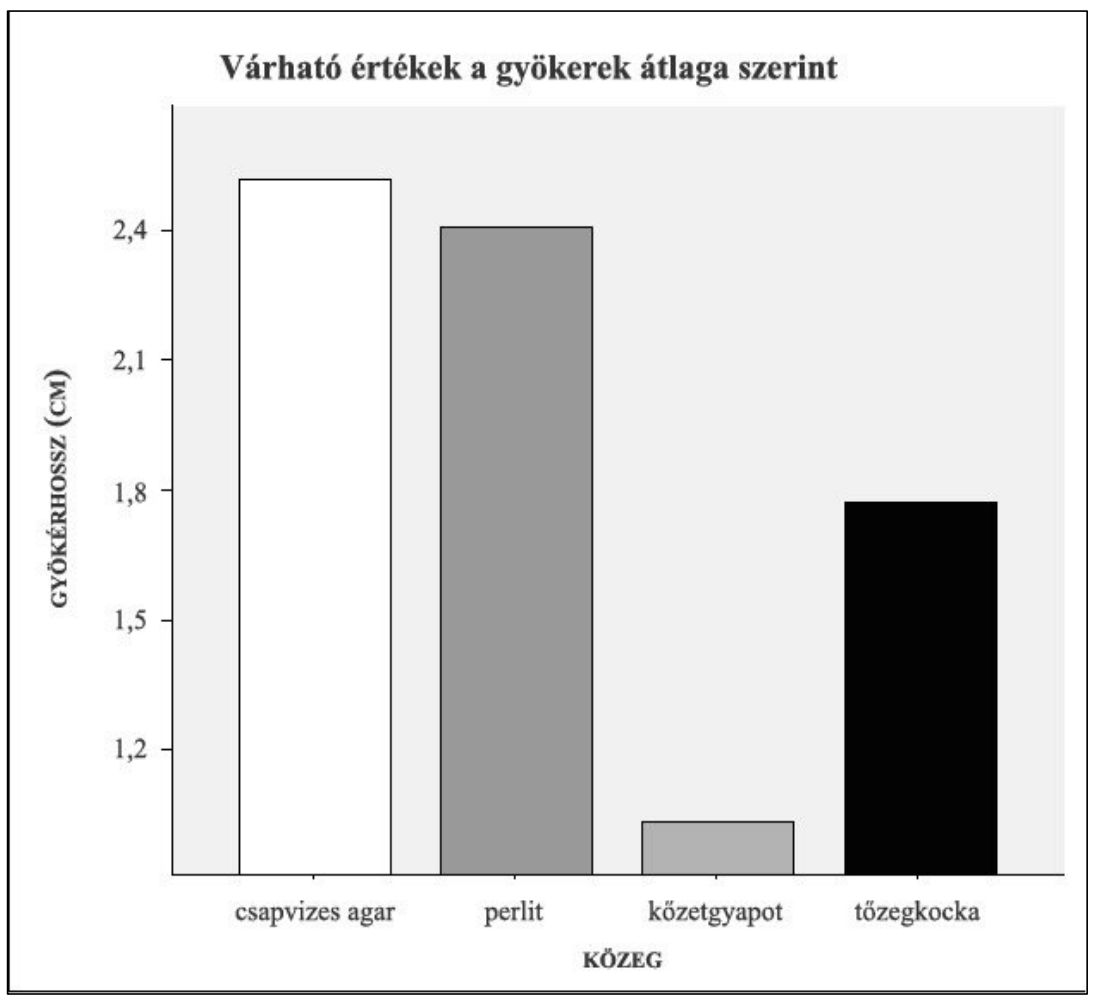

21. ábra: A gyökerek átlagos hosszúsága csapvizes agarban, perlitben, kőzetgyapotban és tőzegkockában.
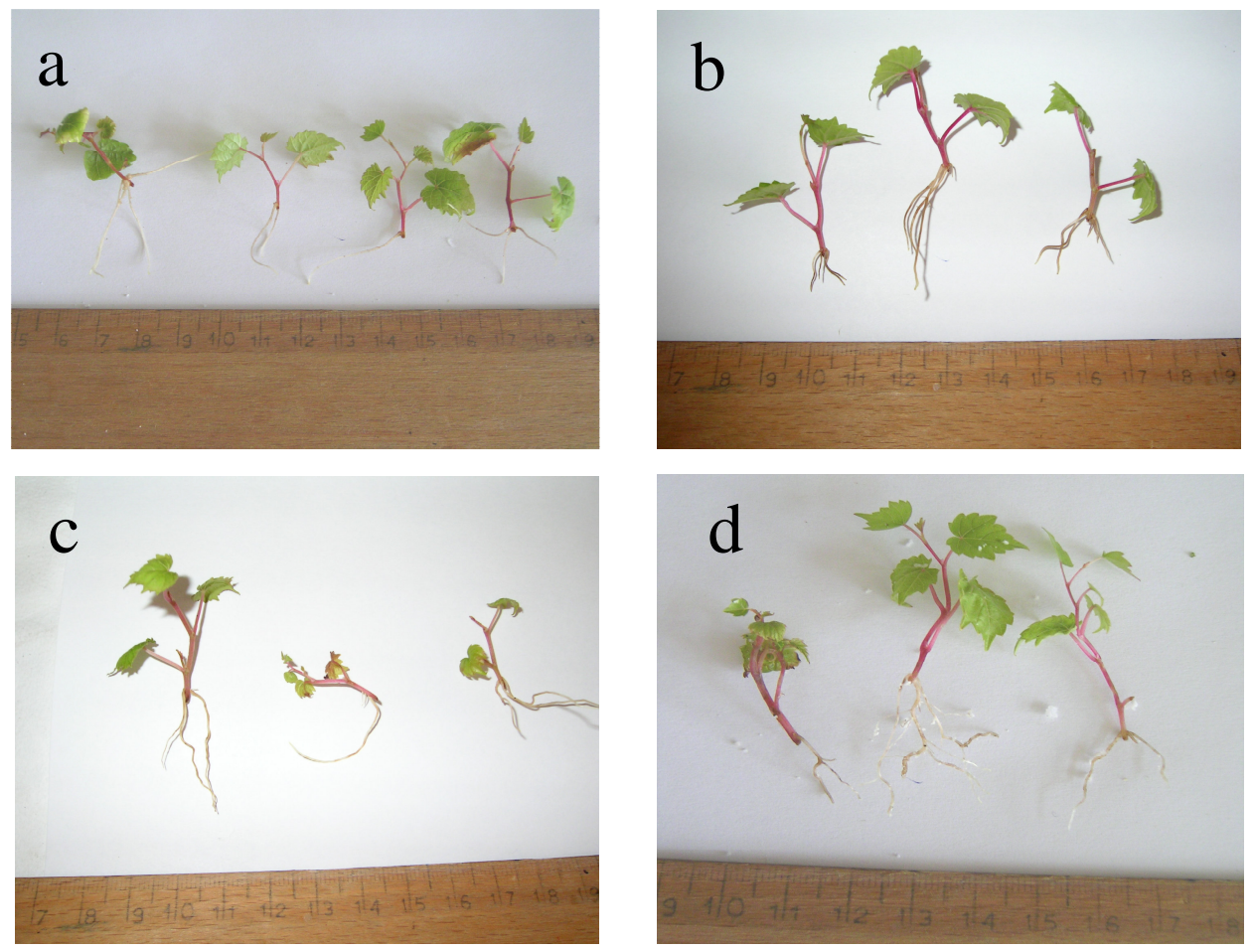

22. ábra: Csapvizes agarban (a), kőzetgyapotban (b), tőzegkockában (c) és perlitben (d) gyökereztetett 'Richter 110' mikrodugványok. 
A fóliával illetve a szivacsos tetővel fedett üvegekben gyökereztetett mikrodugványok között nem találtunk szignifikáns különbséget a gyökerek számát illetően. Az egy növényen lévő gyökerek összes hosszát illetően és az alapján, hogy hány centiméter volt a gyökerek átlagos hossza (23. ábra) már szignifikáns különbséget tapasztaltunk. Ez azt mutatja, hogy a szivacsos tetővel való fedés előnyösebb a háromrétegü fóliafedéssel szemben a 'Richter 110' alanyfajta esetében. A fóliával illetve a szivacsos tetővel fedett edényekben is csaknem 100\%-ban meggyökeresedtek a növények, de a három réteg fólia valamelyest akadályozta az üvegek levegőzését. Ezért a szivacsos tetővel való fedés hatékonyabbá teheti az in vitro nevelt növények gyökeresítését.
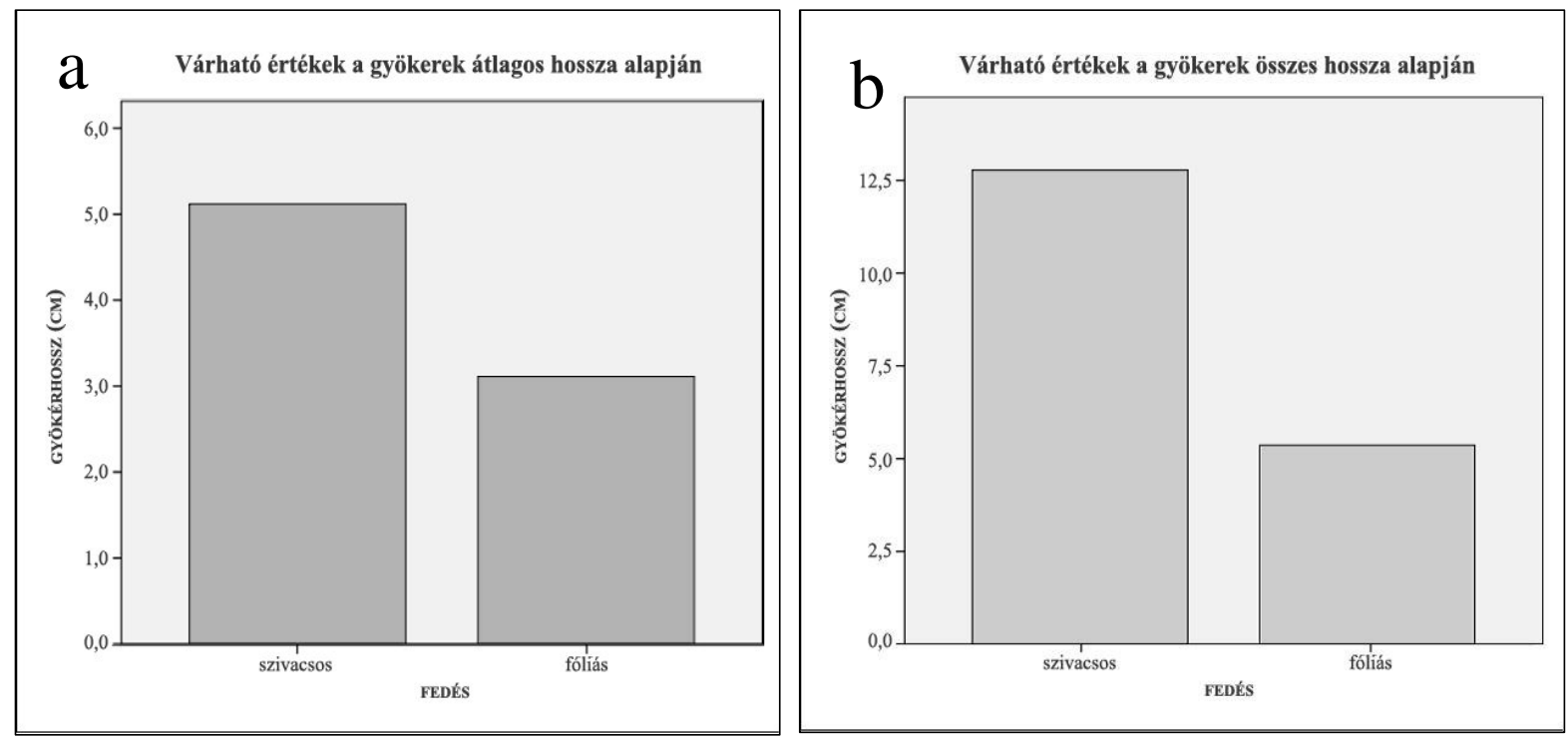

23. ábra: A gyökerek növényenkénti átlagos (a) és összes (b) hossza a szivacsos tetővel illetve a fóliával fedett üvegekben.

\section{Az EHA105(pRok2Ferr), EHA105(pRok2FerrFLAG), EHA105(pRok2),} EHA101(pTd93virE1), EHA101(pJP17) vektorral transzformált 'Richter 110' növényekröl származó kétrügyes mikrodugványokat a kapott eredmények alapján steril csapvízzel nedvesített perlittel megtöltött bébiételes üvegekben gyökereztettük fényszobában, $24^{\circ} \mathrm{C}$ on 16 órás megvilágítás mellett. 18-20 nap elteltével, miután a mikrodugványok meggyökeresedtek, a bébiételes üvegek tetejét fokozatosan megnyitottuk, majd teljesen eltávolítottuk. Ezt követően a gyökeres mikrodugványokat megfelelő tápanyagokat tartalmazó perlit és tőzeg 1:1 arányú keverékével megtöltött cserepekbe ültettük. A szőlő növényeket üvegházban természetes megvilágítás és $20^{\circ} \mathrm{C}$ körüli hőmérséklet mellett 
neveltük tovább, párásítást naponta egy alkalommal végeztünk. Az EHA101(pJP17-S4) vektorral transzformált növények akklimatizációja folyamatban van.

A pTd93virE1 transzformáns 'Richter 110' növények akklimatizációja során megfigyeltük, hogy azok csökkent életképességgel rendelkeznek. Üvegházi körülmények között vált egyértemüen láthatóvá, hogy törpe növekedésủek és elszáradó hajtáscsúcsokkal rendelkeznek, ebből kifolyólag pedig nem tudtuk felszaporítani őket a különböző agrobaktériumos fertőzési kísérletekhez sem. A 24. ábra a perlit és tőzeg keverékével megtöltött edényekbe ültetett meggyökeresedett pTd93virE1 transzformáns (1. és 2. növény) és a nem-transzformált kontroll (3. és 4. növény) 'Richter 110' mikrodugványok hajtásfejlődése közötti különbségeket mutatja az átültetés után 2 hónappal. A pTd93virE1 transzformáns növények rendellenes növekedésével megegyező tüneteket tapasztaltunk a pRok2FerrFLAG transzformáns növények egy részénél is, ezért ez a jelenség nem tuladonítható egyértelműen a felhasznált konstrukciónak. Véleményünk szerint a szomaklonáris variabilitás állhat a háttérben, melyet az embriogén anyag folyamatos átrakása során felszaporítottunk.

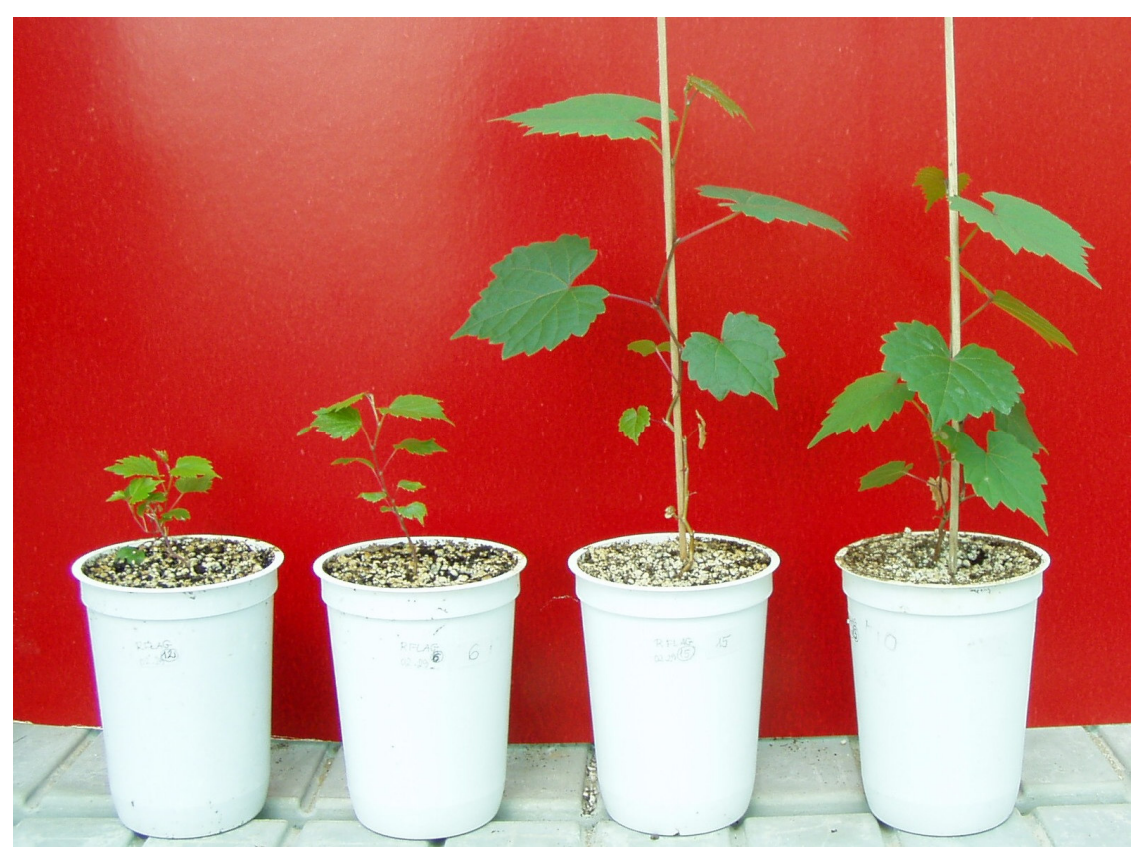

24. ábra: A meggyökeresedett pTd93virE1 transzformáns (1. és 2. növény) és nemtranszformált kontroll (3. és 4. növény) 'Richter 110' mikrodugványok hajtásfejlődése az átültetés után 2 hónappal. 


\subsection{PCR-analízis}

A PCR analízis során célunk a bevitt gének jelenlétének kimutatása és a növényi minta Agrobacterium mentességének bizonyítása volt. Az eljárás során a növényi mintából kivont DNS-ből specifikus primerekkel próbáltuk az MsFerr, iaaM és virE1, nptII és virC (Agrobacterium virulencia gén) gének megfelelő hosszúságú szakaszait amplifikálni. A PCR-reakció során nyert fragmentumokat agaróz gélelektroforézissel választottuk el egymástól. A futtatás után kapott DNS-mintázatot értékeltük. A méret markerrel $(1 \mathrm{~kb}$ DNA Ladder, Promega) történő összehasonlítás során megállapítottuk, hogy a kanamicin rezisztenciát okozó nptII gén keresett szakaszát sikeresen amplifikáltuk az összes vizsgált feltételezett 'Richter 110’ transzformáns DNS mintájából (25. ábra). A vizsgált növényi minták egyikénél sem sikerült az Agrobacterium virC gén megfelelő szakaszát amplifikálni (26. ábra), ami azt mutatja, hogy a keresett gének esetében a pozitív eredményt nem az Agrobacterium sejtek növényben való jelenléte okozza.

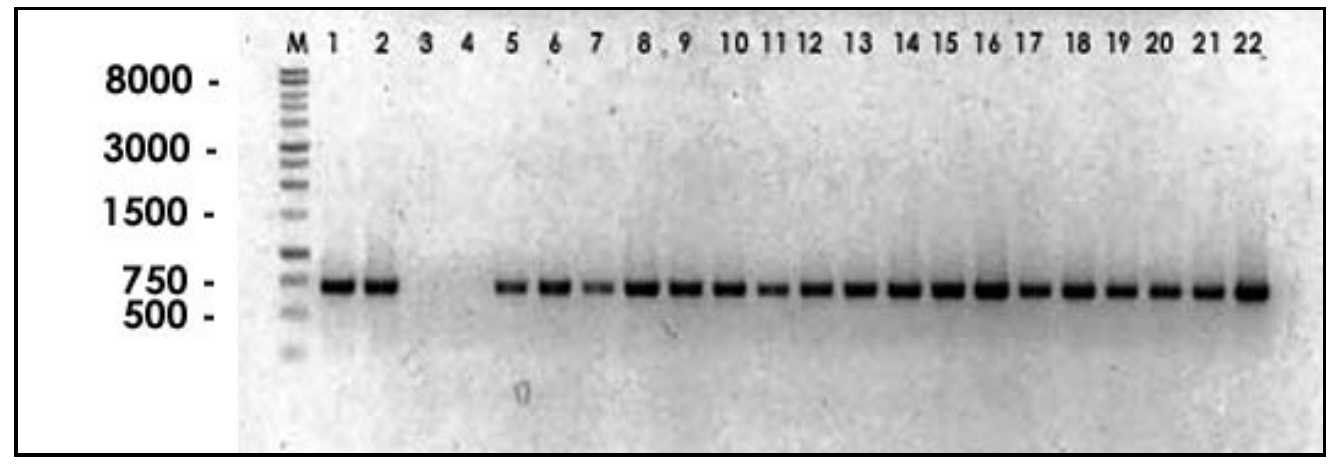

25. ábra: Transzformált DNS szakasz amplifikálása szőlő növényekből nptII specifikus primerekkel. sáv 1-2: A. tumefaciens EHA105(pRok2Ferr) sáv 3: 0 kontroll (templát DNS nélkül) sáv 4: kontroll 'Richter 110' sáv 5-22: 18 független transzformáns 'Richter 110' 


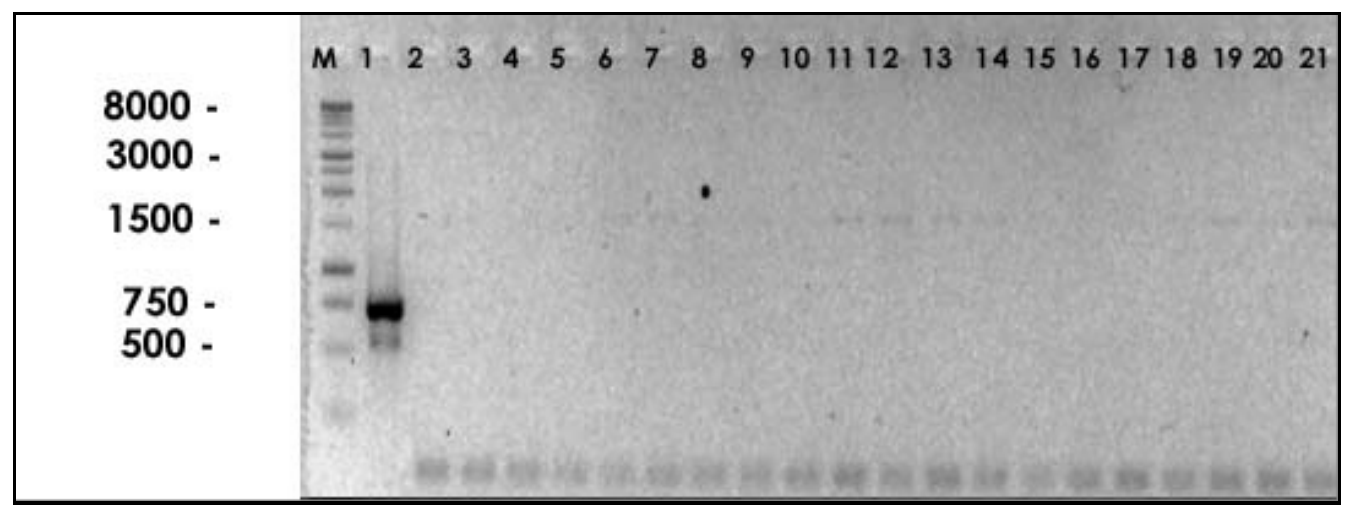

26. ábra: A. tumefaciens DNS szakasz amplifikálása szőlő növényekből virC specifikus primerekkel. sáv 1: A. tumefaciens EHA105(pRok2Ferr) sáv 2: 0 kontroll (templát DNS nélkül) sáv 3: kontroll 'Richter 110' sáv 4-21: 18 független transzformáns 'Richter 110'

A lucerna ferritin gén jelenlétének ellenőrzésére az Oláh Róbert által (2005) kiválasztott, a gén kimutatására alkalmas Fw1-Rev2 primer kombinációt használtuk. A temelődő fehérje kloroplasztiszban történő kifejeződéséért felelős EHA105(pRok2Ferr) vektorral transzformált 'Richter 110' növények mintáiban sikeresen amplifikáltuk a gén 513 bp hosszúságú szakaszát (27. ábra), a fehérje citoplazmában történő felhalmozódását eredményező EHA105(pRok2FerrFLAG) vektorral transzformált növények esetében azonban csak kb. a minták felénél tudtuk amplifikálni a kívánt szakaszt (saját, nem közölt adatok). Az agaróz gélelektroforézissel elválasztott DNS-mintázatot a Promega cég $1 \mathrm{~kb}$ DNA Ladder méretmarkerének segítségével értékeltük.

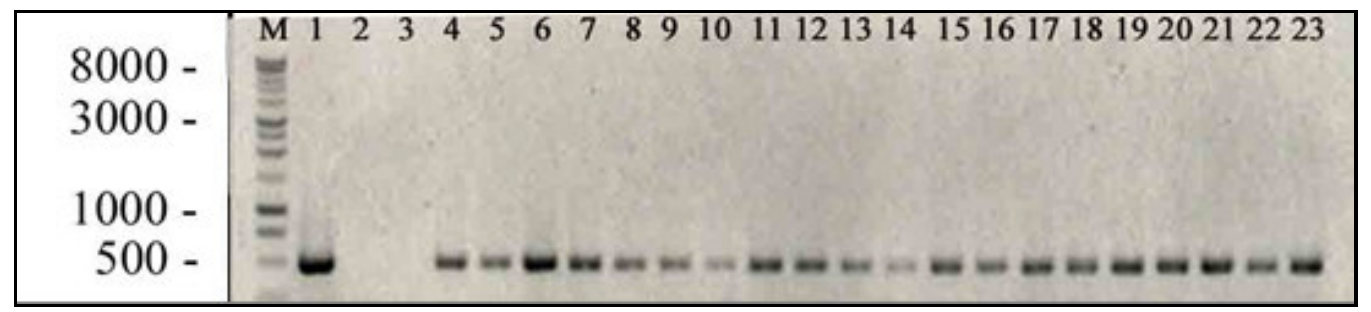

27. ábra: Transzformált DNS szakasz amplifikálása szőlő növényekből MsFerr Fw1-Rev2 primerekkel.

sáv 1: A. tumefaciens EHA105(pRok2Ferr)

sáv 2: 0 kontroll (templát DNS nélkül)

sáv 3: kontroll 'Richter 110'

sáv 4-23: 20 független transzformáns 'Richter 110' 
A Magyar Tudományos Akadémia Szegedi Biológiai Központjának Növénybiológiai Intézetében Horváth V. Gábor és munkatársai elvégezték 16 PCR analízissel alátámasztott pRok2Ferr pozitív 'Richter 110' vonal levélmintáinak mRNS és fehérje szintü vizsgálatait qPCR illetve Western blot analíssel (Zok et al. 2009a., b). A vizsgált növényi mintákban fokozott lucerna ferritin gén expressziót tapasztaltak. A levélminták Western blot analízise során megállapították, hogy a lucerna ferritin fehérje nagy mennyiségben akkumulálódott a levelekben. A keresett fehérje molekuláris súlya alapján a fehérje feldolgozott fomában történő felhalmozódását feltételezték, ahogy az a pRok2Ferr konstrukció alapján várható is volt (lásd 3.6. fejezet).

A géncsendesítés mechanizmusán alapuló, feltételezhetően Agrobacterium rezisztenciát biztosító EHA101(pJP17) és EHA101(pJP17-S4) vektorokkal transzformált 'Richter 110' növények esetében az iaaM gén jelenlétének ellenőrzésére használt primerekekkel az összes vizsgált növényi mintában sikerült a gén 150 bp hosszúságú szakaszát amplifikálni (28. ábra). Az agaróz gélelektroforézissel elválasztott DNSmintázatot a Fermentas cég Low Range DNA Ladder méretmarkerének segítségével értékeltük.

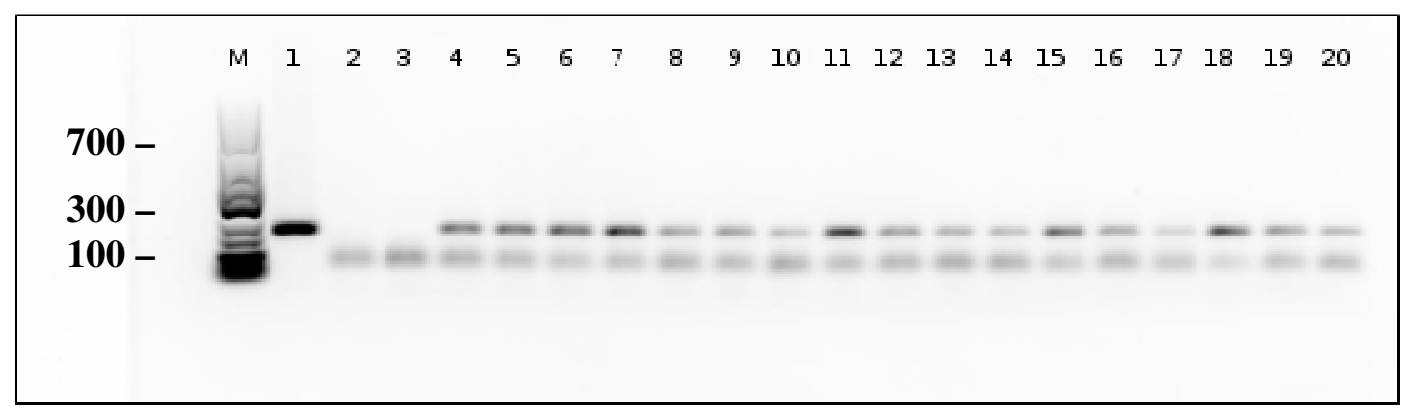

28. ábra: Transzformált DNS szakasz amplifikálása szőlő növényekből iaaM specifikus primerekkel.

sáv 1: A. tumefaciens EHA101(pJP17)

sáv 2: 0 kontroll (templát DNS nélkül)

sáv 3: kontroll 'Richter 110'

sáv 4-20: 16 független transzformáns 'Richter 110'

A VirE1-VirE2 fehérjék komplexképződésére alapozott, feltételezhetően Agrobacterium rezisztenciát biztosító EHA101(pTd93virE1) vektorral transzformált 'Richter 110' növények mintáiban sikeresen amplifikáltuk a gén megfelelő szakaszát virE1 specifikus primerekkel (29. ábra). Az agaróz gélelektroforézissel elválasztott DNSmintázatot a Promega cég 1 kb DNA Ladder méretmarkerének segítségével értékeltük. 


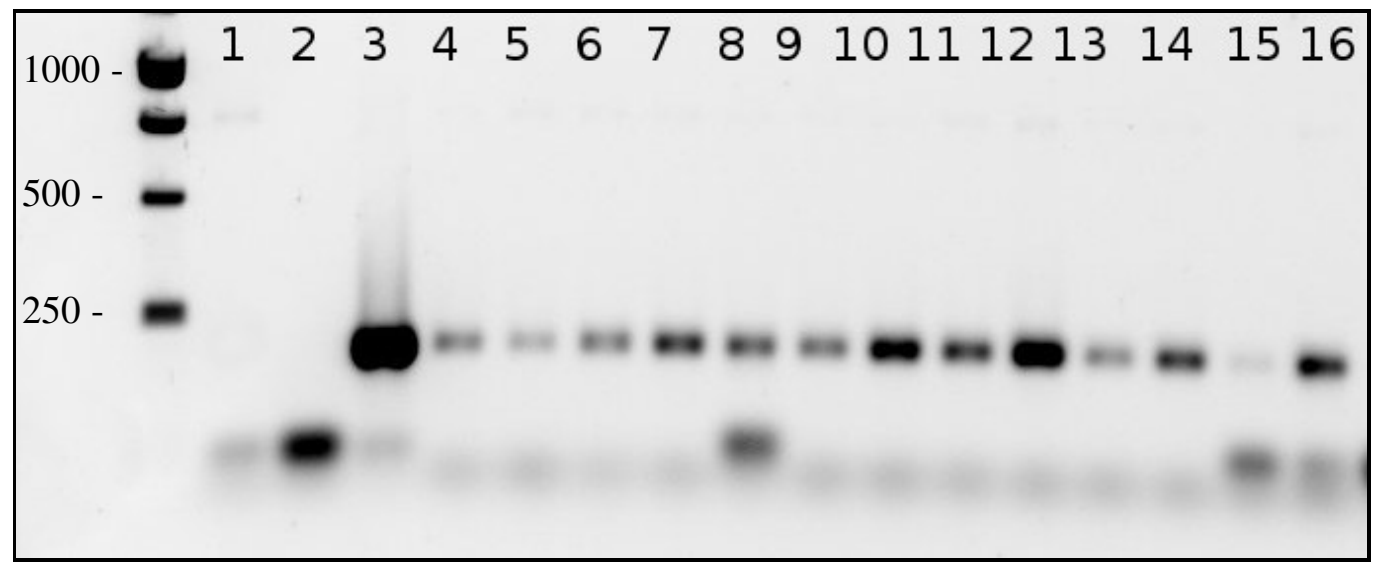

29. ábra: Transzformált DNS szakasz amplifikálása szőlő növényekből virE1 specifikus primerekkel.

sáv 1: kontroll 'Richter 110'

sáv 2: 0 kontroll (templát DNS nélkül)

sáv 3: A. tumefaciens EHA101(pTd93virE1)

sáv 4-16: 13 független transzformáns 'Richter 110'

\subsection{A transzformánsok oxidatív stressztürő képességének tesztelése}

Elvégeztük 6 pRok2Ferr transzformáns 'Richter 110' vonal fiziológiai jellemzését annak érdekében, hogy megállapítsuk, ezek a genotípusok valóban nagyobb oxidatív stressz toleranciával rendelkeznek-e, mint a kísérletben kontrollként felhasznált nemtranszformált 'Richter 110' növény. Vizsgálataink a klorofill fluoreszcencia indukció mérésére terjedtek ki, amikoris a sötétadaptált levélminták PSII reakciócentrumának potenciális kvantitatív teljesítményét az $\quad \mathrm{F}_{\mathrm{v}} / \mathrm{F}_{\mathrm{m}}$ arány meghatározásával mértük. A különböző koncentrációjú paraquat oldatban úsztatott, pRok2Ferr transzformáns és kontroll szőlő növényekről származó levelek fluoreszcencia indukciós mérése során 2 független transzformált vonal (F7 és F9, 30. ábra) esetében tapasztaltunk eltérést a nemtranszformált kontroll 'Richter 110' vonalhoz viszonyítva. A kontroll növényről származó levelek esetében az $\mathrm{F}_{\mathrm{v}} / \mathrm{F}_{\mathrm{m}}$ arány értéke már az $1 \mu \mathrm{M}$ paraquat oldattal történő kezelés után 50\%-kal, majd a koncentráció emelésével folyamatosan tovább csökkent. Az F7 és F9 lucerna ferritint termelő transzformánsok esetében azonban az $\mathrm{F}_{\mathrm{v}} / \mathrm{F}_{\mathrm{m}}$ arány értékben bekövetkezö csökkenés kisebb mértékü volt, a transzgénikus vonalak leveleiben a PSII potenciális kvantitatív teljesítménye még a $4 \mu \mathrm{M}$ paraquat koncentáció mellett sem esett vissza a felére. Amikor a pRok2Ferr transzformáns és kontroll szőlő növények leveleit 
csapvízben úsztattuk, nem tapasztaltunk számottevő különbséget azok fotoszintetikus teljesítményében.

A szőlőtermesztési gyakorlatban a 'Richter 110' fajtát alanynak használják, ezért a pRok2Ferr transzformáns és a nem-transzformált kontroll 'Richter 110' vonalak $50 \mathrm{mM}$ $\mathrm{NaHCO}_{3}$ oldattal történő elárasztása során arra a kérdésre kerestük a választ, hogy vajon a lucerna ferritin fehérjét túltermelő növények a kontroll növényhez képest nagyobb szárazság-, és sóstressz toleranciával rendelkeznek-e. A kísérlet kiértékelésekor - 15 nap elteltével - a kontroll növény estében levélszáradást tapasztaltunk (31.a. ábra), ez a tünet azonban a vizsgált pRok2Ferr transzformáns vonalak egyikén sem jelentkezett, ezen növények levelein helyenként klorotikus tünetek voltak megfigyelhetőek (31.b. és c. ábra). A pRok2Ferr transzformáns szőlő növények esetében a termelődő lucerna ferritin fehérje a kloroplasztiszban lokalizálódik, ezért a szőlőtermesztési gyakorlat számára is hasznosítható információkat csak a pRok2ferrFLAG transzformánsok vizsgálatával nyerhetünk, ahol ez a túltermeltetett fehérje a citoplazmában akkumulálódik. Megfigyeléseink ennek ellenére valószínüsítik, hogy a transzformált vonalak közül néhány esetben az oxidatív stresszel szembeni növekedett ellenálló képesség mutatható ki. 


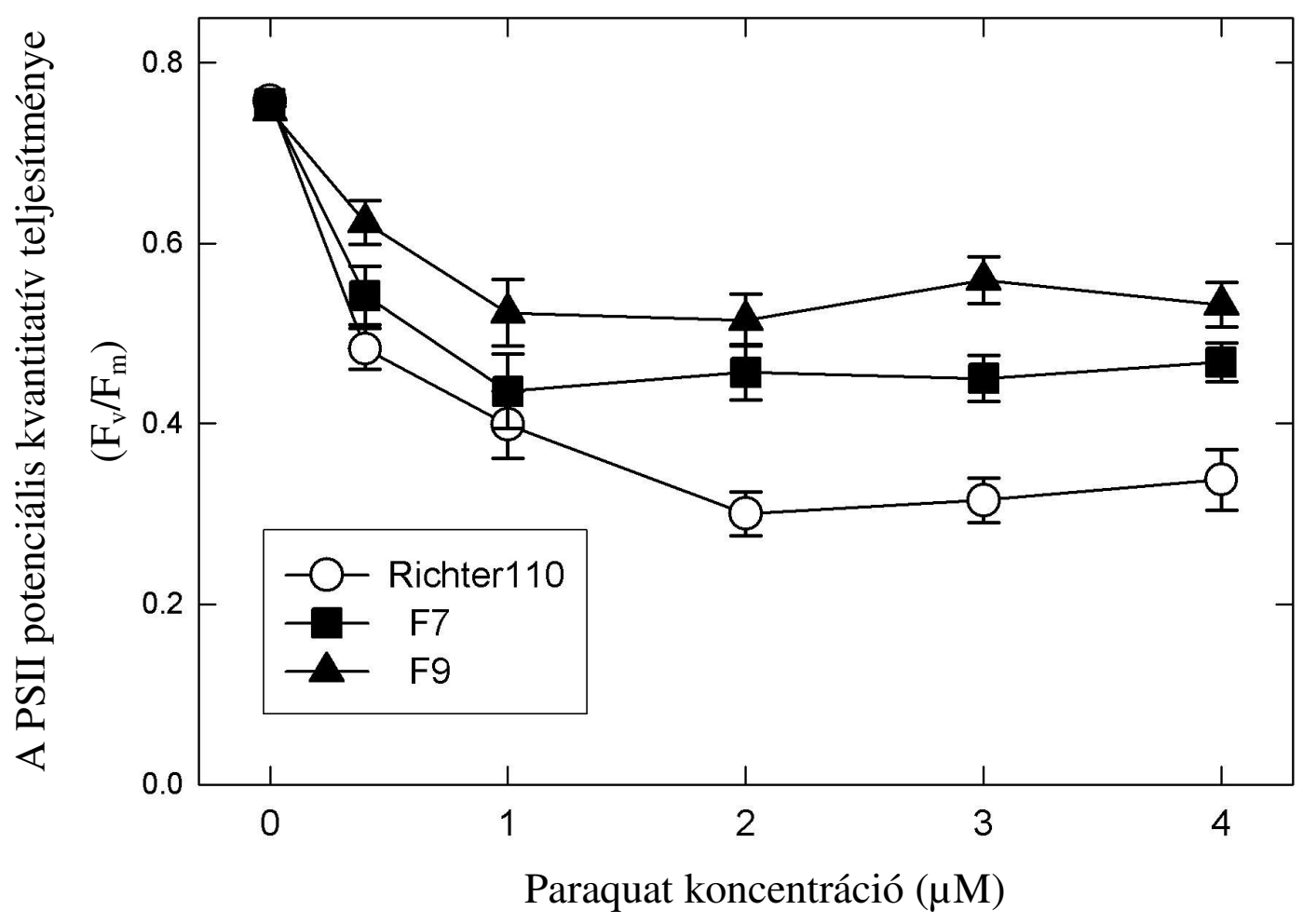

30. ábra: A nem-transzformált kontroll és a pRok2Ferr transzformáns 'Richter 110' növények leveleinek fotoszintetikus teljesítményében bekövetkezett változások a különböző koncentrációjú paraquat oldatokban.

Richter110: nem-transzformált kontroll 'Richter 110'; F7, F9: pRok2Ferr transzformáns 'Richter 110' vonalak.
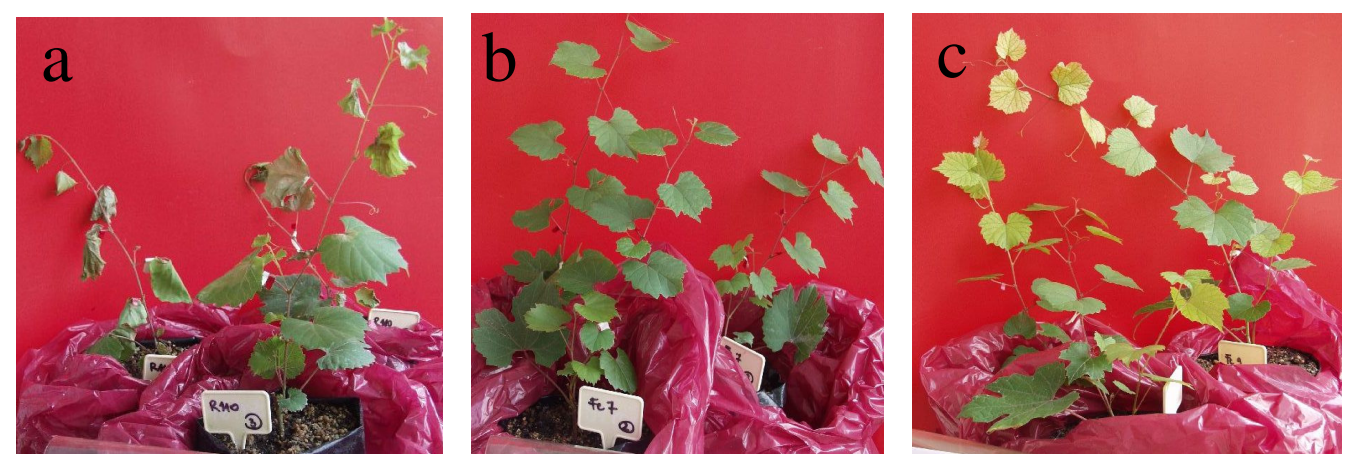

31. ábra: A nem-transzformált kontroll (a) és a pRok2Ferr transzformáns (b, c) 'Richter 110' növények levelein bekövetkezett változások az $50 \mathrm{mM} \mathrm{NaHCO}_{3}$ oldattal történő kezelés hatására. 


\subsection{Agrobacterium rezisztencia vizsgálatok}

Az EHA101(pJP17) vektorral transzformált, bizonyítottan transzgénikus (lásd 5.7. fejezet) 'Richter 110’ növények Agrobacterium rezisztencia vizsgálatainak eredményeit a 8. táblázat tartalmazza. A táblázatban „,+” jelöléssel láttam el azokat a vonalakat, amelyeknél intenzív, „(+)” jelöléssel, amelyeknél gyenge tumorfejlődést tapasztaltunk. Az adott törzzsel szemben egyértelműen ellenálló vonalakat „,-” jelöléssel tüntettem fel. A táblázatban szereplő értékek a fejlődött tumorok/sebzési helyek arányát mutatják. A 21 független vonal mintegy harmada bizonyult egyértelműen rezisztensnek az A348 törzzsel szemben (32. ábra), és ezek közül 3 vonalon az AT1 törzs sem tudott tumorfejlődést indukálni. A C58, Tm4 és S4 Agrobacterium törzsekkel való fertőzés a vizsgált vonalak nagy részén tumorfejlődést eredményezett.

Az A. tumefaciens A348 törzzsel való fertőzés során kapott negatív eredmények valószínủleg azzal magyarázhatóak, hogy a pJP17 konstrukció elkészítésénél ennek a törzsnek az iaaM és ipt szekvenciáit használták fel. Az A. vitis S4 törzzsel való fertőzés mindegyik vizsgált növényen tumorfejlödést eredményezett, ami az A348 és S4 törzsek távoli rokonsági kapcsolatával magyarázható. Eredményeink alapján valószínűsíthető, hogy az alkalmazott eljárással lehetséges Agrobacterium rezisztens szőlő vonalak létrehozása, de az is bebizonyosodott, hogy a patogén törzsekben lévő iaaM szekvenciák közötti eltérések miatt nem lehet egyetlen "védő" szekvenciát tartalmazó, minden törzsnek ellenálló transzgenikus növényt létrehozni. Az A. vitis S4 iaaM szekvenciát is tartalmazó pJP17-S4 konstrukcióval transzformált növények teszteléseit az akklimatizációt követően kívánjuk elvégezni, valamint szeretnénk a pJP17 konstrukcióval transzformált növények fertőzését is megismételni, hogy egyértelmü következtetéseket tudjunk levonni arra vonatkozóan, hogy a konstrukciók eredményesen felhasználhatóak-e szőlöben Agrobacterium rezisztencia kialakítására. 
8. táblázat: Az EHA101(pJP17) vektorral transzformált 'Richter 110' növények A348, C58, Tm4, AT1 és S4 Agrobacterium törzsekkel szembeni ellenállóságának vizsgálata.

\begin{tabular}{|c|c|c|c|c|c|}
\hline Vonal & $\mathrm{A} 348$ & $\mathrm{C} 58$ & $\mathrm{Tm} 4$ & $\mathrm{AT} 1$ & $\mathrm{~S} 4$ \\
\hline${ }^{2} \mathrm{Richter} 110$ & $+2 / 3$ & $+3 / 3$ & $(+) 2 / 3$ & $+2 / 3$ & $+2 / 3$ \\
\hline $\mathrm{pJP} 17 / 3$ & $-0 / 3$ & $(+) 3 / 3$ & $+3 / 3$ & $-0 / 3$ & $+3 / 3$ \\
\hline $\mathrm{pJP} 17 / 4$ & $(+) 2 / 2$ & $(+) 3 / 3$ & $(+) 1 / 3$ & $(+) 3 / 3$ & $+3 / 3$ \\
\hline $\mathrm{pJP} 17 / 5$ & $+3 / 3$ & $+3 / 3$ & $+3 / 3$ & $(+) 3 / 3$ & $+2 / 3$ \\
\hline $\mathrm{pJP} 17 / 6$ & $-0 / 3$ & $(+) 3 / 3$ & $+3 / 3$ & $(+) 3 / 3$ & $+2 / 3$ \\
\hline $\mathrm{pJP} 17 / 9$ & $-0 / 3$ & $(+) 3 / 3$ & $+3 / 3$ & $(+) 3 / 3$ & $+3 / 3$ \\
\hline $\mathrm{pJP} 17 / 21$ & $-0 / 3$ & $(+) 2 / 3$ & $+2 / 3$ & $(+) 3 / 3$ & $\mathrm{n} . \mathrm{t}$ \\
\hline $\mathrm{pJP} 17 / 22$ & $+3 / 3$ & $(+) 3 / 3$ & $(+) 1 / 3$ & $(+) 3 / 3$ & $(+) 2 / 2$ \\
\hline $\mathrm{pJP} 17 / 23$ & $-0 / 3$ & $(+) 3 / 3$ & $+3 / 3$ & $-0 / 3$ & $+3 / 3$ \\
\hline $\mathrm{pJP} 17 / 35$ & $+3 / 3$ & $+3 / 3$ & $+2 / 3$ & $(+) 3 / 3$ & $+3 / 3$ \\
\hline $\mathrm{pJP} 17 / 38$ & $+3 / 3$ & $(+) 3 / 3$ & $(+) 2 / 2$ & $+2 / 3$ & $(+) 2 / 3$ \\
\hline $\mathrm{pJP} 17 / 42$ & $(+) 1 / 3$ & $+3 / 3$ & $(+) 3 / 3$ & $(+) 2 / 3$ & $(+) 3 / 3$ \\
\hline $\mathrm{pJP} 17 / 43$ & $+2 / 3$ & $(+) 3 / 3$ & $+3 / 3$ & $(+) 1 / 3$ & $+3 / 3$ \\
\hline $\mathrm{pJP} 17 / 44$ & $(+) 2 / 3$ & $(+) 3 / 3$ & $+2 / 3$ & $(+) 1 / 3$ & $(+) 2 / 2$ \\
\hline $\mathrm{pJP} 17 / 46$ & $(+) 3 / 3$ & $(+) 3 / 3$ & $+1 / 3$ & $(+) 3 / 3$ & $+2 / 3$ \\
\hline $\mathrm{pJP} 17 / 48$ & $(+) 1 / 3$ & $(+) 3 / 3$ & $-0 / 3$ & $(+) 2 / 3$ & $+2 / 3$ \\
\hline $\mathrm{pJP} 17 / 50$ & $(+) 1 / 3$ & $(+) 3 / 3$ & $+2 / 2$ & $(+) 3 / 3$ & $(+) 3 / 3$ \\
\hline $\mathrm{pJP} 17 / 57$ & $-0 / 3$ & $(+) 2 / 3$ & $+2 / 3$ & $(+) 2 / 3$ & $+2 / 3$ \\
\hline $\mathrm{pJP} 17 / 58$ & $-0 / 3$ & $(+) 3 / 3$ & $+2 / 3$ & $(+) 1 / 3$ & $+1 / 3$ \\
\hline $\mathrm{pJP} 17 / 61$ & $+2 / 2$ & $(+) 3 / 3$ & $+3 / 3$ & $(+) 1 / 3$ & $+3 / 3$ \\
\hline $\mathrm{pJP} 17 / 62$ & $-0 / 3$ & $+3 / 3$ & $+3 / 3$ & $-0 / 3$ & $+3 / 3$ \\
\hline $\mathrm{pJP} 17 / 63$ & $+1 / 3$ & $(+) 3 / 3$ & $+3 / 3$ & $+3 / 3$ & $+2 / 3$ \\
\hline
\end{tabular}

nt: nem tesztelt

+ intenzív tumorfejlődés

(+) gyenge tumorfejlődés

- nincs tumorfejlödés

fejlődött tumorok/sebzési helyek
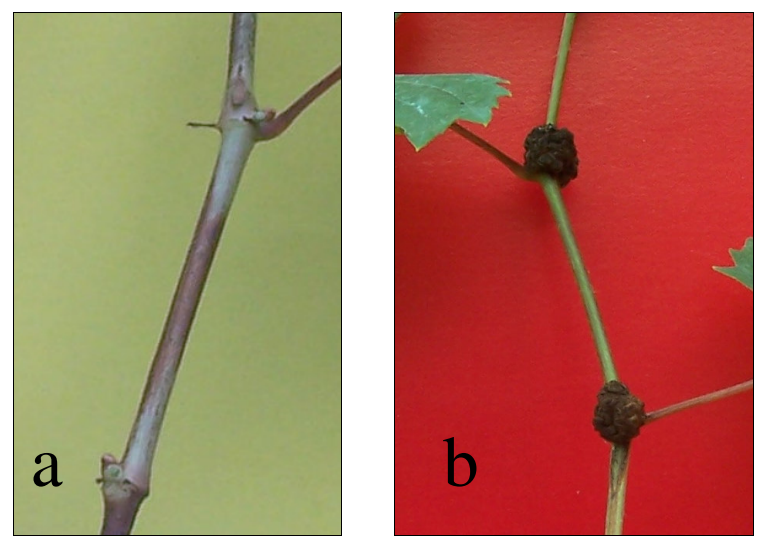

32. ábra: Agrobacterium tumefaciens A348 törzzsel szemben ellenálló (a) és fogékony (b) EHA101(pJP17) vektorral transzformált 'Richter 110' növények másfél hónappal a fertőzés után. 
Az EHA101(pTd93virE1) vektorral transzformált növények Agrobacterium rezisztencia vizsgálatai során az akklimatizált növények esetében 8 növény rezisztensnek 5 növény pedig fogékonynak bizonyult az A. vitis Tm4 törzzsel szemben. A fényszobából származó növények esetében a rezisztens és fogékony növények megoszlása 17:9 volt (33. ábra). Az in vitro körülmények között nevelt és fertőzött növényeknél megfigyeltük, hogy a tumorfejlődés a fogékony növényeken sokkal egyértelműbb volt (morfológiailag egyértelmủen meghatározható), mint az akklimatizált növényeken. Ez a különbség valószínüleg az eltérö szöveti struktúrával magyarázható. Mivel a növények csökkent életképessége miatt nem tudtuk azokat felszaporítani és így csak egy Agrobacterium törzzsel végeztük el a fertőzéseket, ezért egyértelmü következtetéseket nem tudtunk levonni arra vonatkozólag, hogy EHA101(pTd93virE1) vektor alkalmas-e a szőlőben Agrobacterium rezisztencia kialakítására. Ehhez egy új transzformációs kísérlet elvégzésére lenne szükség.
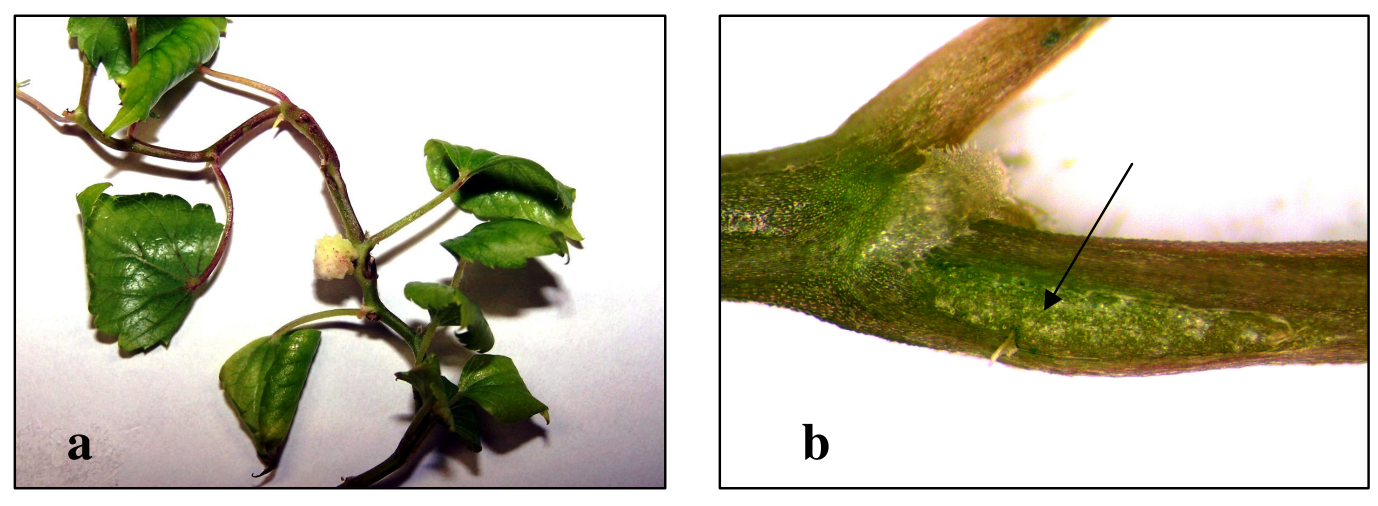

33. ábra: Az EHA101(pTd93virE1) vektorral transzformált, in vitro körülmények között nevelt és fertőzött fogékony (a) és ellenálló (b) 'Richter 110’ növények az Agrobacterium vitis Tm4 törzzsel való fertőzés után másfél hónappal.

A $V$. amurensis eredetü, tanszéki nemesítésü fajták Agrobacterium rezisztencia vizsgálatainak eredményeit a 9. táblázat tartalmazza. A táblázatban feltüntettem az adott törzzsel fertőzött növények számát, az érzékenység fokát („,+”: fogékony, „,(+)”: gyengén fogékony, ,-": rezisztens), a zárójelben szereplő értékek pedig a fejlődött tumorok / sebzési helyek arányát mutatják. A tesztelt fajták közül a 'Korai bíbor' és 'Orpheus' az $A$. tumefaciens C58 törzzsel szemben; az 'Odysseus' és 'Pannon frankos' az A. tumefaciens C58, A. vitis AT1 és S4 törzsekkel szemben bizonyult rezisztensnek. A 'Taurus' mind az 5 Agrobacterium törzzsel szemben egyértelmüen rezisztensnek bizonyult. A kísérletet ezen a 
fajtán a következő évben is megismételtük, kibővítve még néhány újabb Agrobacterium törzzsel (A. tumefaciens A348, A. vitis AB4 és Sz1) és ekkor is egyértelmü rezisztenciát tapasztaltunk. Ezután elvégeztük a 'Taurus' öntermékenyítéséből származó utódok vizsgálatát, és a kapott 33 rezisztens : 20 fogékony hasadási arányból arra következtetésre jutottunk, hogy a tulajdonság monogénesen öröklődik és a rezisztencia kialakulásáért domináns allél felelős.

9. táblázat: A Vitis amurensis eredetü tanszéki nemesítésü fajták Agrobacterium rezisztencia vizsgálatainak eredményei.

\begin{tabular}{|c|c|c|c|c|c|c|}
\hline Fajta & $\begin{array}{c}\text { Kontroll } \\
(0)\end{array}$ & $\begin{array}{c}\text { A. tumefaciens } \\
\text { C58 }\end{array}$ & $\begin{array}{c}\text { A. vitis } \\
\text { Tm4 }\end{array}$ & $\begin{array}{c}\text { A. vitis } \\
\text { AB3 }\end{array}$ & $\begin{array}{c}\text { A. vitis } \\
\text { AT1 }\end{array}$ & $\begin{array}{l}\text { A. vitis } \\
\text { S4 }\end{array}$ \\
\hline $\begin{array}{l}\text { 'Kékfrankos' } \\
\text { (+ kontroll) }\end{array}$ & $\begin{array}{l}3- \\
(0 / 7)\end{array}$ & $3-(1 / 7)$ & $3+(8 / 9)$ & $3+(8 / 9)$ & $3+(9 / 9)$ & $3+(9 / 9)$ \\
\hline $\begin{array}{l}\text { 'Szürkebarát' } \\
\text { (+ kontroll) }\end{array}$ & $3-(0 / 9)$ & $3-(1 / 9)$ & $\begin{array}{c}3+ \\
(10 / 10)\end{array}$ & $3+(9 / 9)$ & $3+(6 / 9)$ & $\begin{array}{l}3(+) \\
(8 / 8)\end{array}$ \\
\hline $\begin{array}{l}\text { 'Kunbarát' } \\
\text { (- kontroll) }\end{array}$ & $3-(0 / 8)$ & $3-(0 / 8)$ & $3-(0 / 6)$ & $3-(0 / 9)$ & $3-(0 / 9)$ & $3-(0 / 7)$ \\
\hline 'Pegazus' & $\begin{array}{l}3- \\
(0 / 6)\end{array}$ & $3+(9 / 9)$ & $3+(9 / 9)$ & $2+(6 / 6)$ & $3+(9 / 9)$ & $3+(9 / 9)$ \\
\hline $\begin{array}{l}\text { 'Csépi } \\
\text { muskotály’ }\end{array}$ & $2-(0 / 5)$ & $3(+)(3 / 8)$ & $3+(8 / 8)$ & $2+(5 / 6)$ & $3+(9 / 9)$ & $2+(4 / 6)$ \\
\hline 'Borostyán' & $3-(0 / 9)$ & $3(+)(6 / 9)$ & $3+(8 / 8)$ & $2+(6 / 6)$ & $3+(9 / 9)$ & $3+(9 / 9)$ \\
\hline 'Odysseus' & $3-(0 / 9)$ & $3-(0 / 8)$ & $3+(4 / 7)$ & $3+(9 / 9)$ & $3-(0 / 9)$ & $3-(0 / 9)$ \\
\hline 'Orpheus' & $3-(0 / 7)$ & $3-(0 / 8)$ & $3+(8 / 9)$ & $\begin{array}{l}3(+) \\
(8 / 9) \\
\end{array}$ & $3+(8 / 9)$ & $\begin{array}{l}3(+) \\
(4 / 8)\end{array}$ \\
\hline 'Taurus' & $3-(0 / 9)$ & $3-(0 / 8)$ & $3-(0 / 8)$ & $3-(0 / 9)$ & $3-(0 / 8)$ & $1-(0 / 3)$ \\
\hline 'Korai bíbor' & $3-(0 / 9)$ & $3-(0 / 7)$ & $3+(7 / 8)$ & $3+(8 / 9)$ & $\begin{array}{l}3(+) \\
(1 / 9)\end{array}$ & $\begin{array}{l}3(+) \\
(6 / 9)\end{array}$ \\
\hline 'Pannon frankos' & $3-(0 / 9)$ & $3-(1 / 9)$ & $3(+)(8 / 8)$ & $\begin{array}{l}3(+) \\
(9 / 9)\end{array}$ & $3-(0 / 9)$ & $3-(0 / 9)$ \\
\hline
\end{tabular}

+ intenzív tumorfejlődés

(+) gyenge tumorfejlödés

- nincs tumorfejlődés

fertőzött növények száma, az érzékenység foka, (fejlődött tumorok/sebzési helyek) 


\subsection{0. Új tudományos eredmények}

1. Elsőként sikerült embriogén kallusz fejlődést indukálnunk a 'Korai bíbor', 'Odysseus', 'Orpheus' és 'Pannon frankos’ fajták tenyészeteiben

2. Elsőként próbáltuk ki és sikeresen alkalmaztuk az 1,1 mg/l 2,4-D-t és 0,1 mg/l BA-t tartalmazó Cheé és Pool (1987) által leírt, szőlőre optimalizált táptalajt, embriogén kallusz felszaporítására a 'Richter 110' alanyfajta esetében.

3. Bizonyítottuk, hogy az $0,22 \mathrm{mg} / \mathrm{l}$ BA használata a szelekciós táptalajban növeli az EHA105(pRok2Ferr) vektorral transzformált 'Richter 110' embriogén kultúrák regenerációs hatékonyságát az abnormális fejlődésü embriók arányának csökkentése által.

4. Megállapítottuk, hogy a 'Richter 110' fajta számára a perlitben történő gyökereztetés a legmegfelelőbb eljárás az akklimatizáció hatékonyságának növelése érdekében.

5. Transzgénikus 'Richter 110' növényeket állítottunk elő az EHA105(pRok2Ferr) és EHA105(pRok2FerrFLAG) vektorkonstrukciók felhasználásával a szőlő oxidatív stressztürő képességének növelésére irányuló kísérleteinkben.

6. Két transzgénikus vonalról bebizonyítottuk, hogy a nem-transzformált 'Richter 110’ kontroll vonalhoz képest nagyobb oxidatív stressz toleranciával rendelkeznek.

7. Transzgénikus 'Richter 110' növényeket állítottunk elő az EHA101(pTd93virE1), EHA101(pJP17) és EHA101(pJP17-S4) vektorkonstrukciók felhasználásával az Agrobacterium rezisztens szőlő növények előállítását célzó kísérleteinkben.

8. Megállapítottuk, hogy a pJP17 konstrukció csak azon törzzsel szemben biztosít rezisztenciát, amelynek iaaM és ipt szekvenciáit a konstrukció elkészítésénél felhasználták.

9. A tanszéki nemesítésü fajták Agrobacterium rezisztencia vizsgálatai során megállapítottuk, hogy a 'Korai bíbor' és 'Orpheus' az A. tumefaciens C58 törzzsel szemben; az 'Odysseus' és 'Pannon frankos' az A. tumefaciens C58, A. vitis AT1 és S4 törzsekkel szemben; a 'Taurus' pedig mind az 5 Agrobacterium törzzsel szemben rezisztens. 


\section{EREDMÉNYEK MEGVITATÁSA}

\section{Embriogén kallusz indukció és felszaporítás}

A transzformációs módszerek alkalmazásának lehetősége a regenerációs rendszer meglétén, illetve a fajták regenerációs hatékonyságán múlik. A szőlő regenerációs rendszerek közül számos fajtánál a portokon indukált embriogén sejttenyészeteket alkalmazzák és saját kísérleteink is ezen a területen bizonyultak a legeredményesebbnek. Az MSE táptalaj használata a legtöbb fajta (9) esetében sikeresnek bizonyult az embriogén kallusz indukciós kísérletekben, ami egyértelműen jelzi a 2,4-D és BA hormonkombináció hatékonyságát, melyet korábbi kísérletek is alátámasztanak: Mozsár és Süle (1994), Perrin és mtsai. (2004), López-Pérez és mtsai. (2005) és Pino-Sintra (2007). Az MST táptalaj alkalmazásával a 'Richter 110' és a 'Teleki 5C' alanyfajták portoktenyészetein 8-, ill. 6,67\%-ban sikerült embriogén kallusz fejlödést indukálni. A kapott értékek jelentős mértékben különböznek a 'Chardonnay' és 'Kékfrankos' V. vinifera fajták eredményeitől $(0,25 \%$ ill. 1,25\%). Oláh és munkatársai (2003a) a TDZ $(0,05 \mathrm{mg} / \mathrm{l})$ tartalmú táptalajt szintén eredményesen használták több alanyfajta esetében is ('Börner', 'Richter 110', 'SO4', 'St. George', 'Teleki 5C'). A 'Pannon frankos' fajta esetében csak az NNE táptalajon tapasztaltunk embriogén kallusz fejlődést, ezért véleményünk szerint a táptalaj hatása erősen genotípus függő. Yang és munkatársai (2006) 2,4-D és BA hormonkombinációt tartalmazó (Mauro et al. 1986) szilárd NN táptalajt alkalmazva sikeresen indukáltak embriogén kalluszt különböző $V$. vinifera fajtákról származó portokokon; valamint csak 2,4-D-t tartalmazó NN táptalajon, éretlen zigotikus embriókon. Az MS táptalajhoz képest a NN táptalaj egyes mikroelemekböl (Mn, Mo, Zn, B) többet tartalmaz, makroelem tartalma viszont csökkentett. A szőlőfajták esetében megfigyelt különbségek rávilágítanak arra, hogy a makro-, és mikroelemek mennyiségének illetve minőségének változtatása a táptalajban, valamint a különböző növényi növekedés szabályozó anyagok jelentős mértékben befolyásolják az embriogén kallusz indukciót.

A ‘Chardonnay’ virágzatok sterilizációja során alkalmazott két különböző sterilizálási eljárás ugyanolyan hatékonysággal müködött, ezért a szőlő esetében a $\mathrm{NaOCl}$ oldat helyett a klór-mentes $\mathrm{Ca}(\mathrm{OH})_{2}$ oldat használatát javasoljuk erre a célra. Chée és Pool (1987) in vitro szőlő hajtástenyészeteikben figyelték meg a csökkentett klórtartalmú táptalaj használatának pozitív hatását. A kísérletben felhasznált négyféle táptalaj közül az MSE és CPE táptalajokon közel azonos hatékonysággal sikerült embriogén kalluszt 
indukálnunk. Bouamama és munkatársai (2009) szintén sikeresen indukáltak embriogén kalluszt CP táptalajon, azzal a különbséggel, hogy az általuk felhasznált táptalaj a 2,4-D és TDZ hormonkombinációt tartalmazta. Az antioxidánssal és fenolkötő vegyülettel kiegészített MSE táptalaj használata negatív hatással volt az embriogén kallusz indukcióra, ezért ezekben a kísérletekben nem javasoljuk a használatát. Az aktív szénnel kiegészített MSE táptalaj szintén gátló hatással volt az embriogén kallusz indukcióra. Ez a hatás valószínüleg azzal magyarázható, hogy az aktív szén alkalmazásának van egy olyan mellékhatása, hogy lecsökkenti a hormonok és más szerves anyagok szintjét a táptalajban (Ebert and Taylor 1990).

Az embriogén kallusz indukció a különböző környezeti tényezők miatt nem minden évben müködik azonos hatékonysággal, ezért fontos a már meglévő kallusz tenyészeteinket a lehető legjobb minőségben megőrizni és fenntartani. Az embriogén tenyészetek fenntartása és felszaporítása azonban számos fajta esetében problémát jelentett. A 'Richter 110' alanyfajta esetében kipróbált, és sikeresen alkalmazott 1,1 mg/l 2,4-D-t és 0,1 mg/1 BA-t tartalmazó, Cheé és Pool (1987) által leírt, szőlőre optimalizált táptalaj használata megoldást jelenthet ezekre a problémákra.

\section{Szőlő organogenezis}

Munkánk során a portok indukciós kísérletek mellett megpróbáltunk direkt organogenezissel a rügyalapból növényregenerációt előidézni. A vizsgált 'Richter 110' fajta esetében azonban ez a módszer nem müködött megfelelő hatékonysággal. A 'Richter 110’ fajtánál tapasztalt csekély regenerációs hatékonyság ellenére a módszer alkalmazásának lehetőségét abban látjuk, hogy megoldás lehet génbevitelre olyan fajtáknál, amelyeknél jelenleg nem tudunk embriogén kalluszt létrehozni.

\section{A növényregeneráció hatékonyságának optimalizálása}

Tapasztalataink szerint az embriogén tenyészetek kora jelentősen befolyásolja a regenerációs képességet és a sejttenyészetek homogenitását. Mivel a homogén sejtkultúrák nagyobb regenerációs potenciállal rendelkeznek (Jayasankar et al. 2003), mint a különböző sejtaggregátumokat tartalmazó heterogén tenyészetek, a 'Richter 110', 'Teleki 5C' és 'Chardonnay' fajták esetében sikeresen alkalmazott folyékony MSNOA táptalaj használata megoldást jelenthet a legoptimálisabb állapotú, kis vakuolumokkal rendelkező, gyorsan osztódó sejtek felszaporítására. Az embriogén szuszpenziók használatának előnyeire számos publikáció hívja fel a figyelmet (pl. Coutos-Thévenot et al. 1992, Amar et al. 
2007), Vidal és munkatársai (2003) pedig a genetikai módosítások leghatékonyabb kiindulási anyagának tartják a szuszpenziós kultúrákat.

A hormonmentes CP táptalaj használata a 'Chardonnay' fajta esetében pozitív hatással volt a szomatikus embriók regenerációjára. A táptalaj kedvező hatása a szőlő in vitro tenyészetekre valószínűsíthetően annak köszönhető, hogy a kálciumot nem kálciumklorid hanem kálcium-nitrát formában tartalmazza, emellett a jód és a mangán csökkentett koncentrációban van jelen a táptalajban. Cheé és Pool (1987) a két elem koncentrációjának megváltoztatásával tömeges hajtás differenciációt tapasztalt, amely mindkét ionnak az auxin metabolizmusban és transzportban betöltött szerepével magyarázható.

Az EHA105(pRok2Ferr) vektorral transzformált rendellenes fejlődésü 'Richter 110' szomatikus embriók esetében a $0,22 \mathrm{mg} / \mathrm{l}$ BA használata a szelekciós táptalajban alkalmasnak bizonyult az abnormális fejlődésü transzformált embriók regenerációs hatékonyságának növelésére. Valerii és munkatársai (2003) az IAA és a BA hormonok hatásának szőlő regenerációs kísérletekben történő vizsgálatakor szintén azt tapasztalták, hogy a BA kedvező hatással van a sziklevéllel rendelkező szomatikus embrioidok további fejlődésére. A transzformációs kísérletekben gyakran tömegesen előforduló rendellenes fejlődésű embriók regenerációs idejének lerövidítésében az embriók pusztuló gyökérnyaki részének eltávolítása, vagy a szelekciós ágens táptalajból való megvonása (megfelelö hosszúságú szelekciós periódus után) nyújthat segítséget. A rendellenes fejlődésű embriók pusztuló győkérnyaki részének eltávolítását Perl és munkatársai javaslatára végeztük el, elmondásaik szerint ez a módszer náluk is hasonló erdménnyel működött.

\section{Akklimatizáció}

A transzformált növények akklimatizációs hatékonyságának növelése érdekében végzett kísérleteink során megtaláltuk a 'Richter 110' fajta számára legmegfelelőbb gyökereztetési eljárást. A módszer előnye, hogy olcsó, egyszerủen kivitelezhető, valamint a kiültetés előtti további felszaporítás és akklimatizáció egy lépésben megoldható, amely gazdaságossá teszi. A perlit inorganikus, levegős közeg, akklimatizációkor nem fertőződik. Az üvegházi kiültetés során nem kell a növény gyökereiről eltávolítani a közeget, mint az agaros táptalajok esetében, amikor sok gyökér leszakadhat, és a növény is sérülhet. A megfelelő minőségű gyökérzet megléte esetén pedig nő az adaptáció hatékonysága az akklimatizáció során. 


\section{Szőlőtranszformáció}

A regenerációs rendszer hatékonyságának növelése érdekében végzett kísérleteink eredményeit felhasználva mind a hat konstrukció esetében sikerült a további kísérletekhez szükséges (min. 20) transzformált vonalat regenerálnunk. A transzgének jelenlétét PCR reakcióval igazoltuk. Horváth V. Gábor és munkatársai a pRok2Ferr transzformáns 'Richter 110' vonalak levélmintáinak mRNS és fehérje szintü vizsgálatait is elvégezték (Zok et al. 2009a., b).

\section{A transzformánsok oxidatív stressztürő képességének tesztelése}

A vizsgált pRok2Ferr transzformáns 'Richter 110' vonalak fiziológiai jellemzése során a két transzgénikus vonal esetében tapasztalt megnövekedett oxidatív stressz tolerancia valószínűsíti a szója ferritin fehérje szőlőlevelekben kifejtett pozitív hatását, ahogy azt Deák és munkatársai (1999) korábban, dohány transzformációs kísérleteikben is megfigyelték.

\section{Agrobakérium rezisztencia vizsgálatok}

Az EHA101(pJP17) vektorral transzformált 'Richter 110' vonalak Agrobacterium fertőzése során leggyakrabban az A348 törzzsel szemben tapasztaltunk rezisztenciát. Mivel a géncsendesítés mechanizmusának alapja a szekvencia specifikusan történő felismerés, az Agrobacterium iaaM szekvenciák pedig nagyon eltérőek még a közeli rokon törzsek esetében is (Galambos 2007), ezért valószínüsíthető volt, hogy ez a konstrukció nem biztosíthat rezisztenciát minden Agrobacterium törzzsel szemben. A szőlő esetében jelentős $A$. vitis $\mathrm{S} 4$ törzzsel szemben - amelynek iaaM szekvenciája nagymértében eltér a többi Agrobacterium törzsétől - a Galambos Anikó (2007) által elkészített pJP17-S4 konstrukció biztosíthat rezisztenciát, melynek hatásosságát kalanchoe koinokulációs és dohány transzformációs kísérletek segítségével bizonyították. Ream és munkatársai (2003) szintén az iaaM és ipt onkogének elhallgattatásához szükséges transzformációval $A$. tumefaciens A348 törzzsel szemben ellenálló alma (Malus domestica) vonalakat, Escobar és munkatársai $(2001,2002)$ pedig az A. tumefaciens 20W-5A, K12, 53-1B törzsekre rezisztens lúdfü (Arabidopsis thaliana), paradicsom (Lycopersicon esculentum) és dió (Juglans regia) növényeket állítottak elö.

A V. amurensis eredetü, tanszéki nemesítésü fajták Agrobacterium rezisztencia vizsgálatai során a 'Korai bíbor' és 'Orpheus' az A. tumefaciens C58 törzzsel szemben; az 'Odysseus' és 'Pannon frankos' az A. tumefaciens C58, A. vitis AT1 és S4 törzsekkel 
szemben bizonyult rezisztensnek. A 'Taurus' mind az 5 Agrobacterium törzzsel szemben egyértelmüen rezisztensnek bizonyult. Szegedi (1981) és munkatársai különböző Vitis genotípusokat teszteltek agrobaktérium fertőzéssel szembeni fogékonyságra. A tesztelt fajták közül a V. riparia cv. 'Portalis' alanyfajtán, a V. amurensis eredetű 'Kunbaráton', valamint a 'Szultán' fehér szőlőn nem képződött tumor az A. tumefaciens és A. vitis törzsekkel történő fertőzés után. Ezt követően a golyvásodással szembeni rezisztenciát kimutatták a $V$. amurensis fajtán és számos hibridjén, továbbá bizonyították Mendeli, domináns öröklődését (Szegedi and Kozma, 1984). Az Agrobacterium-rezisztens szőlő genotípusok, a betegséggel szemben ellenálló fajták létrehozása mellett felhasználhatóak az ellenállóképesség természetének megismerésére; valamint a természetesen előforduló, ismeretlen funkciójú rezisztenciagének izolálása és vizsgálata fontos információkkal szolgálhat a modern, molekuláris alapú nemesítés számára. 


\section{8. ÖSSZEFOGLALÁS}

A sikeres genetikai transzformációs kísérletek alapja a hatékony növény-sejtnövény regenerációs rendszer. Napjaink irodalmát áttekintve elmondhatjuk, hogy a különböző transzformációs eljárásoknál gyakran indulnak ki szomatikus embriókból. A szomatikus embriók indukciójára, valamint a transzgénikus növények regenerációjára többféle eljárás létezik. Különbség mutatkozhat a fajták között, a felhasznált növényi részben, a táptalaj összetételében és a kísérleti körülményekben. A portokokon végzett embriogén kallusz indukciós kísérletekben a tesztelt 12 szőlőfajtából 11 esetben kaptunk embriogén kalluszt. A 'Korai bíbor', 'Odysseus', 'Orpheus' és 'Pannon frankos’ fajtáknál elsőként számolhattunk be sikeres embriogén kallusz indukcióról. A portokon megjelent kallusz embriogén kapacitását növényregenerációval bizonyítottuk.

A portok indukciós kísérletek mellett megkíséreltünk direkt organogenezissel a rügyalapból növényregenerációt elöidézni a 'Richter 110' fajta esetében, azonban ennél a fajtánál ez a módszer nem müködött megfelelő hatékonysággal. Ennek ellenére a módszer alkalmazása azon fajták esetében jelenthet egy lehetséges megoldást génbevitelre, amelyek portok tenyészetein jelenleg nem tudunk embriogén kalluszt létrehozni.

A különböző indukciós kísérletekben nyert embriogén kalluszt fel kell szaporítanunk, hogy megfelelő mennyiségü kiindulási anyag álljon rendelkezésünkre a transzformációs kísérletekhez. Az embriogén tenyészetek fenntartása és felszaporítása azonban számos fajta esetében problémát jelentett. A 'Richter 110' alanyfajta esetében kipróbáltuk, és sikeresen alkalmaztuk az 1,1 mg/l 2,4-D-t és 0,1 mg/l BA-t tartalmazó CPE táptalajt embriogén kallusz felszaporítására. A CPE a Cheé és Pool (1987) által leírt szőlőre optimalizált táptalaj hormonokkal kiegészített változata, valószínüsíthetően más fajtáknál is eredményesen alkalmazható embriogén kallusz felszaporítására.

A növényregeneráció hatékonyságát jelentősen befolyásolja a kiindulási anyag minősége. Az $5 \mu \mathrm{M}$ NOA tartalmú folyékony kultúrák alkalmazásával célunk a kis vakuolumokkal rendelkező, gyorsan osztódó sejtek felszaporítása volt, kísérleteink a 'Richter 110', 'Teleki 5C' és 'Chardonnay' fajták esetében eredményesnek bizonyultak. Ezen kívül a 'Chardonnay' fajta esetében a hormonmentes CP táptalajt is eredményesen alkalmaztuk a regenerációs hatékonyság növelésére. Kísérleteinkben a $\mathrm{CP}$ táptalajt a szintén hormonmentes MS/2 táptalajjal összehasonlítva az embriogén anyag regenerációs idejének hosszában mutatkozott jelentős eltérés a CP táptalaj javára. 
A transzformált és mikroszaporított növények akklimatizációs hatékonyságának növelése érdekében különböző kísérleteket végeztünk el a 'Richter 110' fajta kétrügyes dugványain. Munkánk során háromféle nedvesítö-, és négyféle gyökereztető közeget teszteltünk, valamint kétféle eljárást alkalmaztunk a tenyészedények zárására. A 'Richter 110’ fajta számára a csapvízzel nedvesített perlitben történő gyökereztetés bizonyult a legmegfelelőbbnek, ezért a különböző vektorkonstrukciókkal transzformált növények akklimatizációja során ezt az eljárást alkalmaztuk.

Genetikai transzformációs kísérleteink során sikeresen állítottunk elő lucerna ferritin génnel transzformált 'Richter 110' növényeket az EHA105(pRok2Ferr) és EHA105(pRok2FerrFLAG) vektorkonstrukciók felhasználásával. Agrobacterium rezisztens növények előállítását célzó transzformációs kísérleteinket az EHA101(pTd93virE1) vektorkonstrukció felhasználásával, az Agrobacterium tumefaciens virE1 génjének expresszáltatásával; valamint az EHA101(pJP17) és EHA101(pJP17-S4) vektorkonstrukciók felhasználásával, a géncsendesítés mechanizmusán keresztül kívántuk megvalósítani. A 0,22 mg/l BA használata a szelekciós táptalajban, illetve az abnormális fejlődésű embriók pusztuló gyökérnyaki részének eltávolítása alkalmasnak bizonyult a transzformációs eljárásnak köszönhetően nagy mennyiségben előforduló abnormális fejlődésű transzformált embriók hajtásfejlődésének helyreállítására.

A hat pRok2Ferr transzformáns 'Richter 110' vonal fiziológiai jellemzése során két transzgénikus vonal esetében megnövekedett oxidatív stressz toleranciát tapasztaltunk, ami a lucerna ferritin fehérje szőlőlevelekben kifejtett pozitív hatását valószínüsíti.

Agrobacterium rezisztencia vizsgálataink során a 21 független EHA101(pJP17) vektorral transzformált 'Richter 110' vonal harmada bizonyult egyértelmüen rezisztensnek az A348 törzzsel szemben. Az EHA101(pTd93virE1) vektorral transzformált 'Richter 110' növények csökkent életképessége miatt csak egy Agrobacterium törzzsel tudtuk elvégezni a fertőzéseket, ezért egyértelmű következtetéseket nem tudtunk levonni arra vonatkozólag, hogy ez a vektorkonstrukció alkalmas-e a szőlőben Agrobacterium rezisztencia kialakítására. A tanszéki nemesítésü fajták Agrobacterium rezisztencia vizsgálatai során a 'Korai bíbor' és 'Orpheus' az A. tumefaciens C58 törzzsel szemben; az 'Odysseus' és 'Pannon frankos' az A. tumefaciens C58, A. vitis AT1 és S4 törzsekkel szemben; a ‘Taurus' pedig mind az 5 Agrobacterium törzzsel szemben egyértelmúen rezisztensnek bizonyult. 


\section{SUMMARY}

The avaiability of an effective plant-cell-plant regeneration system is a basic prerequisite of genetic transformation. According to the recently published articles it can be concluded that embryogenic cultures are most frequently used for grapevine transformation experiments. To induce somatic embryos and regenerate transgenic plants different methods are used. Among callus initiation conditions, essential differences are detectable in the medium, genotype and explant of grapevine used for induction. In our embryogenic callus initiation experiments 12 different cultivars were tested, and anther derived embryogenic callus was successfully obtained in 11 genotypes. Moreover, this is the first report on embryogenesis in 'Korai bíbor', 'Odysseus', 'Orpheus' and 'Pannon frankos'. The embryogenic capacity of anther derived callus was confirmed by plant regeneration.

Besides producing embryogenic callus on anthers we have studied direct shoot regeneration from the cells of the base of the bud of 'Richter 110', but its efficiency was low. However, this method might be a potential way for gene transfer in case of cultivars on which anthers embriogenic callus induction has not been solved yet.

The embriogenic callus obtained on anthers should be propagated to have enough starting material for transformation experiments, but the maintanance and propagation of embriogenic callus caused a problem in many case of cultivars. CPE medium proved applicable to propagate embryogenic callus in case of 'Richter 110'. CPE is the medium described by Cheé and Pool (1987) supplemented with 1,1 mg/l 2,4-D and 0,1 mg/l BA, and it might be succesfully used for propagation of embriogenic callus of many other cultivars.

Effectivity of plant regeneration is highly affected by the quality of starting material. Using liquid medium containing $5 \mu \mathrm{M}$ NOA we achieved homogeneous 'Richter 110', 'Teleki 5C' and 'Chardonnay' embryogenic cultures propagated rapidly and contained cells with small vacuoles. Besides, CP medium was successfully used in case of 'Chardonnay' to increase the efficiency of regeneration. Comparing CP medium to MS/2 hormon-free medium we found CP that shortens the time of regeneration.

To improve hardening and transfer of regenerated transgenic grapevine, in vitro grown 'Richter 110 ' plants were multiplied by cutting them into double-node internodes with the whole leaf. In our experiments microcuttings were tested using three different 
moisturing and four rooting media, and for cover of culture vessels two different method were tried. When perlite was used and moisted with tapwater proper rooting of 'Richter $110^{\prime}$ microcuttings was observed, therefore this method was used further to harden transgenic 'Richter 110' plants harbouring the different gene constructions.

We have carried out genetic transformation experiments using EHA105(pRok2Ferr) and EHA105(pRok2FerrFLAG) transformation vectors and have successfully obtained 'Richter 110' plants transformed with alfalfa ferritin gene. In the transformation experiments to introduce enhanced resistance to Agrobacterium, EHA101(pTd93virE1), EHA101(pJP17) and EHA101(pJP17-S4) transformation vectors were used. Overexpressing Agrobacterium VirE1 proteins may provide resistance to Agrobacterium by inhibiting VirE2. Applying EHA101(pJP17) and EHA101(pJP17-S4) vector constructions we aimed to provide Agrobacterium resistance through posttranscriptional gene silencing.

Shoot formation of transformed 'Richter 110' embryos was best restored by using $0,22 \mathrm{mg} / \mathrm{l} \mathrm{BA}$ in the selection medium and cutting the abnormal embryos under the hypocotyl. Applying these methods we observed the recovery of shoot development of embryos that showed developmental disorder due to the transformation process.

For physiological studies 6 pRok2Ferr transgenic lines and the non-transformed 'Richter 110' plants were used. In case of two transgenic lines we found an increased tolerance to oxidative stress effects, which suggests the protective role of ferritin in grapevine leaves.

Agrobacterium resistance of 21 'Richter 110' transgenic lines harbouring EHA101(pJP17) construction were studied, and 1/3 part of the investigated transgenic lines was found to be resistant to Agrobacterium tumefaciens A348 strain. Because the pTd93virE1-transformed plants showed abnormal shoot and leaf morphology accompained by weak growth, we could not say if this gene construction is suitable in grapevine for engineering Agrobacterium resistance. These plants were infected only with one Agrobacterium strain due to propagation problems caused by their abnormal growth. Of the new cultivars bred at our Department 'Korai bíbor' and 'Orpheus' showed resistance to A. tumefaciens C58; 'Odysseus' and 'Pannon frankos' to A. tumefaciens C58, A. vitis AT1 and S4; while 'Taurus' was resistant to all of the five tested Agrobacterium strains. 


\section{KÖSZÖNETNYILVÁNÍTÁS}

Köszönetemet szeretném kifejezni témavezetőimnek Dr. Pedryc Andrzejnek és Dr. Oláh Róbertnek, valamint Dr. Szegedi Ernőnek munkám során nyújtott értékes tanácsaiért.

Köszönöm Hermán Rita, Tóth Vera, Gyurcsáné Millei Ágnes és Bacskainé Papp Anna segítőkészségét, kedvességét.

Köszönettel tartozom a Magyar Tudományos Akadémia Szegedi Biológiai Központ, Növénybiológiai Intézet, a Budapesti Corvinus Egyetem Szőlészeti és Borászati Kutató Intézet (Kecskemét) és a Pécsi Tudomány Egyetem Természettudományi Kar, Biológiai Intézet, Genetika és Molekuláris Biológiai Tanszék munkatársainak önzetlen segítségükért.

Ezúton szeretném megköszönni a Tanszék valamennyi munkatársának segítségét.

Munkánkat a TÁMOP 4. 2. 1./B-09/01/KMR/2010-0005 és az NKTH-OTKA K68053 pályázat támogatta. 


\section{IRODALOMJEGYZÉK}

1. Agüero, C. B., Meredith, C. P. and Dandekar, A. M. 2006. Genetic transformation of Vitis vinifera L. cvs Thomson Seedless and Chardonnay with the pear PGIP and GFP encoding genes. Vitis 45: 1-8.

2. Amar, B. A., Cobanov, P., Boonrod, K., Krczal, G., Bouzid, S., Ghorbel, A. and Reustle, G. M. 2007. Efficient procedure for grapevine embryogenic suspension establishment and plant regeneration: role of conditioned medium for cell proliferation. Plant Cell Rep. 26:1439-1447.

3. Ammirato, P. V. 1983. Embriogenesis. In: Evans, D. A., Sharp, W. R., Ammirato, P. V., Yamada, Y. (eds.) 1983. Handbook of Plant Cell Culture. 1: 82-123. Mc Millen Publishing Company, New York - London.

4. Apel, K. and Hirt, H. 2004. Reactive oxygen species: metabolism, oxidative stress, and signal transduction. Annu. Rev. Plant Biol. 55: 373-399.

5. Babbs, C. E., Pham, J. A. and Coolbaugh, R. C. 1989. Lethal hydroxyl radical production in paraqat treated plants. Plant Physiol. 90: 1267-1270.

6. Baker, C. J. and Orlandi, E. W. 1995. Active oxygen in plant pathogenesis. Ann. Rev. Phytopathol. 33: 299-321.

7. Balla, Gy., Jacob, H. S., Balla, J., Rosenberg, M., Narth, K. and Apple, F. 1992. Ferritin: a cytoprotective antioxidant strategem of endothelium. J. Biol. Chem. 267: 18148-18153.

8. Bartels, D. and Sunkar, R. 2005. Drought and salt tolerance in plants. Crit. Rev. Plant Sci. 21: 1-36.

9. Baulcombe, D. C., Saunders, G. R., Bevan, M. W., Mayo, M. A. and Harrison, B. D. 1986. Expression of biologically-active viral satellite RNA from the nuclear genome of transformed plants. Nature 321: 446-449.

10. Baulcombe, D. 2004. RNA silencing in plants. Nature 2005: 356-363.

11. Berres, R., Otten, L., Tinland, B., Malgarini-Clog, E. and Walter, B. 1992. Transformation of Vitis tisssue by different strain of Agrobacterium tumefaciens containing the T-6b gene. Plant Cell Rep. 11:192-195.

12. Beyer, Y., Imaly, J. and Fridovich, I. 1991. Superoxide dismutases. Prog. Nucl. Acid Res. Mol. Biol. 40: 221-253.

13. Bhatnagar-Mathur, P., Vadez, V. and Sharma, K. K. 2008. Transgenic approaches for abiotic stress tolerance in plants: retrospect and prospects. Plant Cell Rep. 27: 411-424.

14. Bingh, D., Heszky, L., Gyulai, G., Kiss, E. and Csillag, A. 1989. Plant regeneration from callus of Puccinellia clistans (L.). Parl. PCTOC 18: 195-200.

15. Bolhár-Nordenkampf, H. R. and Lechner, E. 1988. Winter stress and clorophyll fluorescence in norway spruce (Picea abies, L., Karst.). In: Lichtenthaler, H. K. (ed.) 1988. Applications of Chlorophyll Fluorescence, Kluwer Academic Publishers, The Netherlands, pp. 173-180. 
16. Bonner, D. M., Haagen-Smit, A. J. and Went, F. W. 1939. Leaf growth hormones. I. A bioassay and saurce for leaf growth factors. Bot. Gaz. 101: 128-144. In: Dudits, D. and Heszky, L. (eds.) 1990. Növénybiotechnológia. Mezőgazdasági Kiadó, Budapest.

17. Bornhoff, B. A. and Harst, M. 2000. Establishment of embryo suspension cultures of grapevines (Vitis L.). Vitis 39: 27-29.

18. Bornhoff, B. A., Harst, M., Zyprian, E. and Töpfer, R. 2005. Transgenic plants of Vitis vinifera cv Seyval blanc. Plant Cell Rep. 24: 433-438.

19. Bouamama, B., Jardak, R., Salem, A. B., Ghorbel, A. and Mliki, A. 2009. Preservation of endangered Tunisian grapevine using embryogenic cultures. Electr. J. Biotechnol. ISSN: 0717-3458. 12: 6-7.

20. Brencic, A., Angert, E. R. and Winans, S. C. 2005. Unwounded plants elicit Agrobacterium vir gene induction and T-DNA transfer: transformed plant cells produce opines yet are tumour free. Mol. Microbiol. 57: 1522-1531.

21. Brisson, N., Paszkowki, J., Penswick, J. R., Gronenborn, B., Potrykus, J. and Hohn, T. 1984. Expression of a bacterial gene in plants by using viral vector. Nature 310: 511514.

22. Burgyán, J. 2006. Virus Induced RNA silencing and suppression: Defence and Counter defence. J. Plant Pathol. 88: 233-244.

23. Burr, T. J., Bazzi, C., Süle, S. and Otten, L. 1998. Crown gall of grape: Biology of Agrobacterium vitis and the development of disease control strategies. Plant Dis. 82: 1288-1297.

24. Cario, G., Tacchini, L., Pogliaghi, G., Anzon, E., Tornasi, A. and Bernelli-Zazzera, A. 1995. Induction of ferritin synthesis by oxidative stress. Transcriptional and posttranslational regulation by expansion of the free iron pool. J. Biol. Chem. 270: 700703.

25. Cersosimo, A., Crespan, M., Paludetti, G. and Altamura, M. 1990. Embryogenesis, organogenesis and plant regeneration from anther culture in Vitis. Acta Hort. 280: 307314.

26. Cheé, R. and Pool, R. M. 1987. Improved inorganic media constituents for in vitro shoot multiplication of Vitis. Sci. Hortic. 32: 85-89.

27. Chia, L. S., Mayfield, C. I. and Thompson, J. E. 1984. Simulated acid rain induces lipid peroxidation and membrane damage in foliage. Plant Cell Environ. 7: 333-338.

28. Christie, P. J. 1997. Agrobacterium tumefaciens T-complex transport apparatus: a paradigm for a new family of multifunctional transporters in Eubacteria. J. Bacteriol. 179: 3085-3094.

29. Colova-Tsolova, V., Perl, A., Krastanova, S., Tsetkov, I. and Atanassov, A. 2001. Genetically engineered grape for disease and stress tolerance. In: Roubelakis-Angelakis, K. A. (ed.) 2001. Molecular Biology \& Biotechnology of the Grapevine. pp. 411-432. Kluwer Academic Publishers, Dordrecht-Boston-London.

30. Coutos-Thevenot, P., Goebel-Tourand, I., Mauro, M. C., Jouanneau, J. P., Boulay, M., Deloire, A. and Guern, J. 1992. Somatic embryogenesis from grapevine cells IImprovement of embryo development by changes in culture conditions. PCTOC 29: 25133. 
31. Coutos-Thévenot, P., Poinssot, B., Bonomelli, A., Yean, H., Breda, C., Buffard, D., Esnault, R., Hain, R., and Boulay, M. 2001. In vitro tolerance to Botrytis cinerea of grapevine 41B rootstock in transgenic plants expressing the stilbene synthase Vst 1 gene under the control of a pathogeninducible PR10 promoter. J. Exp. Bot. 52: 901910.

32. Crossway, A., Dakes, J. V., Irvine, J. M., Ward, B., Knauf, V. C., and Schewmaker, C. K. 1986. Integration of foreign DNA following microinjection of tobacco mesophyll protoplasts. Mol. Gen. Genet. 202: 179-185.

33. Cutanda, M. C., Bouquet, A., Chatelet, P., Lopez, G., Botella, O., Montero, F. J. and Torregosa, L. 2008. Somatic embryogenesis and plant regeneration of Vitis vinifera cultivars 'Macabeo' and 'Tempranillo'. Vitis 47: 159-162.

34. Davey, M. R., Cocking, E. C., Freeman, J., Pearce, N., and Tudor, J. 1980. Transformation of Petunia protoplasts by isolated Agrobacterium plasmids. Plant Sci. Lett. 18: 307-313.

35. Deák, M., Horváth, V. G., Davletova, S., Török, K., Sass, L., Vass, I., Barna, B., Király, Z. and Dudits, D. 1998. Plants ectopically expressing the iron-blinding protein, ferritin are tolerant to oxidative damage and pathogens. Nat. Biotechnol. 17: 192-196.

36. DeBlock, M., Herrera-Estrella, L., Van Montagu, M., Schell, J. and Zambrisky, P. 1984. Expression of foreign genes in regenerated plants and in their progeny. EMBO J. 3: $1681-1689$.

37. Deng, W., Chen, L., Peng, W.-T., Liang, X., Sekiguchi, S., Gordon, M. P., Comai, L. \& Nester, E. W. (1999): VirE1 is a specific molecular chaperone for the exported singlestranded DNA-binding protein VirE2 in Agrobacterium. Mol. Microbiol. 31: 17951807.

38. Dudits, D. and Heszky, L. 1990. Növénybiotechnológia. Mezőgazdasági Kiadó, Budapest. pp. 24-52., 168-201.

39. Ebert, A. and Taylor, H. F. 1990. Assessment of the changes of 2,4dichlorophenoxyacetic acid concentrations in plant tissue culture media in the presence of activated charcoal. PCTOC 20: 165-172.

40. Elstner, E. F. 1982. Oxygen activation and oxygen toxicity. Ann. Rev. Plant Physiol. 33: 73-96.

41. Elstner, E. F. and Osswald, W. 1994. Mechanism of oxygen activation during plant stress pp. 131-154. In: Crawford, R. M. M., Hendry, G. A. F. and Goodman, B. A. (eds.) 1994. Oxygen and environmental stress in plants. The Royal Society of Edinburgh, Edinburgh, Scotland.

42. Escobar, M. A., Civerolo, E. L., Summerfelt, K. R. and Dandekar, A. M. 2001. RNAi-mediated oncogene silencing confers resistance to crown gall tumorigenesis. Proc. Natl. Acad. Sci. 98: 13437-13442.

43. Escobar, M. A., Leslie, C. A., McGranahan, G. H. and Dandekar, A. M. 2002. Silencing crown gall disease in walnut (Juglans regia L.). Plant Sci. 163: 591-597.

44. FAO statistics: http:// faostat.fao.org. 2011.05.14.

45. Flich, C. E., Evans, D. A. and Sharp, W. E. 1983. Organogenesis. In: Evans, D. A., Sharp, W. R., Ammirato, P. W., Yamada, Y. (eds.) 1983. Handbook of Plant Cell Culture 1: 13-81. 
46. Folk, G. és Glits, M. 1993. Kertészeti növénykórtan. Mezőgazda kiadó, Budapest. pp. 264-265.

47. Forgács, I., Zok, A., Novák, E., Pedryc, A. and Oláh, R. 2011. Establishment of grapevine embryogenic suspension culture and induced somatic embryogenesis. 7th international IVCHB symposium. Ghent, Belgium. 133.

48. Foyer, C. H., Descourviéres, P., and Kunert, K. J. 1994. Protection against oxygen radicals: an important defence mechanism studied in transgenic plants. Plant Cell Environ. 17: 507-523.

49. Fromm, F., Taylor, L., and Walbot, V. 1986. Stable transformation of maize after gene transfer by electroporation. Nature 319: 791-793.

50. Galambos, A. 2007. Agrobacterium vitis rezisztencia kialakítása az iaaM szekvencia segítségével. PTE TTK Biológiai Intézet, Genetika és Molekuláris Biológiai Tanszék, Diplomamunka. pp. 7-26.

51. Gambino, G., Ruffa, P., Vallania, R. and Gribaudo, I. 2007. Somatic embryogenesis from whole flowers, anthers and ovaries of grapevine (Vitis spp.). PCTOC 90: 79-83.

52. Gangopadhyay, G., Das, S., Mitra, S. K., Poddar, R., Modak, B. K. and Mukherjee, K. K. 2002. Enhanced rate of multiplication and rooting through the use of coir in aseptic liquid culture media. PCTOC 68: 301-310.

53. Gasser, C. S., and Fraley, R. T. 1989. Genetically engineering plants for crop improvement. Science 244: 1293-1299.

54. Gebhardt, K. and Friedrich, M. 1987. Micropropagation of Calluna vulgaris cv. 'H.E. Beale'. PCTOC 9: 137-145.

55. Gheysen, G., van Montagu, M. and Zambrysky, P. 1987. Integration of Agrobacterium tumefaciens DNA (T-DNA) involves rearrangements of target plant DNA sequences. Proc. Natl. Acad. Sci. USA 84: 6169-6173.

56. Gölles, R., da Camara Machado, A., Minafra, A., Savino, V., Saldarelli, G., Martelli, G. P., Pühringer, H., Katinger, H. and Laimer da Camara Machado, M. 1998. Transgenic grapevines expressing coat protein gene sequences of grapevine fanleaf virus, arabis mosaic virus, grapevine virus A and grapevine virus B. Symp. Int. Sur La Genetique Et L'Amelioration De La Vigne. Montpellier. C3.5.

57. Gray, D. J. and Purohit, A. 1991a. Somatic embriogenesis and development of synthetic seed technology. Crit. Rev. Plant Sci. 10: 33-61.

58. Gray, D. J. and Purohit, A. 1991b. Quiescence and dormancy in somatic embrios. In: Bajaj Y. P. S. (ed.) 1992. Biotechnology in agriculture and forestry. 17: 382-394. Springer-Verlag, Berlin, Germany.

59. Gregory, W. C. 1940. Experimental studies on the cultivation of excised anthers in nutrient solution. Am. J. Bot. 27: 687-692. In: Dudits, D. and Heszky, L. (eds.) 1990. Növénybiotechnológia. Mezőgazdasági Kiadó, Budapest.

60. Gribaudo, I., Restagno, M. and Novello, V. 2003. Vented vessels affect growth rate of in vitro Vitis vinifera cv. Nebbiolo. Acta Hort. 616: 129-133.

61. Gribaudo, I., Gambino, G. and Vallania, R. 2004. Somatic embryogenesis from grapevine anthers: the optimal developmental stage for collecting explants. Am. J. Enol. Vitic. 55(4): 427-430. 
62. Grimsley, N., Hohn, T., Davis, J. W. and Hohn, B. 1987. Agrobacterium-mediated delivery of infectious maize streak virus into maize plants. Nature 325: 177-179.

63. Guellec, V., David, C., Branchard, M. and Tempé, J. 1990. Agrobacterium rhizogenes mediated transformation of grapevine (Vitis vinifera L.). PCTOC 20: 211-215.

64. Haberland, G. 1902. Kulturversuche mit isolierten Pflanzzellen. Sitzwurgsber. Akad. Wiss. Wien, Math-Naturwiss. Ki. 111: 69-92. In: Dudits, D. and Heszky, L. (eds.) 1990. Növénybiotechnológia. Mezőgazdasági Kiadó, Budapest.

65. Hajdukiewicz, P., Svab, Z. and Maliga, P. 1994. The small, versatile pPZP family of Agrobacterium binary vectors for plant transformation. Plant Mol. Biol. 25: 989-994.

66. Halliwell, B. and Gutteridge, J. M. C. 1986. Oxygen free radicals and iron in relation to biology and medicine: some problems and concepts. Arch. Biochem. Biophys. 246: 501-514.

67. Hammond-Kosack, K. E. and Jones, J. D. G. 1996. Resistance gene-dependent plant defense responses. Plant Cell 8: 1773-1791.

68. Hannig, E. 1904. Zur Physiologie pflanlicher Embryonen. I. Über die Kultur von Cruciferen-Embryonen außerhalb des Embryiosacks. Bot. Z. 62: 45-80. In: Dudits, D. and Heszky, L. (eds.) 1990. Növénybiotechnológia. Mezőgazdasági Kiadó, Budapest.

69. Harst, M. 1995. Development of a regeneration protocol for high frequency somatic embriogenesis from explants of grapevines. Vitis 34 (1): 27-29.

70. Harst, M., Bornhoff, B-A., Zyparian, E. and Töpfer, R. 1998. Regeneration and transformation of different explants of Vitis vinifera spp. Symp. Int. Sur La Genetique Et L'Amelioration De La Vigne. Montpellier. C3.2.

71. Harst-Langenbucher, M. and Alleweldt, G. 1993. The effect of different pretreatments on induction of somatic embryogenesis on anthers of grapevine cultivar Riesling. Vitis 32: 1-7.

72. Hébert-Soulé, D., Kikkert, J. K., Smith, F. D., and Reisch, B. I. 1995. Phosphinothricin stimulates somatic embryogenesis in grape (Vitis sp. L.). Plant Cell Rep. 14: 380-384.

73. Hegedüs, A., Janda, T., Horváth, V. G. and Dudits, D. 2008. Accumulation of overproduced ferritin in the chloroplast provides protection against photoinhibition induced by low temperature in tobacco plants. J. Plant Physiol. 165: 1647-1651.

74. Henle, E. S. and Linn, S. 1997. Formation, prevention, and repair of DNA damage by iron/hydrogene peroxide. J. Biol. Chem. 272: 19095-19098.

75. Hideg, É., Oberschall, A., Horváth, V. G.,Vass, I. and Dudits, D. 2000. Enhanced oxidative stress tolerance in transgenic tobacco. Plant Physiology and Biochemistry, Vol. 38. - Supplément: s234., $12^{\text {th }}$ Congress of the Federation of European Societies of Plant Physiology, 2000. August 21-25.

76. Hodges, L. D., Cuperus, J. and Ream, W. 2004. Agrobacterium rhizogenes GALLS Protein Substitutes for Agrobacterium tumefaciens Single-Stranded DNA-Binding Protein VirE2. J. Bacteriol. 186: 3065-3077.

77. Hoekema, A., Hirsh, P. R., Hooykaas, P. J. J. and Schilperoort, R. A. 1983. A binary plant vector strategy based on separation of vir- and T-regions of the Agrobacterium tumefaciens Ti plasmid. Nature 303: 179-181. 
78. Hoffmann, B., Trinh, T. H., Leung, J., Kondorosi A. and Kondorosi E. 1997. A new Medicago truncatula line with superior in vitro regeneration, transformation and symbiotic properties isolated through cell culture selection. Mol. Plant-Microbe Interact. 10: 307-315.

79. Hood, E. E., Gelvin, S. B., Melchers, L. S., and Hoekema, A. 1993. New Agrobacterium helper plasmids for gene transfer to plants. Transgen. Res. 2: 208218.

80. Hooykaas, P. J. J. and Beijersbergen, A. G. M. 1994. The virulence system of Agrobacterium tumefaciens. Annu. Rev. Phytopathol. 32: 157-179.

81. Humann, J., Andrews, S. and Ream, W. 2006. VirE1-mediated resistance to crown gall in transgenic Arabidopsis thaliana. Phytopathology 96: 105-110.

82. Inzé, D., Follin, A., Van Lijsebettens, M., Simoens, C., Genetello, C., Van Montagu, M., and Schell, J. 1984. Genetic analysis of the individual T-DNA genes of Agrobacterium tumefaciens; further evidence that two genes are involved in indole-3-acetic acid synthesis. Mol. Gen. Genet. 194: 265-274.

83. Iocco, P., Franks, T. and Thomas, M. R. 2001. Genetic transformation of major wine grape cultivars of Vitis vinifera L. Transgenic Res. 10: 105-112.

84. Jay-Allemand, C., Capelli, P. and Cornu, D. 1992. Root development of in vitro hybrid walnut microcuttings in a vermiculite-containing gelrite medium. Sci. Hort. 51: 335342 .

85. Jayasankar, S., Gray, D. J. and Litz, R. E. 1999. High frequency somatic embriogenesis and plant regeneration using suspension culture in grapevine (Vitis vinifera L.). Plant Cell Rep. 18: 533-537.

86. Jayasankar, S., Bondada, B. R., Li, Z. and Gray, D. J. 2003. Comparative anatomy and morphology of Vitis vinifera (Vitaceae) somatic embryos from solid- and liquid-culturederived proembryogenic masses. Am. J. Bot. 90 (7): 973-979.

87. Jenes, B. 1999. Közvetlen DNS bevitel növényekbe, egysziküek transzformációja. In: Balázs, E., Dudits, D. (szerk.) Molekuláris növénybiológia szemelvények. Akadémiai Kiadó, Budapest. pp. 627-664.

88. Kado, C. I. 1994. Promiscuous DNA transfer system of Agrobacterium tumefaciens: role of the virB operon in sex pilus assembly and synthesis. Mol. Microbiol. 12: 17-22.

89. Kampfenkel, K. M., van Montagu, M. and Inzé, D. 1995. Effect of iron excess on Nicotiana plumbaginifolia plants. Implications to oxidative stress. Plant Physiol. 107: 725-735.

90. Kasuga, M., Liu, Q., Miura, S., Yamaguchi-Shonozaki, K. and Shinozaki, K. 1999. Improving plant drought, salt and freezing tolerance by gene transfer of a single stress inducible transcription factor. Nat. Biotechnol. 17: 287-291.

91. Kikkert, J. R., Reustle, G. M., Ali, G. S., Wallace, P. W. and Reisch B. I. 1998. Expression of a fungal chitinase in Vitis vinifera L. 'Merlot' and 'Chardonnay' plants produced by biolistic transformation. Symp. Int. Sur La Genetique Et L'Amelioration De La Vigne. Montpellier. C3.4.

92. Kikkert, J. R., Striem, M. J., Vidal, J. R., Wallace, P. G., Barnard, J. and Reisch, B. I. 2005. Long-term study of somatic embryogenesis from anthers and ovaries of twelve grapevine (Vitis sp.) genotypes. In Vitro Cell Dev. Biol. Plant 41: 232-239. 
93. Király, Z., El-Zahaby, H., Gala, A., Abdou, S., Ádám, A. and Barna, B. 1993. Effect of oxygen free radicals on plant pathogenic bacteria and fungi and on some plant diseases, pp. 9-19. In: Mózsik, Gy., Ernerit, I., Fehér, J., Matkovics, B. and Vincze, Á. (eds.) 1993. Oxygen free radicals and scavengers in the natural sciences, Akadémiai Kiadó, Budapest.

94. Koncz, C. and Schell, J. 1986. The promoter of $\mathrm{T}_{\mathrm{L}}$-DNA gene 5 controls the tissuespecific expression of chimaeric genes carried by a novel type of Agrobacterium binary vector. Mol. Gen. Genet. 204: 383-396.

95. Kotte, W. 1922. Kultursuche mit isolierten Wurzelspitzen. Beitr. Allgem. Bot. 2: 413-434. In: Dudits, D. and Heszky, L. (eds.) 1990. Növénybiotechnológia. Mezőgazdasági Kiadó, Budapest.

96. Krastanova, S., Perrin, M., Barbier, P., Demangeat, G., Cornuet, P., Bardonnet, M., Otten, L., Pinck, L. and Walter, B. 1995. Transformation of grapevine rootstocks with the coat protein gene of grapevine fanleaf nepovirus. Plant Cell Rep. 14: 550554 .

97. Krens, F. A., Molendijk, L., Wullems, G. J. and Schilperoort, R. A. 1982. In vitro transformation of plant protoplasts with Ti-plasmid DNA. Nature 296: 72-74.

98. Laibach, F. 1925. Das Taubwerden von Bestandsamen und die künstliche Aufzucht früh absterbender Bastardembryonen. Z. Bot. 17: 417-459. In: Dudits, D. and Heszky, L. (eds.) 1990. Növénybiotechnológia. Mezőgazdasági Kiadó, Budapest.

99. Lamb, C. and Dixon, R. A. 1997. The oxidative burst in plant disease resistance. Annu. Rev. Plant Physiol. Plant Mol. Biol. 48: 251-275.

100. Lee, H., Humann, J. L., Pitrak, J. S., Cuperus, J. T., Parks, T. D., Whistler, C. A., Mok, M. C. and Ream, L. W. 2003. Translation start sequences affect the efficiency of silencing of Agrobacterium tumefaciens T-DNA oncogenes. Plant Physiol. 133: 966-977.

101. Lee, Y-W., Jin, S., Sim, W-S. and Nester, E. W. 1996. The sensing of plant signal molecules by Agrobacterium: genetic evidence for durect recognition of phenolic inducers by the VirA protein. Gene 179: 83-88.

102. LeGall, O., Torregrosa, L., Danglot, Y., Candresse, T. and Bouquet, A. 1994. Agrobacterium mediated genetic transformation of somatic embrios and regeneration of transgenic plants expressing the coat protein of grapevine chrome mosaic nepovirus (GCMV). Plant Sci. 102: 161-170.

103. Legrand, V., Dalmayrac, S., Latché, A., Pech, J-C., Bouzayen, M., Fallot, J., Torregrosa, L., Bouquet, A. and Roustan, J-P. 2003. Constitutive expression of $\mathrm{Vr}$ $E R E$ gene in transformed grapevines confers enhanced resistance to eutypine, a toxin from Eutypa lata. Plant Sci. 164: 809-814.

104. Lessl, M. and Lanka, E. 1994. Common mechanism in bacterial conjugation and Ti mediated T-DNA transfer to plant cells. Cell 77: 321-324.

105. Li, Z., Jayasankar, S. and Gray, D. J. 2001. Expression of a bifunctional green fluorescent protein (GFP) fusion marker under the control of three constitutive promoters and enhanced derivatives in transgenic grape (Vitis vinifera). Plant Sci. 160: 877-887. 
106. Lichtenstein, C. and Draper, J. 1986. Genetic engineering of plants. pp. 67-119. In: Glover, D. M. (ed.) 1995. DNA Cloning: A Practical Approach. Vol. II. IRL Press, Oxford.

107. Linsmaier, E. M. and Skoog, F. 1965. Organic growth factor requirements of tobacco tissue cultures. Physiol. Plant. 18: 100-127.

108. Liu, P. and Nester, E. W. 2006. Indoleacetic acid, a product of transferred DNA, inhibits vir gene expression and growth of Agrobacterium tumefaciens C58. Proc. Natl. Acad. Sci. USA 103: 4658-4662.

109. Lobréaux, S. and Briat, J-F. 1991. Ferritin accumulation and degradation in different organs of pea (Pisum sativum) during development. Biochem. J. 274: 601-606.

110. Lobréaux, S., Hardy, T. and Briat, J-F. 1993. Abscisic acid is involved in the ironinduced synthesis of maize ferritin. EMBO J. 12: 651-657.

111. López-Pérez, A. J., Carreno, J., Martínez-Cutillas, A. and Dabauza, M. 2005. High embriogenyc ability and plant regeneration of table grapevine cultivars (Vitis vinifera L.) induced by activated charcoal. Vitis 44: 79-85.

112. Low, P. and Merida, J. 1996. The oxidative burst in plant defence: function and signal transduction. Physiol. Plant. 96: 533-542.

113. Maillot, P., Kieffer, F. and Walter, B. 2006. Somatic embryogenesis from stem nodal sections of grapevine. Vitis 45: 185-189.

114. Mallyard, M. 1921. Sur le développement des plantules fragmentées. C. R. Soc. Biol., Paris. 84: 770-772. In: Dudits, D. and Heszky, L. (eds.) 1990. Növénybiotechnológia. Mezőgazdasági Kiadó, Budapest.

115. Maróti, M. 1972. Növényi szövettenyésztés. Tank. Kiadó, Bp. In: Dudits, D. and Heszky, L. (eds.) 1990. Növénybiotechnológia. Mezőgazdasági Kiadó, Budapest.

116. Martinelli, L. and Mandolino, G. 1994. Genetic transformation and regeneration of transgenic plants in grapevine (Vitis rupestris S.). Theor. Appl. Genet. 88: 621-628.

117. Martinelli, L. and Gribaudo, I. 2001a. Somatic embriogenesis in grapevine. In: Roubelakis-Angelakis, K. A. (ed.) 2001. Molecular Biology \& Biotechnology of the Grapevine, 327-352. Kluwer Academic Publishers, Dordrecht-Boston-London.

118. Martinelli, L. and Mandolino, G. 2001b. Transgenic grapes (Vitis species). In: Bajaj, Y. P. S. (ed.) 2004. Biotechnology in Agriculture and Forestry Vol. 47, Transgenic Crops II, 325-338. Springer-Verlag, Berlin-Heidelberg.

119. Mauro, M. C., Nef, C. and Fallot, J. 1986. Stimulation of somatic embryogenesis and plant regeneration from anther culture of Vitis vinifera cv. 'Cabernet Sauvignon'. Plant Cell Rep. 5: 377-380.

120. Mauro, M. C., Toutain, S., Walter, B., Pinck, L., Otten, L., Coutos-Thevenot, P., Deloire, A. and Barbier, P. 1995. High efficiency regeneration of grapevine plants transformed with the GFLV coat protein gene. Plant Sci. 112: 97-106.

121. Mauro, M. C., Walter, B., Pinck, L., Valat, L., Barbier, P., Boulay, M. and CoutosThevenot, P. 1998. Analysis of 41B grapevine rootstocks for grapevine fanleaf virus resistance. Symp. Int. Sur La Genetique Et L'Amelioration De La Vigne. Montpellier. C3.6. 
122. McBride, K. E., Sváb, Z., Schaaf, D. J., Hogan, P. S., Stalker, D. M. and Maliga, P. 1995. Amplification of a chimeric Bacillus gene in chloroplasts leads to an extraordinary level of an insecticidal protein in tobacco. BioTechnology 13: 362-365.

123. McCown, B. H. 1988. Adventitous rooting of tissue cultured plants. In: Davis, T. D., Haissig, B. E. and Sankhla, N. (eds.) Adventitious root formation in cuttings. pp. 389302.

124. Miranda, A., Janssen, G., Hodges, L., Peralta, E. G. and Ream, W. 1992. Agrobacterium tumefaciens transfers extremely long T-DNAs by a unidirectional mechanism. J. Bacteriol. 174: 2288-2297.

125. Motoike, S. Y., Skirvin, R. M., Norton, M. A. and Otterbacher, A. G. 2001. Somatic embriogenesis and long term maintenance of embriogenic lines from fox grapes. PCTOC 66: 121-131.

126. Mozsár, J. and Süle, S. 1994. Rapid method for induction of somatic embryogenesis from Vitis riparia. Vitis 33: 245-246.

127. Mozsár, J., Viczián, O., Süle, S. 1998. Agrobacterium-mediated genetic transformation of an interspecific grapevine. Vitis 37: 127-130.

128. Mullins, M. G. and Srinivasan, C. 1976. Somatic embryos and plantlets from an ancient clone of the grapevine (cultivar 'Cabernet sauvignon') by apomixis in vitro. J. Exp. Bot. 27: 1022-1030.

129. Mullins, M. G., Archie Tang, F. C. and Facciotti, D. 1990. Agrobacterium mediated genetic transformation of grapevines: transgenic plants of Vitis rupestris Scheele and buds of Vitis vinifera L. BioTechnology 8: 1041-1045.

130. Murashige, T. and Skoog, F. 1962. A revised medium for rapid growth and bioassays with tobacco tissue cultures. Physiol. Plant. 155: 473-497.

131. Murgia, I. Briat, J-F., Tarantino, D. and Soave, C. 2001. Plant ferritin accumulates in response to photoinhibition but its ectopic overexpression does not protect against photoinhibition. Plant Physiol. Biochem. 39:797-805.

132. Murthy, B. N. S., Murch, S. J. and Saxena, P. K. 1998. Thidiazuron: A potent regulator of in vitro plant morphogenesis. In Vitro Cell Dev. Biol. Plant 34: 267-275.

133. Nakano, M., Sakikabara, T., Watanabe, Y. and Mu, M. 1997. Establishment of embryogenic cultures in several cultivars of Vitis vinifera and Vitis x labruscana. Vitis 36: 141-145.

134. Nam, J., Mysore, K. S., Zheng, C., Knue, M., Matthysse, A. G. and Gelvin, S. B. 1999. Identification of T-DNA tagged Arabidopsis mutants taht are resistant to transformation by Agrobacterium. Mol. Gen. Genet. 261: 429-438.

135. Neumann, F., Schaefer-Ridder, M., Wang, J. and Hofschineider, P. H. 1982. Gene transfer into mouse lyoma cells by electroporation in high electric fields. EMBO J. 1: 841-845.

136. Nitsch, J. P. and Nitsch, C. 1969. Haploid plants from pollen grains. Science 169: 8587.

137. Nowak, J. and Shulaev, V. 2003. Priming for transplant stress resistance in in vitro propagation. In Vitro Cell Dev. Biol. Plant 39: 107-124. 
138. Oberschall, A., Deák, M., Török, K., Sass, L., Vass, I., Kovács, I., Fehér, A., Dudits, D. and Horváth, V. G. 2000. A novel aldose/aldehide reductase protects transgenic plants against lipid peroxidation under chemical and drought stresses. Plant J. 24: 437-446.

139. Oláh, R., Szegedi, E., Ruthner, S. and Korbuly, J. 2003a. Thidiazuron-induced regeneration and genetic transformation of grapevine rootstock varieties. Vitis 42: 133-136.

140. Oláh, R., Szegedi, E., Ruthner, S. and Korbuly, J. 2003b. Optimization of conditions for regeneration and genetic transformation of rootstock- and scion grape varieties. Acta Hort. 603: 491-497.

141. Oláh, R. 2005. A szőlő genetikai transzformációjának módszertani lehetőségei. BCE Kertészettudományi Kar, Genetika és Növénynemesítés Tanszék, Doktori (PhD) értekezés. pp. 54-78.

142. Oláh, R., Zok, A., Pedryc, A., Howard, S. and Kovács, L. G. 2008. Somatic embryogenesis in a broad spectrum of grape genotypes. Sci. Hort. 120: 134-137.

143. Ouf, M. F., Gazar, A. A., Shehata, Z. A., Abdou, El S., Király, Z. and Barna, B. 1993. The effect of superoxide anion on germination and infectivity of wheat stem rust (Puccinia graminis Pers. f. sp. Tritici Eriks. And Henn.) uredospores. Cereal Res. Commun. 21: 31-37.

144. Palauqui, J. C., Elmayan, T., Pollien, J. M. and Vaucheret, H. 1997. Systemic acquired silencing: transgene-specific post-transcriptional silencing is transmitted by grafting from silenced stocks to non-silenced scions. EMBO J. 16: 4738-4745.

145. Peng, M. and Kuc, J. 1992. Peroxidase-generated hydrogen peroxide as a source of antifungal activity in vitro and on tobacco leaf disks. Phytopathology 82: 696-699.

146. Perl, A. and Eshdat, Y. 1998. DNA transfer and gene expression in transgenic grapes. In: Tombs, M. P. (ed.) 1998. Biotechnology and Genetic Engineering Reviews 15: 365386. Intercept Ltd., Andover.

147. Perl, A., Lotan, O., Abu-Abied, M. and Holland, D. 1996. Establishment of an Agrobacterium mediated transformation system for grape (Vitis vinifera L.): the role of antioxidants during grape-Agrobacterium interactions. Nature Biotechnol. 14: 624-628.

148. Perrin, M., Martin, D., Joly, D., Demangeat, G., This, P. and Masson, J. E. 2001. Medium-dependent response of grapevine somatic embryogenic cells. Plant Sci. 161: 107-116.

149. Perrin, M., Gertz, C. and Masson E. J. 2004. High efficiency initation of regenerable emryogenic callus from anther filaments of 19 grapevine genotypes grown worldwide. Plant Sci. 167: 1343-1349.

150. Pino-Sintra, A. 2007. Establishment of embryogenic cultures and plant regeneration in the Portuguese cultivar 'Touriga Nacional' of Vitis vinifera L. PCTOC 88: 253265 .

151. Prince, A. H., Atherton, N. M. and Headry, G. A. F. 1989. Plant under droughtstress generate activated oxygen. Free Rad. Res. Commun. 8: 61-66.

152. Qiagen, G. 2000. Dneasy Plant Mini Kit and Dneasy Plant Maxi Kit Handbook. pp. 1517. 
153. Rajasekaran, K. and Mullins, M. G. 1981. Organogenesis in internode explants of grapevine. Vitis 20: 218-227.

154. Rajasekaran, K., Vine, J. and Mullins, M. G. 1982. Dormancy in somatic embryos and seeds of Vitis: changes in endogenous abscisic acid during embryogeny and germination. Planta 154: 139-144.

155. Ream, L. W., Gordon, M. P. and Nester, E. W. 1983. Multiple mutations in the Tregion of the Agrobacterium tumefaciens tumor-inducing plasmid. Proc. Natl. Acad. Sci. 80: 1660-1664.

156. Reustle, G., Harst, M. and Alleweldt, G. 1995. Plant regeneration of grapevine (Vitis $s p$.) protoplasts isolated from embryogenic tissue. Plant Cell Rep. 15: 238-241.

157. Riggs, C. D. and Bates, G. W. 1986. Stable transformation of tabacco by electroporation: evidence for plasmid concatenation. Proc. Natl. Acad. Sci. USA, 83: 5602-5606.

158. Roberts, A. V., Smith, E. F. and Mottley, J. 1990. The preparation of micropropagated plantlets for transfer to soil without acclimatization. In: Pollard, J. W. and Walker, J. M. (eds.) 1990. Methods in Molecular Biology. Plant Cell and Tissue Culture 6: 314-322. The Humana Press.

159. Roberts, A. V., Smith, E. F, Horan, I., Walker, S., Matthews, D. and Mottely, J. 1994. Stage III techniques for improving water relations and autotrophy in micropropagated plants. In: Lumsden, P. J., Nicholas, J. R. and Davies, W. J. (eds.) 1994. Physiology, Growth and Development Plants in Culture, pp. 314-322. Kluwer Academic Publishers.

160. Roche, T. D., Long, R. D., Sayegh, A. J. and Hennerty, M. J. 1996. Commercial scale photo-autotrophic micropropagation applications in Irish agriculture, horticulture and forestry. Acta Hort. 440: 515- 520.

161. Romero, C., Belles, J. M., Vaya, J. L., Serrano, R. and Culianez, F. A. 1997. Expression of the yeast trehalose-6-phosphate synthase gene in transgenic tobacco plants: pleiotropic phenotypes include drought tolerance. Planta 201: 293-297.

162. Rossi, L., Hohn, B. and Tinland, B. 1996. Integration of complete transferred DNA units is dependent on the activity of virulence E2 protein of Agrobacterium tumefaciens. Proc. Natl. Acad. Sci. USA 93: 126-130.

163. Rugini, E. and Verma, D. C. 1982. Micropropagation of difficult to propagate almond (Prunus amygalus Batsch) cultivar. Plant Sci. Lett. 28: 273-281.

164. Sambrook, J., Fritsch, E. F. and Maniatis, T. 1982. Gel Electrophoresis of DNA In: Molecular cloning - a laboratory manual. New York, Cold Spring Harbor Laboratory Press 6.1-6.62.

165. Sawada, H., Ieki, H. and Matsuda, I. 1995. PCR detection of Ti and Ri plasmids from phytopathogenic Agrobacterium strains. Appl. Environ. Microbiol. 61: 828-831.

166. Scandalios, J. G. 1990. Response of plant antioxidant defense genes to environmental stress. Adv. Genet. 28: 1-41.

167. Schreiber, U., Schliwa, U. and Bilger, W. 1986. Continuous recording of photochemical and nonphotochemical clorophyll fluorescence quenching with a new type of modulation fluorometer. Photosynth. Res. 10: 51-62. 
168. Scorza, R., Cordts, J. M., Ramming, D. W. and Emershad, R. L. 1995. Transformation of grape (Vitis vinifera L.) zygotic-derived somatic embryos and regeneration of transgenic plants. Plant Cell Rep. 14: 589-592.

169. Scorza, R., Cordts, J. M., Gray, D. J., Gonsalves, D., Emershad, R. L. and Ramming, D. W. 1996. Producing transgenic 'Thompson Seedless' grape (Vitis vinifera L.) plants. J. Amer. Soc. Hortic. Sci. 121: 616-619.

170. Sefc, K. M., Ruckenbauer, P. and Regner, F. 1997. Embryogenesis in microspore culture of Vitis subspecies. Vitis 36: 15-20.

171. Sheng, J. and Citovsky, V. 1996. Agrobacterium-plant cell DNA transport: have virulence proteins, will travel. The Plant Cell 8: 1699-1710.

172. Srivastava, S., Chandra, A., Bhatnagar, A., Shrivastava, S. K. and Ansari, N. H. 1995. Lipid peroxidation product, 4-hydroxynonenal and its conjugate with GSH are excellent substrates of bovine lens aldose reductase. Biochem. Biophys. Res. Commun. 217: 741746.

173. Stamp, J. A. and Meredith, C.P. 1988. Somatic embryogenesis from leaves and anthers of grapevine. Sci. Hortic. 35: 235-250.

174. Sundberg, C. D. and Ream, W. 1999. Agrobacterium tumefaciens chaperone-like protein, VirE1, interacts with VirE2 at domains required for single-stranded DNA binding and cooperative interaction. J. Bacteriol. 181: 6850-6855.

175. Sutherland, M. W. 1991. The generation of oxygen free radical during host plant response to infection. Physiol. Mol. Plant Pathol. 39: 79-93.

176. Szegedi, E. 1981. Szőlőfajták Agrobacterium tumefaciens (Smith et Townsend) Conn-el szembeni fogékonysága. Növényvédelem 17: 442-450.

177. Szegedi, E. and Kozma, P. 1984. Studies on the inheritance of resistance to crown gall disease of grapevine. Vitis 23: 121-126.

178. Szegedi, E., Váradi, G. and Otten, L. 1997. Purification of plasmid DNA by an improved electrophoretic protocol. Biotechnol. Techn. 11: 777-779.

179. Szegedi, E., Oberschall, A., Bottka, S., Oláh, R. and Tinland, B. 2001. Transformation of tobacco plants with VirE1 gene derived from Agrobacterium tumefaciens pTiA6 and its effect on crown gall tumor formation. Int. J. Hort. Sci. 7: 54-57.

180. Taylor, J. H. 1950. The duration of differentiation in excised anthers. A. J. Bot. 37: 137-143. In: Dudits, D. and Heszky, L. (eds.) 1990. Növénybiotechnológia. Mezőgazdasági Kiadó, Budapest.

181. Tesniere, C., Torregrosa, L., Pradal, M., Souquet, J., Gilles, C., Santos, J. D., Chatelet, P. and Gunata, Z. 2006. Effects of genetic manipulation of alcohol dehydrogenase levels on the response to stress and the synthesis of secondary metabolites in grapevine leaves. J. Exp. Bot. 57: 91-99.

182. Theil, E. C. 1987. Ferritin: structure, gene regulation, and cellular function in animals, plants and microorganisms. Annu. Rev. Biochem. 56: 289-315.

183. Tinland, B., Schoumacher, F., Gloeckler, V., Bravo-Angel, A. M. and Hohn, B. 1995. The Agrobacterium tumefaciens virulence D2 protein is responsible for precise integration of T-DNA into the plant genome. EMBO J. 14: 3585-3595. 
184. Torregrosa, L. 1998. A simple and efficient method to abtain stable embryogenic cultures from anthers of Vitis vinifera L. Vitis 37: 91-92.

185. Torregrosa, L., Bouquet, A. and Goussard, P. G. 2001. In vitro culture and propagation of grapevine. In: Roubelakis-Angelakis, K. A. (ed.) 2001. Molecular biology \& biotechnology of the grapevine, pp. 281-326. Kluwer Academic Publishers, Dordrecht/Boston/London.

186. Tsvetkov, I., Tsolova, V. and Atanassov, A. 2000. Gene transfer for stress resistance in grapes. Acta Hort. 528 (I): 389-394.

187. Valerii, A. Z., Ilia, V. K. and Leonid, P. T. 2003. Effects of IAA and BA on development of globular, heart- and torpedo-stage embryos from cell suspensions of three grape genotipes. Sci. Hort. 104: 237-247.

188. Vasil, L. K. 1957. Effect of kinetin and giberellin acid on excised anthers of Allium cepa. Phytomorfology. 7: 138-149. In: Dudits, D. and Heszky, L. (eds.) 1990. Növénybiotechnológia. Mezőgazdasági Kiadó, Budapest.

189. Velich, I. (szerk.) 2001. Növénygenetika. pp. 384-406. Mezőgazda Kiadó, Budapest.

190. Vidal, J. R., Kikkert, J. K., Wallace, P. G. and Reisch, B. 2003. High efficiency biolistic co-transformation and regeneration of 'Chardonnay' (Vitis vinifera L.) containing npt-II and antimicrobial peptide genes. Plant Cell Rep. 22: 252-260.

191. Vidal, J. R., Kikkert, J. R., Malnoy, M. A., Wallace, P. G., Barnard, J. and Reisch, B. I. 2006. Evaluation of transgenic 'Chardonnay' (Vitis vinifera) containing magainin genes for resistance to crown gall and powdery mildew. Transgenic Res. 15: 69-82.

192. Vidal, J. R., Rama, J., Taboada, L., Martin, C., Ibanez, M., Segura, A. and GonzálezBenito, M. E. 2009. Improved somatic embryogenesis of grapevine (Vitis vinifera) with focus on induction parameters and efficient plant regeneration. PCTOC 96: 8594.

193. Vilaplana, M. and Mullins, M. G. 1989. Regeneration of Grapevines (Vitis spp.) in vitro: Formation of adventitious buds on hypocotils and cotyledons of somatic embryos. J. Plant Physiol. 134: 413-419.

194. Vile, G. F. and Tyrrell, R. M. 1993. Oxidative stress resulting from ultraviolet a irradiation of human skin fibroblasts leads to a heme oxygenase-dependent increase in ferritin. J. Biol. Chem. 268: 14678-14681.

195. Viss, W. J., Pitrak, J., Humann, J., Cook, M., Driver, J. and Ream, W. 2003. Crowngall-resistant transgenic apple trees that silence Agrobacterium tumefaciens oncogenes. Mol. Breed. 12: 283-295.

196. Vivier, M. A. and Pretorius, I. S. 2000. Genetic improvement of grapevine: Tailoring grape varieties for the third millennium - a review. S. Afr. Enol. Vitic. 21 (Spec. issue): 5-26.

197. Voinnet, O., Vain, P., Angell, S. and Baulcombe, D. C. 1998. Systemic spread of sequence-specific transgene RNA degradation in plants is initiated by localized introduction of ectopic promoterless DNA. Cell 95: 177-187.

198. Waters, V. and Guiney, D. G. 1993. Processes at the nick region link conjugation, TDNA transfer and rolling circle replication. Mol. Microbiol. 9: 1123-1130.

199. Weising, K., Schell, J. and Kahl, G. 1988. Foreign genes in plants: transfer, structure, expression and applications. Annu. Rev. Genet. 22: 421-477. 
200. Weising, K. and Kahl, G. 1996. Natural genetic engineering of plant cells: the molecular biology of crown gall and hairy root disease. World J. Microbiol. \& Biotechnol. 12: 327-351.

201. Winans, S. C. 1992. Two-way chemical signaling in Agrobacterium-plant interactions. Microbiol. Rev. 56: 12-31.

202. Xue, B., Ling, K. S., Reid, C. L., Krastanova, S., Sekiya, M., Momol, E. A., Süle, S., Mozsár, J., Gonsalves, D. and Burr, T. J. 1999. Transformation of five rootstocks with plant virues genes and virE2 gene from Agrobacterium tumefaciens. In Vitro Cell Dev. Biol. Plant 35: 226-231.

203. Yang, X. M., Cao, Z. Y., An, L. Z., Wang, Y. M. and Fang, X. W. 2006. In vitro tetraploid induction via colchicine treatment from diploid somatic embryos in grapevine (Vitis vinifera L.). Euphytica 152: 217-224.

204. Zaenen, J., van Larebeke, N., Tenchy, H., and Schell, J. 1974. Supercoiled circular DNA in crown gall inducing Agrobacterium strains. J. Mol. Biol. 86: 109-127.

205. Zok, A., Oláh, R., Hideg, É., Horváth, V. G., Kós, B. P., Majer, P., Váradi, G. and Szegedi E. 2009a. Effect of Medicago sativa ferritin gene on stress tolerance in transgenic grapevine. PCTOC 100: 339-344.

206. Zok, A., Kós, B. P., Hideg, É., Váradi, G., Báló, B., Szegedi, E., Horváth, V. G. and Oláh, R. 2009b. Towards the production of stress tolerant grapevine cultivars. Acta Hort. 839: 651-657.

207. Zupan, J. R. and Zambryski, P. 1995. Transfer of T-DNA from Agrobacterium to the plant cell. Plant Physiol. 107: 1041-1047. 